UNIVERSIDADE DE SÃO PAULO

FACULDADE DE ZOOTECNIA E ENGENHARIA DE ALIMENTOS

EVELISE ANDREATTA

Avaliação da qualidade dos queijos Minas Frescal e tipo Mussarela produzidos com leite contendo diferentes níveis de células somáticas 


\section{EVELISE ANDREATTA}

\section{Avaliação da qualidade dos queijos Minas Frescal e tipo Mussarela produzidos com leite contendo diferentes níveis de células somáticas}

Tese apresentada à Faculdade de Zootecnia e Engenharia de Alimentos da Universidade de São Paulo, como parte dos requisitos para a obtenção do Título de Doutor em Zootecnia.

Área de Concentração: Qualidade e Produtividade Animal

Orientador: Prof. Dr. Carlos Augusto Fernandes de Oliveira 


\section{FICHA CATALOGRÁFICA}

preparada pela

Biblioteca da Faculdade de Zootecnia e Engenharia de Alimentos da Universidade de São Paulo

\begin{tabular}{|c|c|}
\hline \multirow{11}{*}{ A557a } & Andreatta, Evelise \\
\hline & Avaliação da qualidade dos queijos Minas Frescal e tipo \\
\hline & $\begin{array}{l}\text { Mussarela produzidos com leite contendo diferentes níveis de } \\
\text { células somáticas / Evelise Andreatta. }\end{array}$ \\
\hline & Pirassununga, 2006. \\
\hline & $110 \mathrm{f}$. \\
\hline & Tese (Doutorado) -- Faculdade de Zootecnia e Engenharia \\
\hline & de Alimentos - Universidade de São Paulo. \\
\hline & Departamento de Engenharia de Alimentos. \\
\hline & Área de Concentração: Qualidade e Produtividade Animal. \\
\hline & Orientador: Prof. Dr. Carlos Augusto Fernandes de Oliveira. \\
\hline & Unitermos: 1. Queijo fresco 2. Queijo de massa filada \\
\hline
\end{tabular}


Aos meus pais, Maria Salete e Elvio,

pelas lições de vida transmitidas em sutis atitudes,

que estarão presentes durante toda a minha jornada;

Aos meus irmãos, Viviane, Elvis Jhocarle e Elvio Jhefferson

pela amizade, carinho e inesgotáveis lembranças

de pequenos fatos que hoje representam muito;

Ao meu noivo Matheus,

pela paciência, otimismo, amor a mim concedido,

atitudes sensatas e naturais que despertam minha admiração

e o meu amor a todo momento;

Com todo amor e carinho

DEDICO 


\section{AGRADECIMENTOS}

Ao Prof. Dr. Carlos Augusto Fernandes de Oliveira, que admiro muito, pelos seus ensinamentos transmitidos, sua confiança em mim depositada, sua valiosa compreensão, sinceridade e honestidade. Muito obrigada!

À Fundação de Amparo à Pesquisa do Estado de São Paulo pela concessão da bolsa de doutorado e pelo apoio financeiro para a realização desta pesquisa.

À Faculdade de Zootecnia e Engenharia de Alimentos, Campus de Pirassununga - USP, pela oportunidade oferecida para a realização deste curso.

Ao Prof. Dr. Marcos Veiga dos Santos pela confiança a mim concedida e empréstimo do laboratório.

Ao Prof. Dr. César Gonçalves de Lima pelo auxílio nas análises estatísticas.

As Profas. Dras. Elisabeth Maria Macedo Viegas e Catarina Abdala Gomide, e Prof. Dr.

Paulo José do Amaral Sobral, pela facilitação no uso de seus respectivos laboratórios.

À Conceição por sua compreensão, competência e amabilidade em todos os momentos estressantes de um pós-graduando.

À querida amiga Roice Eliana Rosim por sua paciência, compreensão, bondade, carinho e essencial ajuda nas análises laboratoriais.

Às colegas e amigas Helena Fagundes, Eliana Tessari e Andrezza Fernandes pela ajuda, compreensão e carinho a mim concedido.

Às minhas queridas e amadas estagiárias, Marina, Camila, Thaís, Natália e Beatriz pela contribuição na parte prática do experimento e por compartilharmos momentos de companheirismo e descontração. 
Ao Fabinho, Oswaldo e Evanilson pela facilitação e ajuda incondicional nos processamentos.

À eterna amiga Andréa Luciana dos Santos por sua dedicação, fé, força de vontade, companheirismo, alto astral, carinho e palavras de conforto nos momentos mais tumultuados.

Aos graduandos que me ajudaram no experimento.

À Ana Mônica, Rose, Rosilda e Apolinário pela facilitação e auxílio nas análises laboratoriais.

À Lucinéia, Adriana e Camila pela ajuda nas análises.

À Tânia Andreotti e ao Prof. Marcelinho pela compreensão, ajuda e hospitalidade durante os três anos de alojamento.

A toda a família do meu noivo pelo carinho, compreensão, apoio e hospitalidade.

A minha avó Ignez, tios Cláudio, Cristina, Dolores e Dorinho, e demais familiares pelo amor que sentem por mim e presença constante em minha vida.

Aos funcionários do setor de gado de leite pela ajuda e compreensão durante o experimento.

Aos professores e funcionários dos departamentos de Zootecnia e Engenharia de Alimentos, pela amizade e convívio durante todos esses anos.

Aos colegas do curso de pós-graduação, pela agradável convivência.

A todos aqueles que, direta ou indiretamente, contribuíram para a realização deste trabalho o meu mais profundo agradecimento. 


\section{RESUMO}

ANDREATTA, E. Avaliação da qualidade dos queijos Minas Frescal e tipo Mussarela produzidos com leite contendo diferentes níveis de células somáticas, 2006. 110f. Tese (Doutorado) - Faculdade de Zootecnia e Engenharia de Alimentos, Universidade de São Paulo, Pirassununga, 2006.

O presente estudo teve por finalidade avaliar os efeitos da contagem de células somáticas (CCS) no leite cru (nos níveis de 100-200.000, 400-500.000 e >800.000 céls./mL) sobre as características físicas, químicas, microbiológicas, sensoriais e funcionais dos queijos Minas Frescal e tipo Mussarela. Utilizou-se um delineamento experimental em parcelas subdivididas em blocos, considerando-se a contagem de células somáticas como efeito principal, os dias de análise como subparcelas e os processamentos como blocos. Cada tipo de leite foi obtido da ordenha de animais previamente selecionados de acordo com o nível de células somáticas. As etapas de elaboração dos queijos incluíram a pasteurização do leite (65ำ C, 30 minutos), adição de cloreto de cálcio, fermento (para a Mussarela) e coalho, coagulação e obtenção do coágulo, dessoragem, salga na massa, filagem, moldagem, salga na salmoura (para a Mussarela), e embalagem dos produtos. Os queijos foram mantidos em B.O.D. a $4{ }^{\circ} \mathrm{C}$ e avaliados nos dias 2, 9, 16, 23 e 30 após a fabricação. A seqüência de elaboração dos queijos Minas e tipo Mussarela foi repetida 5 e 3 vezes, respectivamente, para cada tratamento. As análises realizadas nos queijos foram: $\mathrm{pH}$, acidez, percentuais de gordura, matéria seca (MS), cinzas, nitrogênio total (NT), nitrogênio não protéico (NNP), nitrogênio não caseinoso (NNC), índice de proteólise, ácidos graxos livres (AGL), textura, avaliação sensorial, propriedades funcionais (capacidade de derretimento a $107^{\circ} \mathrm{C}$ e percentual de óleo livre somente no queijo tipo Mussarela), contagem de mesófilos, psicrotróficos e número mais provável a 35 e $45{ }^{\circ} \mathrm{C}$. No queijo Minas Frescal, não houve interação entre CCS e dias de armazenamentos nas avaliações físico-químicas, microbiológicas, funcionais e índice de lipólise, porém houve efeito significativo $(\mathrm{P}<0,05)$ para índices de proteólise e profundidade da proteólise. Já para mesófilos, psicrotróficos, acidez, matéria seca, firmeza e ácidos graxos livres houve efeito significativo $(\mathrm{P}<0,05)$ ao avaliar dias de armazenamento. A avaliação sensorial, no primeiro dia de análise, não apresentou diferença significativa nos atributos, porém o queijo de alta CCS (> 800.000 céls./mL) diferiu dos demais no dia 30, em que recebeu menor nota em todas as características. No queijo tipo Mussarela, houve interação entre CCS e dias de armazenamento apenas para a capacidade de derretimento, resultando em 
aumento do derretimento no decorrer do tempo. Para as características de $\mathrm{pH}$, ácidos graxos livres, índices de proteólise, extensão e profundidade da proteólise, mastigabilidade e elasticidade houve efeito significativo $(\mathrm{P}<0,05)$ para dias de armazenamento. Entre os atributos avaliados na sensorial, apenas a aparência apresentou diferença entre tratamentos. O rendimento dos queijos, Minas frescal e tipo Mussarela, não foram influenciados pela quantidade de células somáticas dos leites. Os resultados do trabalho indicaram que o leite destinado à fabricação dos queijos Minas e tipo Mussarela deve apresentar CCS até 400500.000 céls./mL, de maneira a evitar alterações na qualidade dos produtos ao longo do período de armazenagem.

Palavras-chave: queijo fresco; queijo de massa filada; análises; CCS; mastite. 


\section{ABSTRACT}

ANDREATTA, E. Evaluation of Minas Frescal and Mozzarella type cheeses manufactured from milk containing different somatic cell counts, 2006. 110p. Thesis (Doctorate) - Faculdade de Zootecnia e Engenharia de Alimentos, Universidade de São Paulo, Pirassununga, 2006.

The aim of the present study was to evaluate the effect of somatic cells counts (SCC) in raw milk (at levels of 100-200,000, 400-500,000 and 800,000 cells./mL) on physical, chemical, microbiological, sensorial and functional characteristics of Minas frescal and Mozzarella type cheeses. A completely randomized block design was used, considering SCC as the main effect, the days of analysis as sub parcels and the processing batches as the blocks. Each type of milk was obtained from cows previously selected according to its individual SCC. The manufacture of cheeses included: pasteurization of milk $\left(65^{\circ} \mathrm{C}, 30\right.$ minutes), addition of calcium chloride, starter culture (for Mozzarella) and rennet, coagulation and separation of the curd, whey drainage, salting (for Minas cheese), stretching of the curd, kneading and salting in brine (for Mozzarella), and packing the products. The cheeses were stored in a B.O.D. oven at $4^{\circ} \mathrm{C}$ and evaluated on days 2, 9, 1623 and 30 after the manufacture. The sequence of elaboration of the Minas frescal and Mozzarella cheeses was repeated 5 and 3 times, respectively, for each treatment. The analyses carried out in the cheeses were: $\mathrm{pH}$, acidity, percentages of fat, dry matter (DM), ashes, total nitrogen (NT), non-protein-nitrogen (NPN), non-casein nitrogen (NCN), proteolysis, free fatty acids (FFA), texture, sensorial evaluation, functional properties (melting capacity the $107{ }^{\circ} \mathrm{C}$ and percentage of free oil - only in the cheese Mozzarella), mesophile and psychrotrophic counts and the most probable number at 30 and $45^{\circ} \mathrm{C}$. For Minas frescal cheese, no interaction was found between SCC and days of storage when considering the data on chemical, physical, microbiological, functional and lipolysis index. However, a significant effect $(\mathrm{P}<0.05)$ was observed for proteolysis and depth of proteolysis. For mesophiles, psychrotrophics, acidity, dry matter, firmness and free fatty acids, there was a significant effect $(\mathrm{P}<0.05)$ for days of storage. The sensorial evaluation made on the first day of analysis did not present significant differences for all attributes. However, the Minas cheese made with high SCC (800,000 cells/mL) differed on day 30, when it received worse grades for all the attributes. For the Mozzarella cheese, an interaction between SCC and days of storage was observed only for the melting capacity, which resulted in an increment of the melting along the time of storage. The parameters of $\mathrm{pH}$, free fatty acid, proteolysis, extension and depth of proteolysis, springiness and elasticity had significant 
effect $(\mathrm{P}<0.05)$ for days of storage. Amongst the attributes evaluated in the sensorial, only the appearance presented difference between treatments. The yield of Minas frescal and Mozzarella cheese was not influenced by the amount of somatic cells in the original milk. Results indicated that milk used for the manufacture of Minas frescal and Mozzarella cheeses should present SCC up to $400-500,000$ cells $/ \mathrm{mL}$, in order to avoid quality changes in those products during storage.

Keywords: fresh cheese; stretched curd cheese; analysis; SCC; mastitis. 


\section{LISTA DE FIGURAS}

Figura 1 - Contagem de células somáticas no leite utilizado para fabricação dos lotes dos queijos Minas Frescal (a) e tipo Mussarela (b)........................ 37

Figura 2 - Amostras de leite para confirmação do nível de células somáticas...........

Figura 3 - Tratamento térmico do leite utilizado como matéria prima (65으으.

Figura 4 - $\quad$ Etapas de fabricação do queijo Minas Frescal..

Figura 5 - $\quad$ Repouso após adição de fermento.

Figura 6 - $\quad$ Etapas de fabricação do queijo tipo Mussarela..

Figura 7 - Curva de calibração padrão para análise de AGL dos queijos.

Figura 8 - Análise Microbiológica do queijo.

Figura 9 - Avaliação Sensorial do queijo Minas Frescal..

Figura 10 - Texturômetro.

Figura 11 - Esquema ilustrativo da análise da capacidade de derretimento......

Figura 12 - Avaliação de mesófilos e psicrotróficos em função dos dias de armazenamento.

Figura 13 - Avaliação da acidez em função da quantidade de células somáticas dos queijos Minas Frescal.

Figura 14 - Avaliação da acidez e matéria seca dos queijos Minas Frescal em função dos dias de armazenamento.

Figura 15 - Evolução do índice de proteólise dos queijos durante o armazenamento. ( ) A: 100-200.000 céls./mL; ( $\square$ ) B: 400-500.000 céls./mL; (o) C: > 800.000 céls./mL

Figura 16 - Evolução da extensão da proteólise dos queijos durante o armazenamento. ( ) A: 100-200.000 céls./mL; ( $\square$ ) B: 400-500.000 céls./mL; (o) C: > 800.000 céls./mL.

Figura 17 - Avaliação da firmeza do queijo Minas Frescal em função dos dias de armazenamento.

Figura 18 - Rendimento bruto e ajustado dos queijos, de acordo com os níveis de células somáticas. A: 100.000-200.000 céls./mL; B: 400.000-500.000 céls./mL; C: > 800.000 céls./mL).

Figura 19 - Evolução da contagem de psicrotróficos em função dos dias de armazenamento.

Figura 20 - Evolução da concentração de AGL dos queijos tipo Mussarela em função dos dias de armazenamento.

Figura 21 - Evolução do índice da proteólise dos queijos tipo Mussarela em função dos dias de armazenamento. 
Figura 22 - Evolução dos índices de extensão e profundidade da proteólise dos queijos tipo Mussarela em função dos dias de armazenamento.

Figura 23 - Avaliação da capacidade de derretimento durante o armazenamento. ( $\diamond$ ) A: 100-200.000 céls./mL; ( $\square$ ) B: $400-500.000$ céls./mL; (o) C: > 800.000 céls./mL...............................................................................

Figura 24 - Valores de elasticidade e mastigabilidade dos queijos tipo Mussarela em função dos dias de armazenamento.

Figura 25 Rendimento bruto e ajustado do queijo tipo Mussarela produzido com diferentes níveis de CS. A: 100.000-200.000 céls./mL; B: 400.000500.000 céls./mL e C: > 800.000 céls/mL 


\section{LISTA DE QUADROS}

Quadro 1 - $\quad$ Resumo das análises laboratoriais executadas no experimento............... 38

Quadro 2 - $\quad$ Fluxograma de fabricação do queijo Minas Frescal................................. 42

Quadro 3 - $\quad$ Fluxograma de fabricação do queijo tipo Mussarela................................. 45

Quadro 4 - Ficha para Avaliação da Aparência......................................................... 50

Quadro 5 - Ficha utilizada na Avaliação Sensorial dos Queijos para aroma, sabor, textura e aceitação global.................................................................... 51 


\section{LISTA DE TABELAS}

Tabela 1 - Composição físico-química do leite cru, utilizado na fabricação de queijo Minas Frescal, de acordo com a contagem de células somáticas (CCS).

Tabela 2 - $\quad$ Análise microbiológica do leite $\mathrm{cru}^{1}$, utilizado na fabricação de queijo Minas Frescal, de acordo com a contagem de células somáticas (CCS).

Tabela 3 - Valores de acidez e pH do leite pasteurizado ${ }^{1}$, utilizado na fabricação de queijo Minas Frescal, de acordo com a contagem de células somáticas (CCS).

Tabela 4 - $\quad$ Análise microbiológica do leite pasteurizado ${ }^{1}$, utilizado na fabricação de queijo Minas Frescal, de acordo com a contagem de células somáticas (CCS)

Tabela 5 - Resultados da análise físico-química do soro ${ }^{1}$, de acordo com a contagem de células somáticas (CCS), dos processamentos de queijo Minas.

Tabela 6 - Resultados da análise microbiológica do queijo Minas frescal ${ }^{1}$, de acordo com a contagem de células somáticas (CCS) do leite cru*...

Tabela 7 - Resultados das análises físico-químicas do queijo Minas Frescal $^{1}$, de acordo com a contagem de células somáticas (CCS) no leite cru.

Tabela 8 - Valores do índice de proteólise, extensão e profundidade da proteólise do queijo Minas Frescal, de acordo com a contagem de células somáticas (CCS) no leite $\mathrm{cru}^{1}$.

Tabela 9 - Concentrações de ácidos graxos livres (AGL) do queijo Minas Frescal, de acordo com a contagem de células somáticas (CCS) do leite cru.......

Tabela 10 - Valores de firmeza do queijo Minas frescal ${ }^{1}$, de acordo com a contagem de células somáticas (CCS) do leite cru.

Tabela 11 - Valores de aroma, sabor, textura, aparência e aceitação global do queijo Minas frescal ${ }^{1}$, de acordo com a contagem de células somáticas (CCS).

Tabela 12 - Valores de densidade, acidez, pH e índice crioscópico (IC), gordura, proteína, lactose, sólidos totais (ST) e sólidos não gordurosos (SNG) do leite cru, utilizado na fabricação de queijo tipo Mussarela, de acordo com a contagem de células somáticas (CCS).

Tabela 13 - Análise microbiológica do leite cru, utilizado na fabricação de queijo tipo Mussarela, de acordo com a contagem de células somáticas (CCS).

Tabela 14 - Valores de acidez e pH do leite pasteurizado, utilizado na fabricação de queijo tipo Mussarela, de acordo com a contagem de células somáticas (CCS) 
Tabela 15 - Análise microbiológica do leite pasteurizado, utilizado na fabricação de queijo tipo Mussarela, de acordo com a contagem de células somáticas (CCS).

Tabela 16 - Percentuais de gordura, umidade, sólidos totais (ST) e sólidos não gordurosos (SNG) do soro, resultante da fabricação de queijo tipo Mussarela, de acordo com a contagem de células somáticas (CCS)........

Tabela 17 - Análise microbiológica do queijo tipo Mussarela, de acordo com a contagem de células somáticas (CCS).

Tabela 18 - Valores de $\mathrm{pH}$, acidez, percentuais de gordura, gordura na base seca (GBS), proteína total (PT), matéria seca (MS) e óleo livre do queijo tipo Mussarela, de acordo com a contagem de células somáticas (CCS) no leite cru.

Tabela 19 - Concentrações de ácidos graxos livres (AGL) do queijo tipo Mussarela, de acordo com a contagem de células somáticas (CCS) do leite cru.

Tabela 20 - Índices de proteólise, profundidade e extensão da proteólise do queijo tipo Mussarela ${ }^{1}$, de acordo com a contagem de células somáticas (CCS) no leite cru.....

Tabela 21 - Percentuais da capacidade de derretimento do queijo tipo Mussarela, de acordo com a contagem de células somáticas (CCS) do leite cru.......

Tabela 22 - Valores de firmeza, elasticidade e mastigabilidade do queijo tipo Mussarela, de acordo com a contagem de células somáticas (CCS) no leite cru

Tabela 23 - Valores de aroma, sabor, textura, aparência e aceitação global do queijo tipo Mussarela, de acordo com a contagem de células somáticas (CCS). 


\section{LISTA DE ABREVIATURAS E SIGLAS}

\begin{tabular}{|c|c|}
\hline AGL & Ácidos Graxos Livres \\
\hline ANUALPEC & Anuário da Pecuária Brasileira \\
\hline AOAC & Association of Official Analitycal Chemists \\
\hline APHA & American Public Health Association \\
\hline B.O.D. & Biologic Oxigen Demand \\
\hline $\mathrm{C}$ & Caseína \\
\hline $\mathrm{Ca}$ & Cálcio \\
\hline CCS & Contagem de Células Somáticas \\
\hline céls. & Células \\
\hline $\mathrm{cm}$ & Centímetros \\
\hline C.D. & Capacidade de Derretimento \\
\hline CS & Células Somáticas \\
\hline $\mathrm{CV}$ & Coeficiente de Variação \\
\hline $\mathrm{C}_{4}$ & Cadeia com quatro Carbonos \\
\hline $\mathrm{C}_{8}$ & Cadeia com oito Carbonos \\
\hline DP & Desvio Padrão \\
\hline EPM & Erro Padrão da Média \\
\hline ESALQ & Escola Superior de Agronomia Luiz de Queiroz \\
\hline EUA & Estados Unidos da América \\
\hline $\mathrm{f}$ & Folhas \\
\hline FZEA & Faculdade de Zootecnia e Engenharia de Alimentos \\
\hline g & Gramas \\
\hline GBS & Gordura na Base Seca \\
\hline glm & General Linear Model \\
\hline h & Horas \\
\hline HTST & High Temperature Short Time \\
\hline IC & Índice Crioscópico \\
\hline IDF & International Dairy Federation \\
\hline IFT & Institute of Food Technologists \\
\hline
\end{tabular}




\begin{tabular}{|c|c|}
\hline $\mathrm{kg}$ & Quilograma \\
\hline $\mathrm{L}$ & Litros \\
\hline LANARA & Laboratório Nacional de Referência Animal \\
\hline Log & Logaritmo \\
\hline meq & Miliequivalente \\
\hline MGGL & Membrana de gotículas de gordura do leite \\
\hline $\mathrm{mL}$ & Mililitro \\
\hline $\mathrm{mm}$ & Milímetro \\
\hline MS & Matéria seca \\
\hline $\mathrm{N}$ & Normalidade \\
\hline $\mathrm{n}$. & Número \\
\hline $\mathrm{NaOH}$ & Hidróxido de Sódio \\
\hline $\mathrm{nm}$ & Nanômetro \\
\hline NMP & Número Mais Provável \\
\hline NNC & Nitrogênio Não Caseinoso \\
\hline NNP & Nitrogênio Não Protéico \\
\hline NT & Nitrogênio Total \\
\hline $\mathrm{P}$ & Probabilidade \\
\hline PB & Proteína Bruta \\
\hline PCA & Plate Count Agar; Ágar para Contagem em Placas \\
\hline $\mathrm{pH}$ & Potencial Hidrogeniônico \\
\hline proc & Procedimento \\
\hline PV & Proteína Verdadeira \\
\hline $\mathrm{R}$ & Rendimento Bruto \\
\hline Raj & Rendimento Ajustado \\
\hline Rpm & Rotações por minuto \\
\hline SAS & Statistical Analysis System \\
\hline SMS & Stable Micro Systems \\
\hline SNG & Sólidos Não Gordurosos \\
\hline$s p$ & Espécie \\
\hline ST & Sólidos Totais \\
\hline TCA & Ácido Tricloroacético \\
\hline Тec & Tecnal \\
\hline
\end{tabular}


TPA

UFC

UHT

US\$

USP

V.

Texture Profile Anaysis; Análise do Perfil de Textura

Unidade Formadora de Colônia

Ultra High Temperature

Dólares

Universidade de São Paulo

Volume 


\section{LISTA DE SÍMBOLOS}

\begin{tabular}{ll}
$\alpha$ & Alfa \\
$\beta$ & Beta \\
${ }^{\circ}$ & Graus \\
${ }^{\circ} \mathrm{C}$ & Graus Celsius \\
${ }^{\circ} \mathrm{D}$ & Graus Dornic \\
${ }^{\circ} \mathrm{H}$ & Graus Hortvert \\
$=$ & Igual \\
${ }^{\circledR}$ & Marca Registrada \\
$>$ & Maior \\
\pm & Mais ou Menos \\
$<$ & Menor \\
, & Minutos \\
$\%$ & Porcentagem \\
\hline & Segundos
\end{tabular}




\section{SUMÁRIO}

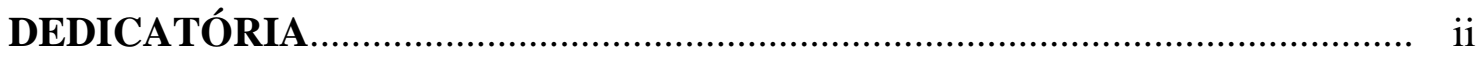

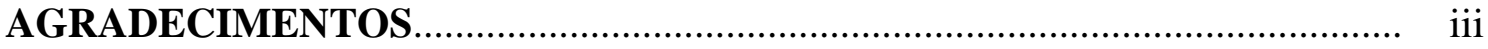

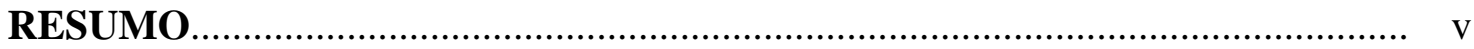

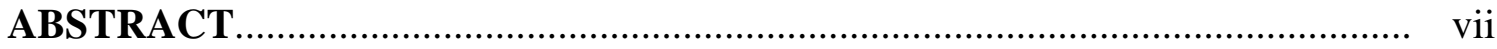

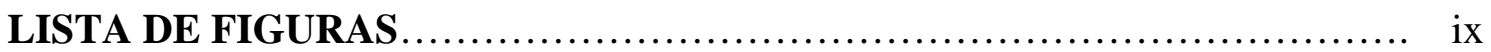

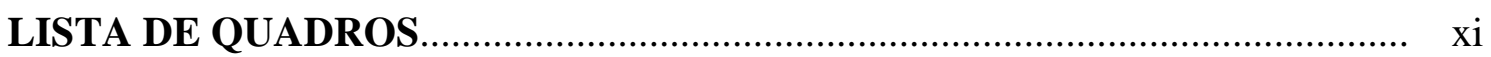

LISTA DE TABELAS................................................................................ xii

LISTA DE ABREVIATURAS E SIGLAS................................................. xiv

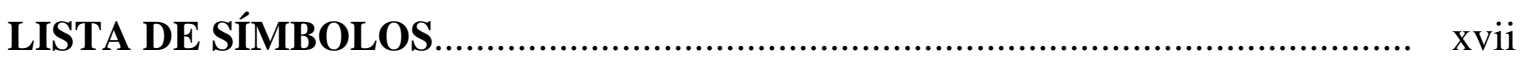

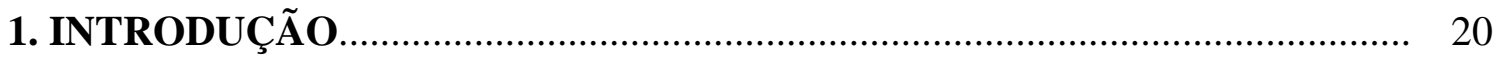

2. REVISÃO DA LITERUATURA............................................................. 23

2.1 Considerações Gerais sobre Mastite e Contagem de Células Somáticas no Leite.

2.2 Efeitos da Mastite sobre a Composição do Leite............................................. 24

2.3 Efeitos da Mastite sobre a Microbiologia do Leite......................................... 28

2.4 Efeitos da Mastite sobre a Qualidade de Produtos Lácteos............................ 29

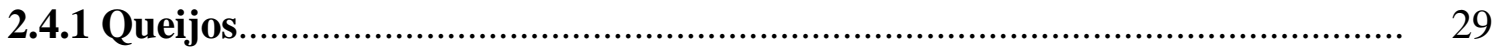

2.4.2 Demais Derivados do Leite .......................................................................... 33

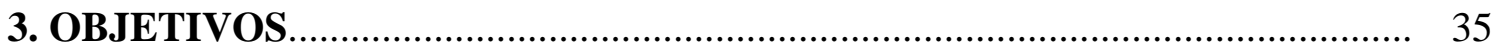

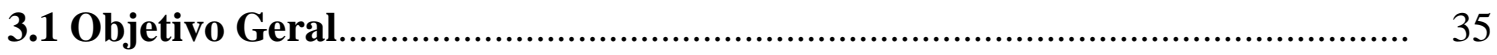

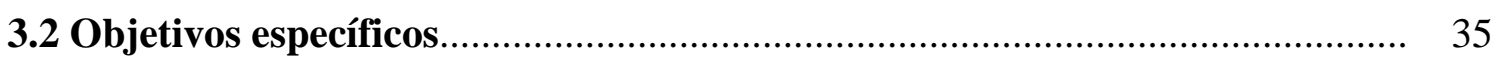

4. MATERIAL E MÉTODOS....................................................................... 36

4.1 Obtenção do Leite e Adequação dos Níveis de CCS.......................................... 36

4.2 Análises Laboratoriais e Elaboração dos Queijos............................................ 37

4.2.1 Análises do Leite Cru.................................................................................. 38

4.2.2 Tratamento Térmico do Leite e Análises do Leite Pasteurizado.................. 39

4.2.3 Coagulação, Tratamento da Massa, Enformagem e Embalagem................ 40

4.2.3.1 Queijo Minas Frescal................................................................................ 40

4.2.3.2 Queijo tipo Mussarela................................................................................... 43 
4.2.4 Análises Laboratoriais dos Queijos Minas Frescal e tipo Mussarela........... 46

4.2.4.1 Avaliação Físico-química......................................................................... 46

4.2.4.2 Avaliação da Proteólise .................................................................................. 46

4.2.4.3 Avaliação da Lipólise ...................................................................................... 47

4.2.4.4 Avaliação Microbiológica........................................................................... 48

4.2.4.5 Avaliação Sensorial...................................................................................... 49

4.2.4.6 Avaliação do Rendimento........................................................................ 52

4.2.4.7 Avaliação da Funcionalidade .................................................................... 52

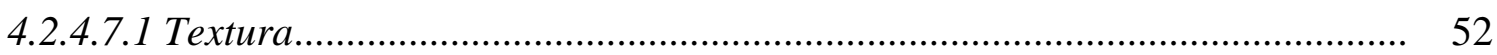

4.2.4.7.2 Capacidade de Derretimento - Queijo tipo Mussarela................................ 53

4.2.4.7.3 Determinação de Óleo Livre - Queijo tipo Mussarela................................ 54

4.3 Delineamento Experimental e Análise Estatística.......................................... 55

5. RESULTADOS E DISCUSSÃO ................................................................ 56

5.1 Queijo Minas Frescal............................................................................. 56

5.1.1 Leite In Natura ........................................................................................ 56

5.1.2 Leite Pasteurizado.................................................................................... 58

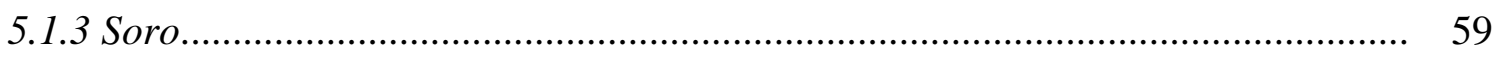

5.1.4 Queijo Minas Frescal............................................................................ 60

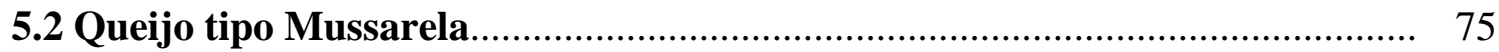

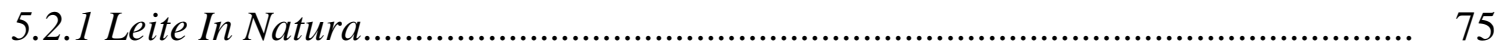

5.2.2 Leite Pasteurizado............................................................................................ 77

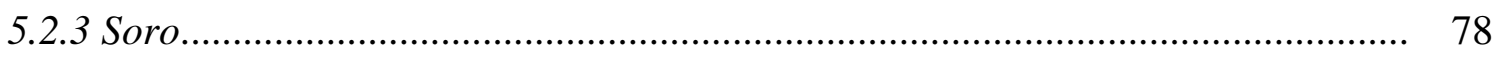

5.2.4 Queijo Tipo Mussarela......................................................................... 79

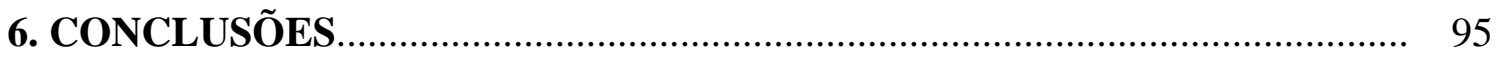

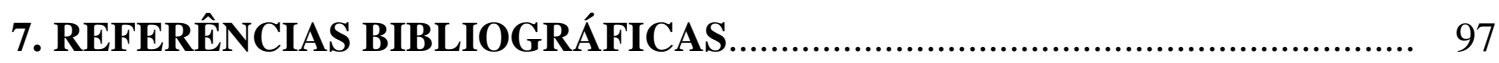




\section{INTRODUÇÃO}

A produção de leite do Brasil iniciou-se em 1532 e nestes quase cinco séculos de existência, a atividade desenvolveu-se sem grandes evoluções tecnológicas. A partir de 1950, a pecuária leiteira, juntamente com a industrialização, entrou na sua fase moderna. No final dos anos 1960, o leite tipo B alcançou expressão nacional, entretanto, a pecuária leiteira cresceu qualitativamente apenas a partir de 1980, com a entrada do produto longa vida no mercado, tornando-se hoje o leite mais consumido no país. Por volta de 1990, iniciou-se a era do livre mercado, marcada pelo fim do tabelamento do leite no Brasil, promovendo a desunião da classe, dispersão das bacias leiteiras e organização dos laticínios, que passaram a impor o preço do leite. Os reflexos negativos desta situação sobre a pecuária leiteira ainda ocorrem nos dias atuais, uma vez que os preços do leite são determinados pelo mercado (RUBEZ, 2006a).

Ao se falar em qualidade do leite, os avanços foram lentos e por etapas, pois o transporte do leite era realizado em latões não refrigerados. A introdução dos caminhões tanques isotérmicos e das geladeiras nas fazendas, no final dos anos 60, como exigia a legislação para o leite B, melhorou bastante a condições do transporte e a qualidade do leite.

O primeiro passo do Brasil num sistema mais moderno de transporte, igual ao que já existia nas nações mais evoluídas, ocorreu em 1976, iniciando-se assim a chamada coleta do leite a granel. Finalmente, o leite ganhava condições de manter-se numa cadeia de frio desde a fazenda até os pontos de vendas nas cidades. A coleta granelizada não se firmou imediatamente, pois nesta época a cultura do setor era a de punir pela baixa qualidade e não premiar pela alta. Falar em pagamento pela qualidade era quase que uma heresia. A implantação definitiva da coleta a granel só veio ocorrer na década de 90, quando uma palavra chave contaminou a economia brasileira e mundial: globalização. A partir deste momento a sociedade passa a ter uma postura mais crítica em relação aos produtos que compra, exigindo leite de melhor qualidade (RUBEZ, 2006a).

Entretanto, a qualidade insatisfatória do leite produzido no Brasil é um problema crônico, em que fatores de ordem social, cultural e econômica estão envolvidos. Ao se promover uma melhora na qualidade deve-se levar em conta que o controle inicia-se no 
processo de produção da fazenda através de aquisição e manutenção de animais saudáveis e um manejo higiênico e sanitário adequados. Nas etapas de industrialização, distribuição e comercialização, são inúmeros os cuidados que devem ser tomados, devendo se fazer um esforço integrado e conjunto para garantir a qualidade do produto final. Conseqüentemente, o investimento em qualidade beneficia diretamente a indústria, o consumidor e o produto, que recebe melhor pagamento pelo produto, através de premiação para cada uma das especificações de qualidade. Ao mesmo tempo, o produtor é beneficiado indiretamente através do diagnóstico e o combate à mastite, verificado pela quantidade de células somáticas, que levam a menor perda de produção por vaca.

A avaliação da qualidade do leite, mais usada no mundo está baseada nos padrões de contagem de células somáticas (CCS), porém utiliza-se também a contagem bacteriana total e os sólidos totais. A Nova Zelândia e Austrália, para se consolidarem no mercado mundial, já utilizam os sólidos totais como parâmetro para o pagamento do leite, enquanto que os EUA e Europa não seguem essa sistemática, pois estes países não dependem das exportações para serem melhores remunerados, pois têm os subsídios como compensação (RUBEZ, 2006b).

No Brasil os laticínios utilizam os litros de leite produzidos associados ao parâmetro CCS com política de pagamento do leite, e utilizam a penalização do produtor, através de descontos, em função da falta de sólidos. Estes fatos, porém não implicam na ocorrência de remuneração quando a qualidade está acima da mínima exigida.

O Ministério da Agricultura, Pecuária e Abastecimento fixaram através da Instrução Normativa $\mathrm{n}^{\circ}$ 51, de 18 de setembro de 2002, os requisitos mínimos de qualidade para o leite cru nas propriedades rurais, incluindo, pela primeira vez na legislação brasileira, limites máximos para CCS. Esta norma estabeleceu o limite máximo legal de 1.000 .000 céls./mL, em vigor a partir de julho de 2005 para as regiões Sul, Sudeste e Centro Oeste, e a partir de 2007 para as regiões Norte e Nordeste. Em 2008, o valor máximo deverá ser de 750.000 céls./mL, e em 2011, de 400.000 céls./mL (BRASIL, 2002).

O impacto econômico resultante da melhoria da qualidade ocorreu em todos os setores da cadeia agro-industrial do leite. O Brasil conseguiu aumentar em 2004, comparado ao ano de 2003, em 57,65\% o volume de leite vendido ao exterior, garantindo importante posição de exportador de leite e derivados. A produção de leite foi de 23.521.148 toneladas e a de queijos 13.373.000 toneladas, sendo que, destas, 5.000 toneladas foram exportadas (ANUALPEC, 2005).

Ao se trabalhar com leite de melhor qualidade tem-se a vantagem de possui maior concentração de sólidos totais (ST), de proteína e menor concentração de bactérias totais. Tal 
evidência promove rendimento industrial superior e, também o maior tempo de prateleira dos produtos derivados. A industrialização do leite com altas contagens de células conduz à redução no rendimento dos queijos, aumento do conteúdo de água e baixa taxa de enrijecimento do coágulo, alterações negativas nas propriedades organolépticas, defeitos de textura e elevada perda de sólidos no soro. Deve-se ressaltar, porém, que estes dados são originários de trabalhos científicos realizados em outros países, utilizando queijos pouco consumidos no Brasil (KLEI, et al., 1998; MARINO et al., 2005; MITCHELL, et al., 1986a).

Estes fatos justificam a importância do presente trabalho, cuja finalidade foi de avaliar o impacto do nível de células somáticas do leite utilizado como matéria-prima, sobre a qualidade dos principais queijos produzidos e consumidos em nosso país, Minas Frescal e tipo Mussarela. 


\section{REVISÃO DA LITERATURA}

\subsection{Considerações Gerais sobre Mastite e Contagem de Células Somáticas no Leite}

O leite contido na glândula mamária de animais saudáveis é considerado totalmente estéril, entretanto vários pontos são considerados críticos no que diz respeito à obtenção do leite. Imediatamente após a ordenha, o leite contém poucos microorganismos, porém, após um certo tempo, a carga microbiana do leite pode aumentar devido à contaminação por microrganismos provenientes do ambiente e do homem.

Os microrganismos infecciosos, por sua vez, são agentes causadores de mastite, definida pela International Dairy Federation (IDF, 1987) como uma inflamação da glândula mamária, a qual freqüentemente tem origem bacteriana (COSTA et al., 1995; LANGONI et al., 1998). Para Tronco (2003), esta é uma doença preocupante do rebanho leiteiro, capaz de proporcionar grandes prejuízos, não somente pela queda da produção láctea devido à perda da capacidade secretora da glândula mamária, mas também pelas alterações das características microbiológicas e físico-químicas do leite. Além disso, o risco de veiculação de microrganismos patogênicos e/ou suas toxinas através do leite atestam a importância das mastites e suas implicações em Saúde Pública, como salmoneloses, colibaciloses, listerioses, campilobacterioses, micobacterioses e iersinioses e intoxicações alimentares causadas por toxinas produzidas por Staphylococcus (FORSYTHE, 2002).

A mastite pode ser ocasionada por diversos microorganismos, cujo grupo mais abundante é o das bactérias (TRONCO, 2003). Mais de 80 diferentes espécies já foram identificadas como agentes causadores de mastite bovina (PHILPOT; PANKEY, 1975), sendo que as espécies mais freqüentemente isoladas são Staphylococcus aureus, Streptococcus agalactiae, Streptococcus dysgalactiae, Streptococcus uberis, Escherichia coli (HARMON, 1994), Corynebacterium sp., Prototheca sp., leveduras e fungos (TRONCO, 2003).

A resposta inflamatória da glândula mamária à colonização e multiplicação bacteriana apresenta como conseqüência direta o aumento no número de leucócitos de origem do sangue (células de defesas) que migram para dentro do lúmen alveolar (GODKIN, 2000). Estes leucócitos de origem do sangue, somados às células de descamação do epitélio glandular secretor, são denominados coletivamente de células somáticas do leite (NATZKE, 1981).

A contagem de células somáticas (CCS) é um teste rápido e facilmente obtido para determinação da qualidade do leite. Na glândula mamária de animais considerados sadios, a 
CCS é geralmente menor que 300.000 céls./mL de leite. Esta contagem aumenta rapidamente com a presença de bactérias dentro da glândula mamária, podendo chegar a 1.000.000 céls./mL em poucas horas (PAAPE; WEGIN; GUIDRY, 1981), indicando presença de bactérias na glândula, promovendo a inflamação da mesma.

De acordo com Schällibaum (2001), há quatro formas que a alta CS pode afetar a qualidade do leite processado, sendo: alteração na composição do leite; alteração nas propriedades tecnológicas; impacto na qualidade dos produtos derivados do leite e impacto econômico no processamento do leite. Sendo assim, a mastite é considerada a principal doença que afeta os rebanhos leiteiros no mundo, e aquela que proporciona as maiores perdas econômicas na produção de leite.

Calcula-se que, aproximadamente 17 a 20\% da população mundial de vacas leiteiras apresenta mastite em um dado momento. As estimativas de perdas por esse processo situamse entre 10 a 15\% da produção. Nos EUA, os prejuízos atingem dois bilhões de dólares anuais, devido à redução na produção dos quartos com mastite subclínica, que chegam a 70\% (ARENALES, 2005). De acordo com o Conselho Nacional de Mastite dos EUA (NATIONAL MASTITIS COUNCIL, 1996), em rebanhos para os quais não são adotadas medidas de controle, cerca de 50\% das vacas encontram-se infectadas, em média, em dois quartos cada.

No Brasil, há estimativas que apontam uma variação de 20\% (LANGENEGGER et al., 1970), 38\% (FONSECA, 1992) e até 71-72\% na prevalência da doença foram apontadas em rebanhos dos estados de Minas Gerais e São Paulo, resultando num prejuízo médio de U\$332,20 por vaca/ano (COSTA et al., 1999; ARENALES, 2005). Sendo assim, deduz-se que possa ocorrer perda de produção entre 12 e 15\%, o que significa um total de 2,8 bilhões de litros/ano em relação à produção anual de 21 bilhões de litros (FONSECA; SANTOS, 2000).

\subsection{Efeitos da Mastite sobre a Composição do Leite}

O leite é composto basicamente de substâncias sintetizadas na própria glândula mamária, além de substâncias transferidas diretamente do plasma sangüíneo para o interior dos alvéolos (TRONCO, 2003). Além de suas enzimas naturais (lipases, peroxidases, fosfatase, catalase entre outras), o leite possui também enzimas provenientes de microorganismos.

A mastite determina mudanças nas concentrações tanto dos principais componentes do leite (proteína, gordura e lactose), quanto de outros componentes (minerais). Os principais 
mecanismos pelos quais ocorre alteração nos níveis dos componentes do leite são as lesões às células epiteliais produtoras de leite, que pode resultar em alteração da concentração de lactose, proteína e gordura; e o aumento da permeabilidade das células epiteliais, que determina o aumento da passagem de substâncias do sangue para o leite, tais como sódio, cloro, imunoglobulinas e outras proteínas séricas (SCHULTZ, 1977; STEFFERT, 1993). Evidentemente, as alterações na composição do leite relacionadas à mastite irão depender da severidade da infecção e do estágio da doença, entretanto há uma relação direta entre CCS e concentração dos constituintes do leite (SCHÄLLIBAUM, 2001).

O leite normal apresenta naturalmente cerca de 60 diferentes enzimas, que podem estar associadas às micelas de caseína, à fase sérica do leite, à membrana dos glóbulos de gordura ou às partículas microssomais (GRUFFERTY; FOX, 1988; ANDREWS et al., 1991). Estas enzimas podem se originar das células epiteliais, do sangue ou dos leucócitos (ANDREWS et al., 1991). As concentrações de muitas enzimas ou mesmo a sua atividade enzimática no leite encontram-se aumentadas durante a mastite (KITCHEN, 1981), como é o caso das enzimas originárias do sangue e das células somáticas (FOX; MORRISSEY, 1981; ANDREWS et al., 1991).

As enzimas de maior importância para a indústria láctea são aquelas com atividades proteolíticas e lipolíticas, uma vez que o aumento da proteólise e lipólise no leite e derivados apresenta impacto negativo sobre a sua qualidade. O aumento da proteólise no leite reduz o rendimento na produção de queijos, e adicionalmente, a lipólise aumentada, a qual determina níveis elevados de ácidos graxos livres no leite, causa o desenvolvimento de sabor rançoso no leite e nos derivados.

Contudo, os resultados experimentais são conflitantes no tocante aos efeitos de elevadas CCS no leite sobre a concentração de proteína total do leite medida pela concentração total de nitrogênio. Diversos autores relataram que o leite de vacas com alta CCS apresentou maiores níveis de proteína total, quando comparado ao de vacas sadias (WEAVER; KROGER, 1977; MILLER et al., 1983; CASADO-CIMIANO; GARCIAALVARES, 1988; AULDIST et al., 1995 e KLEI et al., 1998). De forma contrária, Haenlein; Schultz e Zikakis (1973), Mitchell; Fedrick; Rogers (1986a) e Verdi et al. (1987) não identificaram diferenças nos teores de proteína total entre vacas com altas CCS e vacas sadias, enquanto Rogers et al. (1989) e Lee et al. (1991) relataram redução no teor de proteína total no leite de vacas com elevadas CCS.

Durante a mastite, a síntese de caseína encontra-se diminuída. Verdi et al. (1987), comparando a porcentagem de caseína no leite de diferentes fazendas, relataram que a 
concentração de caseína para o leite com alta CCS (673.000 céls./mL) foi menor (2,29-2,55\%) quando comparada com a do leite com baixa CCS (176.000 céls./mL), (2,36-2,61\%), ainda que esta diferença não tenha sido estatisticamente significativa. De forma inversa, Klei et al. (1998) descreveram que o leite com alta CCS (872.000 céls./mL) apresentou maior porcentagem de caseína (2,582\%) que o leite produzido pelas mesmas vacas antes da infecção (2,466\%), as quais apresentaram CCS média de 83.000 céls./mL.

Ainda que existam controvérsias sobre o efeito da CCS sobre a concentração da caseína, pode-se afirmar que à medida que aumenta a CCS, a relação entre caseína:proteína total é diminuída (VERDI et al., 1987; ROGERS et al., 1989; BARBANO; RASMUSSEN; LYNCH, 1991; KLEI et al., 1998). A redução na síntese de caseína no leite com alta CCS pode, em parte, ser explicada pela redução da capacidade de síntese e secreção de caseína devido ao dano causado ao epitélio secretor por toxinas bacterianas (OLIVER; CALVINHO, 1995).

Auldist e Hublle (1998) concluíram que ocorre aumento na concentração de proteínas de origem do sangue durante a inflamação, com concomitante redução na concentração de caseína do leite, resultando assim em alterações mínimas na concentração de proteína total no leite. O aumento na concentração de proteínas do sangue leva ao aumento na proporção de nitrogênio não-caseinoso (NNC). Dentre as proteínas séricas presentes no leite com alta CCS, Poutrel, Caffin e Rainard (1983) relataram aumentos na concentração de albumina sérica, e Caffin, Poutrel e Rainard (1985) descreveram aumento na concentração de imunoglobulinas nos quartos de úberes afetados. Estes aumentos na concentração de proteínas séricas no leite, durante a mastite, ocorrem possivelmente pela perda da integridade do epitélio mamário devido à ação de toxinas bacterianas (PAAPE; CAPUCO; GUIDRY, 1995). Para as proteínas séricas sintetizadas no epitélio secretor, $\alpha$-lactalbumina e $\beta$-lactoglobulina, a mastite determina redução nas suas concentrações (HAENLEIN; SCHULTZ; ZIKAKIS, 1973; ROGERS et al., 1989).

As alterações nas frações de proteínas do leite causadas pela mastite apresentam importantes implicações sobre o potencial do leite como matéria-prima para a fabricação de derivados, em especial de queijo. Desta forma, sistemas de pagamento baseados em porcentagem de proteína total, sem levar em conta a CCS, apresentam limitações, uma vez que o rendimento industrial do leite está associado principalmente à fração de caseína (AULDIST; HUBLLE, 1998; MA et al., 2000).

Os efeitos da mastite sobre as características da gordura do leite são estudados de maneira menos intensa, porém, até o momento, verificou-se que a extensão das alterações na 
concentração e composição da gordura do leite depende da severidade da mastite. No entanto, de forma geral, a concentração de gordura é reduzida no leite com alta CCS, em virtude da menor síntese de gordura pelas células epiteliais da glândula mamária (RANDOLPH; ERWIN, 1974; SCHULTZ, 1977). De forma similar aos efeitos da CCS sobre a proteína total do leite, os efeitos da mastite sobre a gordura podem ser de redução, aumento ou até mesmo de não alteração da gordura total, dependendo do volume de leite produzido (MUNRO; GRIEVE; KITCHEN, 1984). No leite normal, a gordura está presente na forma de emulsão de glóbulos graxos no soro do leite. Esta contribui para uma melhor palatabilidade do produto, além de ser responsável pelo grande número de ácidos graxos essenciais e valor calórico do leite (PRATA, 1998; TRONCO, 2003).

À medida que decorre o tempo de armazenamento, o leite e seus derivados desenvolvem odor e sabor conhecidos popularmente como ranço. Para Prata (1998), este termo denota a acumulação de ácidos graxos livres (AGL), obtidos da gordura do leite pela ação catalítica de lipases normalmente presentes no leite. A concentração AGL no leite fresco está aumentada durante a mastite. De acordo com Murphy et al. (1989), a concentração inicial de AGL no leite, imediatamente após a ordenha, foi cerca de 50\% maior para o leite com alta CCS (550.000 céls./mL) do que para o leite com baixa CCS (83.000 céls./mL).

De maneira semelhante, a quantidade e composição da membrana das gotículas de gordura do leite (MGGL) estão alteradas no leite com mastite (ERWIN; RANDOLPH, 1975; ANDERSON, 1977). De acordo com Erwin e Randolph (1975), no leite com alta CCS ocorre redução de 11,5\% na concentração de proteína, e de 8\% na concentração de fosfolipídios na MGGL. Anderson e Andrews (1977) relataram que a MGGL apresentou menores concentrações de fosfolipídios e de proteínas no leite com alta CCS quando comparado com o leite normal.

De acordo com vários autores (RANDOLPH; ERWIN, 1974; KITCHEN, 1981; STEFFERT, 1993), os triglicerídeos, transferidos do sangue para o leite com alta CCS são mais susceptíveis à lipólise que aqueles encontrados no leite normal. Esta maior susceptibilidade está relacionada com as alterações da MGGL, que proporcionariam uma proteção incompleta aos triglicerídeos presentes na gotícula de gordura e favoreceriam a associação da lipase lipoprotéica aos glóbulos de gordura (SUNDHEIM; BENGTSSONOLIVECRONA, 1987). Estas alterações na MGGL teriam com resultado final o aumento da lipólise da gordura do leite, assim como maior susceptibilidade à rancidez oxidativa (AGARWAL; NARAYANAN, 1979). 


\subsection{Efeitos da Mastite sobre a Microbiologia do Leite}

O leite obtido de vacas sãs pode sofrer contaminação com bactérias, devido principalmente à falta de higiene durante a ordenha, dos utensílios utilizados e dos animais. Entretanto deve-se considerar ainda a ausência de higiene na limpeza da glândula mamária, na limpeza das mãos e roupas do ordenhador e seus maus hábitos higiênicos, bem como na má qualidade da água empregada nestes processos.

As alterações provocadas no leite, em função do desenvolvimento bacteriano, dependem da quantidade e da composição da flora presente, em geral, estas alterações são resultantes pelas ações glicolíticas, proteolíticas e lipolíticas (TRONCO, 2003; PRATA, 1998).

Anteriormente à introdução da refrigeração nas propriedades leiteiras, as bactérias mesófilas, fermentadoras da lactose, eram os principais microorganismos deteriorantes do leite, promovendo rápida acidificação quando não refrigerado (ARCURI, 2003). Com o advento da refrigeração na propriedade e o maior tempo de armazenamento até a coleta, ocorreu a seleção da microbiota deteriorante, passando a estar presente em maior quantidade as bactérias psicrotróficas, capazes de crescerem a temperaturas de $7^{\circ} \mathrm{C}$ ou menos.

As bactérias psicrotróficas constituem o grupo que mais afeta a qualidade do leite e seus derivados atualmente. As espécies mais estudadas são Pseudomonas que produzem proteases e lipases. As primeiras apresentam maior atividade a 30-45 ${ }^{\circ} \mathrm{C}$, sendo significativamente ativas a $4{ }^{\circ} \mathrm{C}$, e possuem capacidade de coagular o leite, pois hidrolisam preferencialmente a $\kappa$-caseína, seguindo-se a $\beta$-caseína e $\alpha$-caseína. Já as lipases apresentam atividade ótima entre $22-70{ }^{\circ} \mathrm{C}$, permanecendo ativas em temperatura de refrigeração, apresentando a estabilidade térmica como característica notável, resistindo a temperatura de pasteurização (High Temperature Short Time) e até mesmo de ultrapasteurização (ARCURI, 2003).

De acordo com Prata (1998) a lipólise, oriunda da ação das lipases nativas possui pouca importância no que se refere ao leite cru antes da pasteurização, quando as condições higiênicas de produção e armazenamento são satisfatórias (MUIR, 1996). Entretanto, como as lipases sobrevivem à pasteurização, a sua atividade passa a ser muito importante, principalmente quando a lipólise é provocada por psicrotróficos (DOWNEY, 1980), pois provoca um aumento razoável de ácidos graxos $\mathrm{C}_{4}$ a $\mathrm{C}_{8}$ promovendo sabor e odor de ranço. 
Os ácidos graxos, de peso molecular maior, produzem sabor de sabão, enquanto os insaturados podem ser oxidados produzindo sabor metálico (ARCURI, 2003).

A proteólise, causada por enterobactérias, bactérias gram negativas e cocos gram positivos, também é indesejável, pois, leva há alterações de odor e sabor (sujo e amargo), de viscosidade e coagulação doce. Quando a proteólise é determinada por coliformes, esta dá origem a coágulo frágil e esponjoso (PRATA, 1998). O sabor amargo é resultante da liberação de peptídeos amargos (MA et al., 2000). A continuação da proteólise resulta em sabores e odores pútridos associados a produtos de degradação de baixo peso molecular, tais como amônia, aminas e sulfetos (ARCURI, 2003).

As bactérias ainda promovem processos glicolíticos ou sacarolíticos, que se caracterizam pelo desdobramento da lactose e produção de ácido lático, acidificando o meio e promovendo a coagulação ácida.

Para que as enzimas causem alterações no leite e derivados faz-se necessário que a população de psicrotróficas no leite atinja 1.000.000 a 10.000.000 UFC/mL (ARCURI, 2003; DOWNEY, 1980).

\subsection{Efeitos da Mastite sobre a Qualidade de Produtos Lácteos}

A qualidade dos produtos derivados de leite disponibilizados no mercado apresenta uma estreita relação com as características da matéria-prima entregue nas indústrias de processamento. Portanto, a qualidade do leite encaminhado às indústrias é essencial para o processamento dos produtos, sendo esta qualidade determinada pelas condições de saúde dos animais ordenhados, e pela manutenção das características próprias do leite durante o armazenamento e o transporte.

\subsubsection{Queijos}

A fabricação de qualquer tipo de queijo exige certos cuidados, cada um com sua particularidade, porém, o segredo do êxito reside exatamente na higiene (BEHMER, 1956). A elaboração de queijos constitui uma das mais importantes atividades das indústrias de laticínios, sobretudo no Brasil, onde os tipos de maior consumo compreendem Minas Frescal e o mussarela (BEHMER, 1980).

Entende-se por Queijo Minas Frescal, o queijo fresco obtido por coagulação enzimática do leite com coalho e/ou outras enzimas coagulantes apropriadas, complementada 
ou não com ação de bactérias lácticas específicas. É considerado um queijo semi-gordo (25 a 44\% de gordura na matéria seca), de muito alta umidade (não inferior a 55\%) a ser consumido fresco (BRASIL, 1996; BRASIL, 1997a). Já o queijo Mussarela é definido como o queijo que se obtém por filagem de uma massa acidificada, (produto intermediário obtido por coagulação de leite por meio de coalho e/ou outras enzimas coagulantes apropriadas), complementada ou não pela ação de bactérias lácticas específicas, sendo um queijo de média (36 a 45,9\%), alta (46 a 54,9\%) ou muito alta (não inferior a 55\%) umidade e extragordo (mínimo de 60\%), gordo (45,0 a 59,9\%) a semigordo (25 a 44,9\% de gordura na matéria seca) (BRASIL, 1996; BRASIL, 1997b). Em ambos os queijos, o pH varia de 5,0 a 5,3 ao utilizar fermento e de 6,1 a 6,3 ao utilizar ácido lático (FURTADO; LOURENÇO NETO, 1994).

Estes queijos representam cerca de $40 \%$ do montante comercializado no país, cuja produção concentra-se, principalmente, em indústrias de pequeno e médio porte. Isto se deve, em parte, ao maior rendimento obtido na elaboração, ao seu processamento simples e a sua rápida comercialização, o que possibilita um retorno quase imediato do investimento e, conseqüentemente, custos menores aos consumidores (PINTO; GERMANO; GERMANO, 1996).

As principais alterações ocorridas no queijo produzido com leite apresentando CCS elevadas são: a redução no rendimento industrial (GRANDISON, 1986); aumento do conteúdo de água no coágulo (MITCHELL; FEDRIK; ROGERS, 1986b); alterações negativas nas propriedades organolépticas (AULDIST et al., 1996b; MUNRO; GRIEVE; KITCHEN, 1984); aumento do tempo para formação do coágulo (KLEI et al., 1998; ROGERS; MITCHELL, 1994); baixa taxa de enrijecimento do coágulo e defeitos de textura (KLEI et al., 1998; POLITIS; NG KWAI HANG, 1988a,b,c) e elevada perda de sólidos no soro do queijo (BARBANO; RASMUSSEN; LYNCH, 1991).

Segundo Politis e Ng-Kwai-Hang (1988a), níveis de CCS acima de 100.000 céls./mL podem ter efeito negativo sobre a produção de queijos de alta qualidade. Conclusão semelhante já destacada por Grandinson (1986), verificada pela perda de rendimento e qualidade do queijo associada com a alta retenção de umidade no coágulo e uma excessiva perda de gordura no soro. Em estudo avaliando o efeito da CCS sobre a composição do leite e do queijo, realizada por Politis e Ng-Kwai-Hang (1988a), foi verificado que níveis de CCS afetam significativamente os conteúdos de gordura, proteína, sólidos totais e a proporção de umidade das substâncias não gordurosas, onde o leite contendo 600.000 céls./mL apresentou um queijo com $0,5 \%$ menos de gordura, $0,4 \%$ menos de proteína, $0,9 \%$ menos sólidos totais e 0,9\% mais de umidade que o queijo produzido com 100.000 céls./mL. Barbano, Rasmussen e 
Lynch (1991) também observaram um decréscimo na caseína quando leite com CCS maior que 100.000 céls./mL, verificando perda da caseína pelo soro durante a fabricação de queijo tipo Cheddar.

O rendimento é afetado por vários fatores, sendo eles diretos e indiretos. A composição do leite através do teor de gordura e proteínas, a composição do queijo influenciada principalmente por seu teor de umidade e suas perdas obtidas no corte da coalhada são considerados os fatores diretos. Já os fatores indiretos que afetam o rendimento são estocagem do leite a frio que provoca mudanças físico-químicas no leite, a contagem de bactérias psicrotróficas, pois estas produzem enzimas de alta termo-resistência, a atividade da plasmina que promove atividade proteolítica na caseína, o tipo de coalho utilizado, a pasteurização do leite e a contagem de células somáticas, que através de suas enzimas proteolíticas degradam a caseína e através de componentes antimicrobianos inibem a atividade das culturas láticas (O RENDIMENTO..., 2005).

De acordo com Auldist e Hublle (1998), estas alterações no rendimento e na qualidade do queijo de alta CCS estão diretamente relacionadas com as alterações na composição da proteína (redução da síntese de caseína), no balanço de minerais, e com a atividade enzimática oriundas das células somáticas.

Vários estudos mostram que a variação na porcentagem de umidade que, por sua vez, regula o rendimento do queijo pode estar associada com a variação da CCS, ou seja, altas CCS estão associadas com alta umidade do queijo. Politis e Ng-Kwai-Hang (1988b) comprovaram este fato, verificando que o incremento de 100.000 céls./mL para 900.000 céls./mL foi associado com decréscimo de eficiência no rendimento, também constatado por Schällibaum (2001). Klei et al. (1998) verificaram que o incremento na CCS de 83.000 céls./mL para 872.500 céls./mL influenciou a composição do leite, do queijo cottage e seu rendimento, onde a eficiência no rendimento foi inferior para o coalho do queijo cottage fabricado de leite com alta CCS. Em estudo realizado com queijo Minas Frescal, Matioli et al. (2000) verificaram que o queijo obtido do leite com altas CCS apresentou menor acidez, acarretando alteração no sabor, maior perda de gordura e proteína solúvel pelo soro, e menor rendimento da fabricação (9,81\%), quando comparado com leite de baixa CCS. Resultados semelhantes a estes foram obtidos por Barbano e Sherbon (1984), ao analisar queijo Cheddar.

Como citado anteriormente, a qualidade do leite faz-se necessária, pois a presença de microorganismos provoca alterações no leite e conseqüentemente nos queijos. Das bactérias presentes, as psicrotróficas são as mais preocupantes, pois estas possuem grupos de bactérias patogênicas, veiculadoras de toxinfecções alimentares. 
No queijo os principais efeitos da presença de bactérias psicrotróficas são as alterações no sabor devido à formação de ranço, de sabão ou o amargo, com conseqüente perda da qualidade do produto (SANTOS; CARVALHO; ABREU, 1999).

Quanto mais proteolisado (maturado) esteja o queijo, mais macia será sua consistência e seu aroma mais pronunciado (ADDA; GRIPON e VASSAL, 1982). No queijo Minas Frescal, segundo Wolfschoon-Pombo et al (1984) uma proteólise avançada, caracterizada por uma cor amarelada e consistência mole, é um atributo negativo de sua qualidade.

Outra característica importante na qualidade e conseqüentemente aceitação de um queijo é a sua textura. Sendo assim, textura da massa pode ser definida como sendo a forma em estão dispostas às partes que a compõem e que, independentemente do seu tamanho lhe conferem características reológicas particulares (TEXTURA...., 2002a). Esta tem importância vital tanto na comercialização como no consumo, pois a massa exerce função determinante na conservação, estabilidade, maturação, análise e diferenciação do tipo de queijo.

Vários são os constituintes que influenciam a textura do queijo. Em destaque considera-se a quantidade de gordura, de cálcio (Ca), de proteínas, mais especificamente a caseína, da matéria-prima e também o pH da massa. O teor de umidade tem efeito determinante, pois quanto mais elevado o teor de umidade da massa, mais macia será sua consistência (TEXTURA..., 2002b). Segundo Lucey, Johnson e Horne (2003) no queijo Mussarela, as mudanças na quantidade expressável de água são causadas por efeitos combinados de solubilização lenta de fosfato de cálcio coloidal e avanço na proteólise. Esta proteólise, por sua vez, gera novos grupos iônicos que influenciam, não somente, a expressabilidade de água do queijo, mas também os atributos sensoriais (CREAMER; OLSON, 1982; AULDIST; HUBBLE, 1998).

A pasteurização, o sal e a atividade de enzimas proteicas também influenciam a textura durante o armazenamento. Em estudo com queijo Cheddar, Rynne et al. (2004) verificaram que à medida que houve um incremento na temperatura de pasteurização $\left(72{ }^{\circ} \mathrm{C}\right.$ a $82^{\circ} \mathrm{C}$ ) a firmeza apresentou um decréscimo, o que coincidiu com o incremento na proteína do soro desnaturada. Já em relação ao sal, este atua indiretamente, pois ao ser absorvido reage com o cálcio presente, logo haverá menos cálcio ligado à proteína, conseqüentemente mais firme e curta será a massa. Segundo Thomas e Pearce (1981), a relação sal/umidade afeta sensivelmente a taxa de proteólise durante a maturação do queijo. De acordo com Monib (1962) apud Lucey, Johnson e Horne (2003), o impacto da difusão do sal nas propriedades do queijo é complexo e dependente de $\mathrm{pH}$, conteúdo de umidade, temperatura, de sua concentração e concentração de cálcio. 


\subsubsection{Demais Derivados Lácteos}

Em leites pasteurizados e esterilizados (tratados através do processo Ultra High temperature - UHT), o estudo da CCS é comum e muito importante, até porque com as modificações sócio-culturais, econômicas e da legislação brasileira, este tipo de leite tornouse presente na mesa dos consumidores, pela praticidade e durabilidade do produto.

Além das mudanças na composição, a qualidade tecnológica do leite também sofreu alterações devido à presença de altos níveis de células somáticas, ocasionando redução da estabilidade ao calor e redução da vida de prateleira de leites tratados com calor (SCHÄLLIBAUM, 2001). Esta redução é devido ao incremento da concentração de imunoglobulinas e soro-albumina provenientes do sangue, causando floculação sedimentação durante o processo de tratamento pelo calor.

Em pesquisa realizada por Auldist et al. (1996a), ao analisar leites com diferentes níveis de células somáticas verificaram diferenças nas características sensoriais, principalmente no leite UHT de alta CCS que apresentou maior geleificação.

De acordo com Brus e Jaartsveld (1971) a redução da estabilidade ao calor, em leite com alta CCS teve impacto negativo em algumas propriedades do leite em pó ou leite evaporado, revelando sabor semelhante a queimado e sabor rançoso na estocagem. Já em trabalho realizado por Rogers e Mitchell (1989) nenhum efeito conclusivo foi encontrado na qualidade de leite em pó obtido por pulverizador a seco, nem na aceitabilidade organoléptica do leite pasteurizado.

Needs, Anderson e Kirby (1988), analisaram creme chantily e verificaram que as CS afetam as propriedades do creme. Auldist e Huble (1998) citam que a capacidade espumante do leite utilizado para fabricação do café cappuccino também é afetada pelas células somáticas.

Pesquisas realizadas com manteiga indicam que há um incremento no tempo de coagulação, uma marcada deterioração nas propriedades organolépticas dos produtos processados, composição alterada, aumento no tempo de separação e preparação da manteiga feita de leite com altas CCS (AULDIST e HUBBLE, 1998). Assim, a manteiga obtida de leite com altas células somáticas deteriora mais rápido durante o período de estocagem.

Os efeitos da CCS em iogurtes também são freqüentemente estudados, pois o nível alto de células somáticas do leite utilizado na fabricação determina impacto negativo sobre o 
crescimento das culturas lácteas, afetando assim, o processo de fabricação e a qualidade do produto final.

Oliveira et al. (2002) verificaram que leite com $>800.000$ céls./mL demonstra um decréscimo na qualidade sensorial, apresentando uma relação negativa principalmente quanto a consistência e sabor do iogurte, avaliado durante 30 dias. Já Rogers e Mitchell (1994), relataram efeitos inconsistentes no que cerca as propriedades organolépticas do iogurte desnatado, porém verificaram que os dados de uma propriedade indicaram que a qualidade do iogurte é significativamente afetada quando leite de >250.000 céls./mL é utilizado. 


\section{OBJETIVOS}

\subsection{Objetivo Geral}

O objetivo geral foi avaliar o impacto do nível de células somáticas do leite utilizado como matéria prima, sobre a fabricação e qualidade dos queijos Minas Frescal e tipo Mussarela. Bem como gerar conhecimentos sobre o tema para produtores, indústrias processadoras e órgãos de fiscalização da área.

\subsection{Objetivos Específicos}

a) Determinar as características físico-químicas, microbiológicas, funcionais, de composição, rendimento e textura dos queijos Minas Frescal e tipo Mussarela;

b) Avaliar as possíveis diferenças entre os parâmetros estudados, nos queijos produzidos a partir de leite integral contendo três níveis de CCS (100.000-200.000 céls./mL, 400.000-500.000 céls./mL e >800.000 céls./mL);

c) Avaliar a interação entre os níveis de células somáticas e o tempo de armazenamento dos queijos mantidos a $4^{\circ} \mathrm{C}$ por 30 dias. 


\section{MATERIAL E MÉTODOS}

\subsection{Obtenção do Leite e Adequação dos Níveis de CCS}

Para a obtenção do leite, inicialmente, foram coletadas amostras individuais de leite, de vacas em lactação disponíveis no Campus Administrativo da USP e de propriedades particulares de Pirassununga. As amostras foram coletadas através de medidores, em frascos de $100 \mathrm{~mL}$ contendo conservante, feita em duas ordenhas, manhã e tarde, e enviadas para a análise da contagem de células somáticas (CCS) através de contador eletrônico de células somáticas $\left(\right.$ Bentley $^{\circledR}$ ), no Laboratório de Fisiologia da Lactação/Departamento de Produção Animal da Escola Superior de Agronomia Luiz de Queiroz (ESALQ/USP), em Piracicaba/SP. A partir desta análise, foi efetuada a seleção das vacas que possuíssem leite com 100.000200.000 céls./mL, 400.000-500.000 céls./mL e >800.000 céls./mL, até atingir 100 litros de leite para cada nível.

Para verificar as condições sanitárias do leite do rebanho a ser utilizado no experimento, foram colhidas amostras do tanque de mistura, durante três dias consecutivos, para análises microbiológicas, de acordo com os procedimentos descritos pela American Public Health Association (1992). Os leites colhidos apresentaram contagem de mesófilos

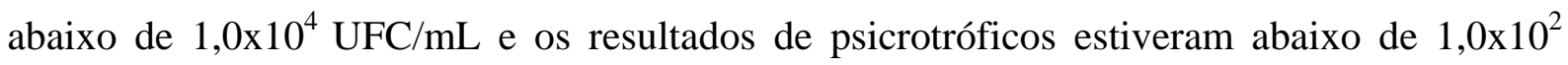
UFC/mL, limites permitidos de acordo com Brasil (2001).

Foram selecionadas vacas, em estágio de lactação intermediário e, que não foram submetidos ao tratamento com antibiótico nos sete dias anteriores. Estas vacas foram submetidas à ordenha, quatro dias após a coleta das amostras para obtenção de CCS, sendo cada grupo ordenhado separadamente. Para cada nível de células somáticas foram coletados 100 litros de leite, independente do número de vacas. Esta coleta foi realizada em sala apropriada, contendo todos os equipamentos necessários para a ordenha mecânica, sendo o leite de cada grupo recolhido em latões de polipropileno higienizados, de capacidade de 50 litros cada. Após a obtenção do leite, os latões foram imediatamente armazenados em câmara fria a $4{ }^{\circ} \mathrm{C}$, localizada no Laticínio do Campus, até o processamento dos queijos. 
Anterior a cada processamento foi coletada amostra em duplicata, e encaminhadas ao laboratório, para confirmação dos níveis de CS. Os níveis de células somáticas do leite cru utilizados para a fabricação dos lotes de Minas Frescal e tipo Mussarela estão descritos na Figura 1 (a e b), respectivamente.
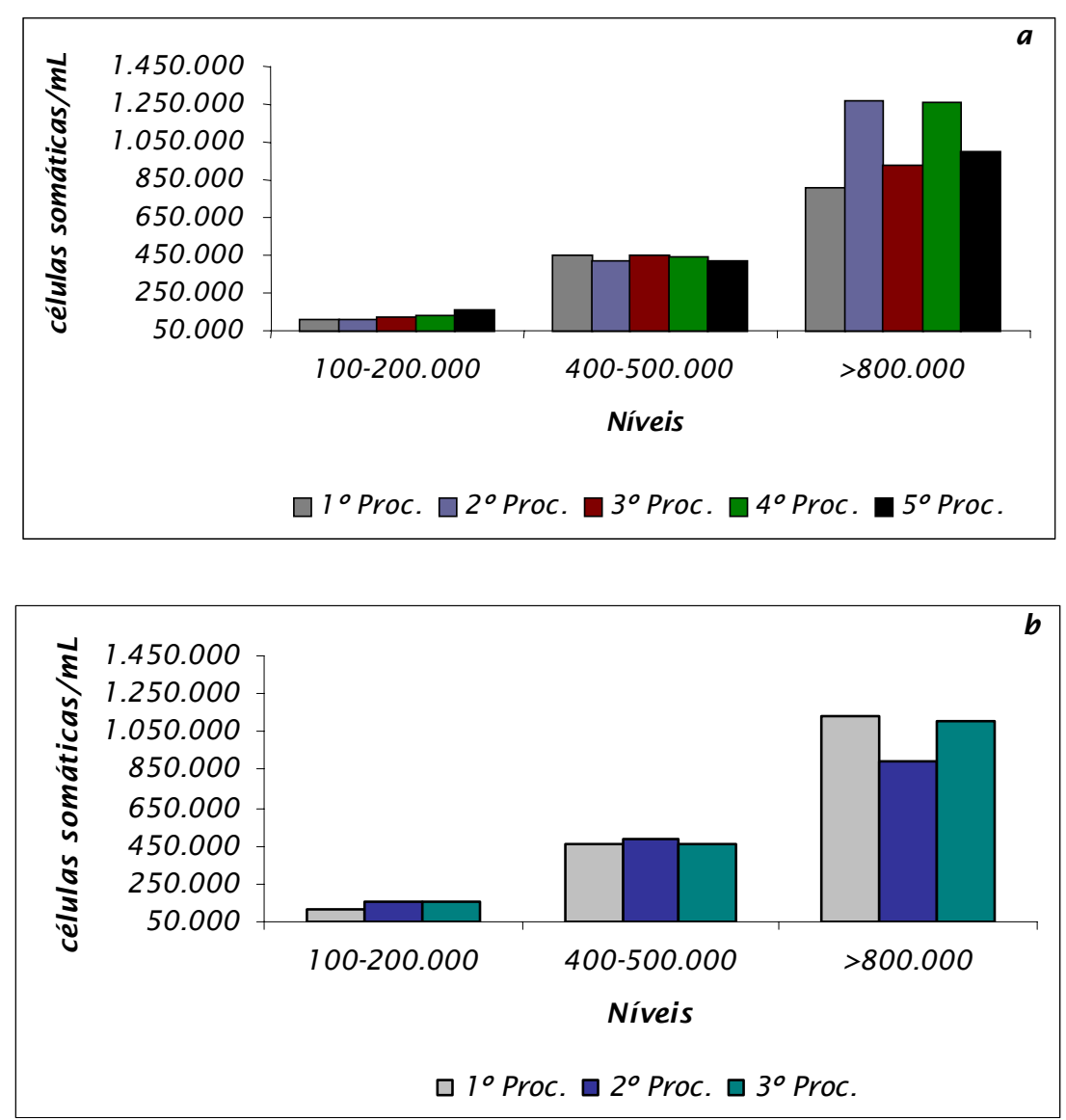

Figura 1. Contagem de células somáticas no leite utilizado para fabricação dos lotes dos queijos Minas Frescal (a) e tipo Mussarela (b).

\subsection{Análises Laboratoriais e Elaboração dos Queijos}

Os três tipos de leites, obtidos nas condições estabelecidas no item anterior, foram utilizados na fabricação dos queijos Minas Frescal e tipo Mussarela, realizada no Setor de Laticínios do Campus, no máximo, 24 horas após a ordenha. Cada tipo de queijo foi processado separadamente, no mesmo dia, obedecendo aos critérios de elaboração descritos por Oliveira (1986).

O resumo das análises realizadas no leite cru, pasteurizado soro e nos queijos é apresentado no Quadro 1. 
Quadro 1 - Resumo das análises laboratoriais executadas no experimento.

\begin{tabular}{|c|c|}
\hline Análises Físico-Químicas & Referências \\
\hline $\begin{array}{l}\text { Acidez titulável } \\
\text { Alizarol } \\
\text { Densidade a } 15^{\circ} \mathrm{C} \\
\text { Fosfatase e peroxidase } \\
\text { Índice crioscópico } \\
\text { pH }\end{array}$ & $\begin{array}{l}\text { Instituto Adolfo Lutz }(1985)^{1,2,3} \text {; Brasil } \\
(1981)^{4,5} \\
\text { Instituto Adolfo Lutz }(1985)^{1} \\
\text { Instituto Adolfo Lutz }(1985)^{1} \\
\text { Instituto Adolfo Lutz (1985) })^{1,2} \\
\text { Instituto Adolfo Lutz (1985) })^{1} \\
\text { Instituto Adolfo Lutz (1985) })^{1,2,3} \text {; Brasil } \\
(1981)^{4,5}\end{array}$ \\
\hline \multicolumn{2}{|l|}{ Análises Microbiológicas } \\
\hline $\begin{array}{l}\text { Coliformes } 30{ }^{\circ} \mathrm{C} \\
\text { Coliformes } 45^{\circ} \mathrm{C} \\
\text { Contagem de mesófilos } \\
\text { Contagem de psicrotróficos }\end{array}$ & APHA $(1992)^{1,2,4,5}$ \\
\hline \multicolumn{2}{|l|}{ Análises de Composição } \\
\hline $\begin{array}{l}\text { Ácidos Graxos Livres (Índice de Lipólise) } \\
\text { Cinzas } \\
\text { Gordura } \\
\text { Lactose } \\
\text { Matéria seca } \\
\text { Proteína (Índice de Proteólise) } \\
\text { Sólidos Totais } \\
\text { Sólidos Não Gordurosos }\end{array}$ & 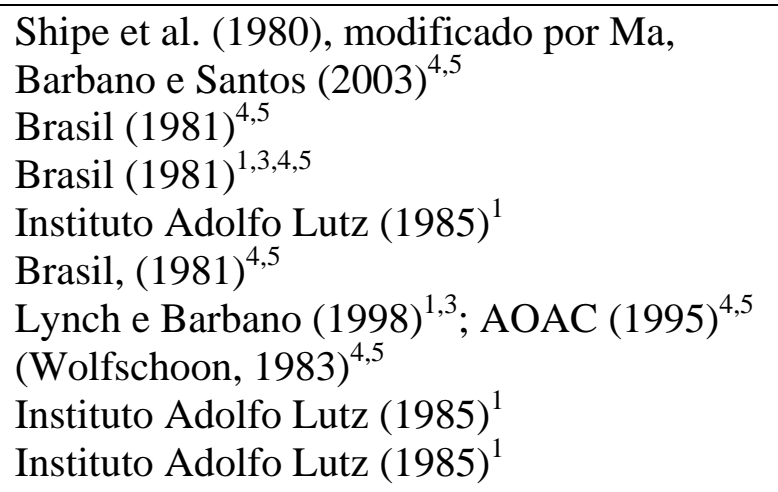 \\
\hline \multicolumn{2}{|l|}{ Análises de Funcionalidade } \\
\hline $\begin{array}{l}\text { Textura } \\
\text { Capacidade de derretimento } \\
\text { Determinação de óleo livre }\end{array}$ & $\begin{array}{l}\text { Chaves }(1997)^{4,5} \\
\text { Kosikowski }(1982)^{5} \\
\text { Kindstead e Fox }(1991)^{5}\end{array}$ \\
\hline Análise Sensorial & Amerine et al. $(1967)^{4,5}$ \\
\hline Análise de Rendimento & Klei et al.(1998) ${ }^{4,5}$;Yenes e Benedet $(2000)^{4,5}$ \\
\hline
\end{tabular}

\subsubsection{Análises do Leite Cru}

O conteúdo total de cada mistura (cerca de 100 L) foi entornado, após filtragem, em tanques de fabricação de queijo, de capacidade máxima de 100 L. Foram retiradas amostras de leite cru para, confirmação da CCS (Figura 2), determinação da acidez titulável, pH, 
densidade a $15{ }^{\circ} \mathrm{C}$, índice crioscópico, alizarol (INSTITUTO ADOLFO LUTZ , 1985), contagem de mesófilos, psicrotróficos e coliformes a $30^{\circ} \mathrm{C}$ e a $45^{\circ} \mathrm{C}$ (APHA, 1992) e análises de composição,como proteína (LYNCH; BARBANO, 1998), teores de gordura, sólidos totais (ST) e sólido não gorduroso (SNG) (INSTITUTO ADOLFO LUTZ , 1985).

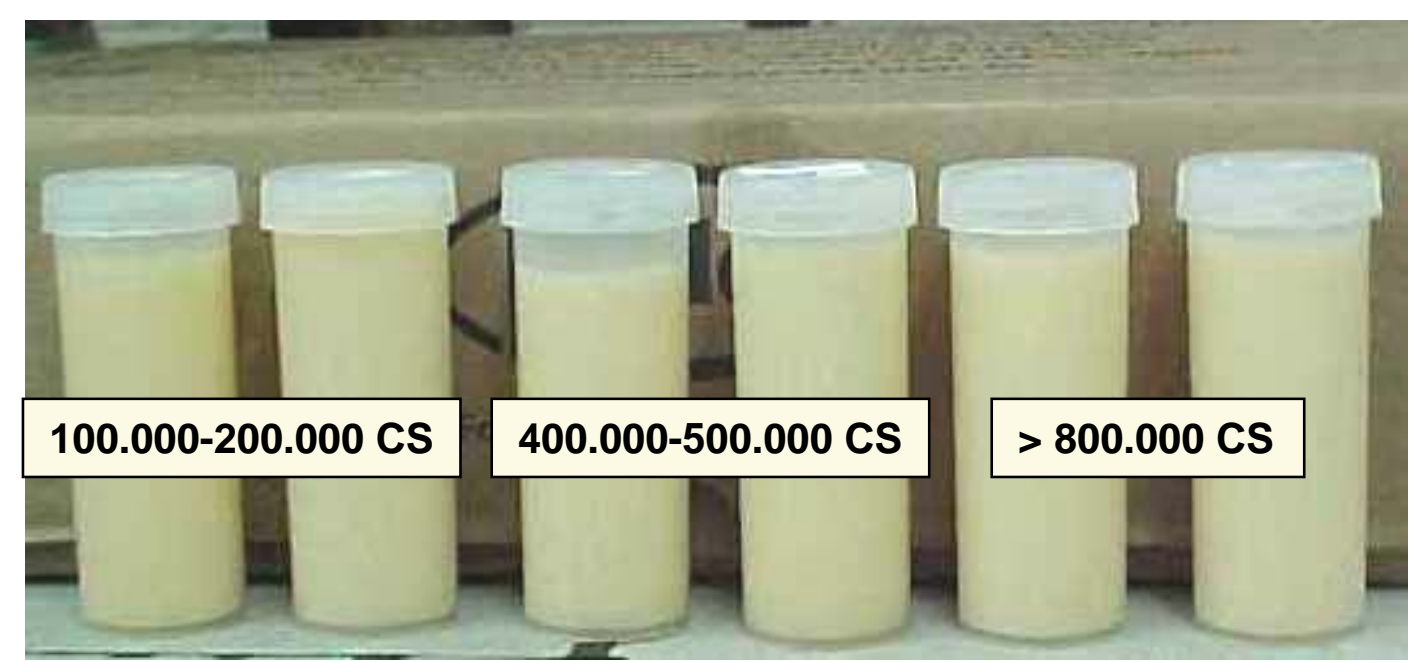

Figura 2. Amostras de leite para confirmação do nível de células somáticas.

\subsubsection{Tratamento Térmico do Leite e Análises do Leite Pasteurizado}

No tanque de fabricação, os leites sofreram tratamento térmico à temperatura de $65{ }^{\circ} \mathrm{C}$ por 30 minutos (Figura 3), seguido de resfriamento imediato, para cerca de $34{ }^{\circ} \mathrm{C}$. Neste momento, foi coletada amostra para determinação de acidez titulável, pH (INSTITUTO ADOLFO LUTZ, 1985), análise microbiológica (contagem de mesófilos, psicrotróficos e coliformes a $30{ }^{\circ} \mathrm{C}$ e $45{ }^{\circ} \mathrm{C}$ (APHA, 1992)) e armazenamento. A eficiência do tratamento térmico foi avaliada pela análise de fosfatase alcalina e peroxidase (INSTITUTO ADOLFO LUTZ, 1985). 


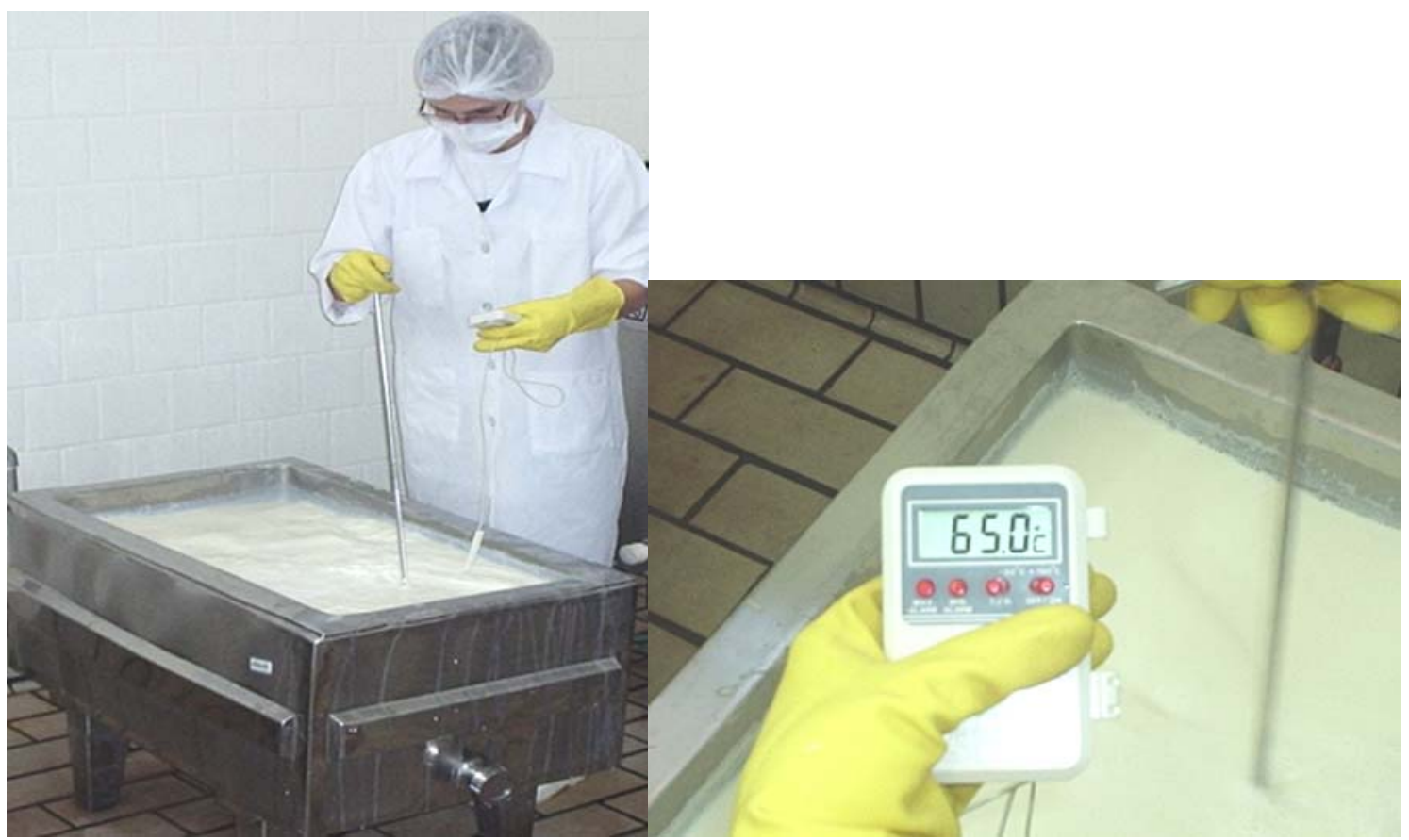

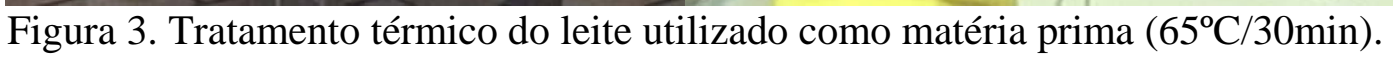

\subsubsection{Coagulação, Tratamento da Massa, Enformagem e Embalagem}

\subsubsection{Queijo Minas Frescal}

Para a fabricação do queijo Minas Frescal, após a pasteurização foi acrescentada a solução de cloreto de cálcio 250 ppm e coalho em pó bovino (Christian-Hansen ${ }^{\circledR}$ ), a base de quimosina e pepsina. A quantidade de coalho utilizada foi calculada a partir do cálculo da força do coalho, em quantidade suficiente para coagular o leite em 35 minutos.

Obtido o coágulo, após tempo pré-estabelcido, foi realizado o corte da coalhada, com auxílio de liras horizontal e vertical (Figura 4a e 4b), em fragmentos de $1 \mathrm{~cm}$ de aresta (Figura 4c), aproximadamente. Após cinco minutos do corte, iniciou-se a agitação contínua e lenta da massa, mantida por 25 minutos. Após cinco minutos de repouso da massa, realizou-se a amostragem do soro, para análises físico-químicas (acidez titulável e pH), e a dessoragem parcial, retirando 2/3 do volume de soro (Figura 4d). Este soro foi pesado para fins de cálculo da quantidade de sal a ser adicionada na massa (3,5\%). O sal foi diluído e acrescentado na massa, enquanto agitado por dois minutos.

A massa obtida foi transferida, higienicamente, para fôrmas plásticas de 250 gramas (Figura 4e), permanecendo por 15 minutos até sofrer a primeira viragem (Figura 4f). As duas demais foram realizadas em intervalo de 30 minutos. Em seguida, os queijos foram 
armazenados em câmara fria à temperatura de $4{ }^{\circ} \mathrm{C}$. Após 24 horas, os queijos foram retirados das formas, embalados a vácuo (Figura 4g) e conservados em B.O.D. (Tecnal TE-391) a $4{ }^{\circ} \mathrm{C}$ por 30 dias.
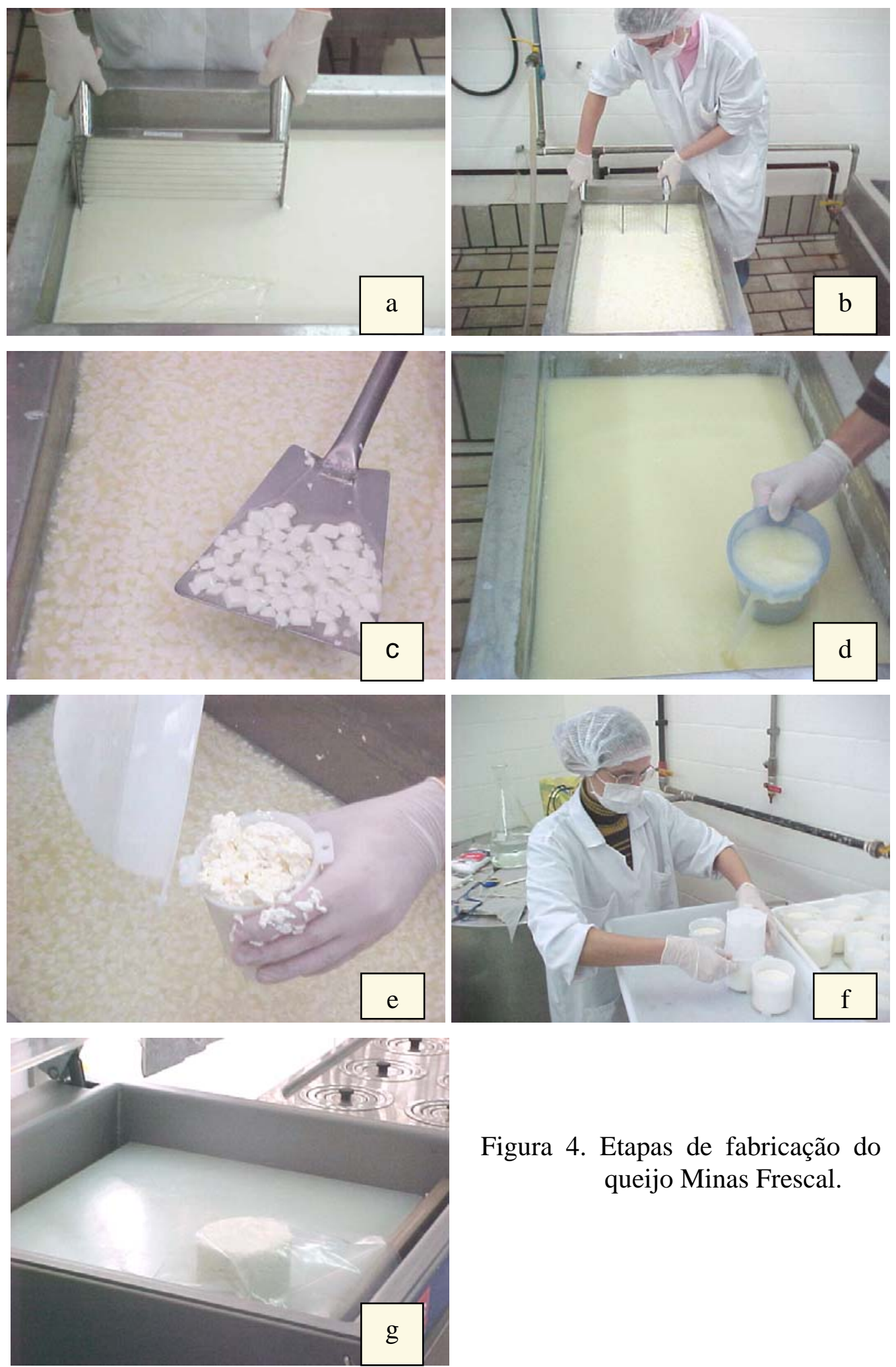

Figura 4. Etapas de fabricação do queijo Minas Frescal. 
O procedimento de elaboração (Quadro 2) foi repetido cinco vezes para cada tratamento, totalizando, aproximadamente, 195 quilos de queijo Minas Frescal.

Quadro 2. Fluxograma de fabricação do queijo Minas Frescal

\begin{tabular}{|c|c|}
\hline \multicolumn{2}{|c|}{ Queijo Minas Frescal } \\
\hline \multicolumn{2}{|c|}{100 litros leite cru resfriado } \\
\hline$\downarrow$ & $\hookrightarrow$ Coleta amostra de leite CRU \\
\hline \multicolumn{2}{|c|}{ Tratamento térmico $65^{\circ} \mathrm{C} / 30^{\prime}$} \\
\hline$\downarrow$ & $\hookrightarrow$ Coleta amostra de leite PASTEURIZADO \\
\hline \multicolumn{2}{|c|}{ Resfriamento a $34^{\circ} \mathrm{C}$} \\
\hline \multicolumn{2}{|c|}{$\downarrow$} \\
\hline \multicolumn{2}{|c|}{ Adição de $\mathrm{CaCl}_{2}$ 250ppm } \\
\hline \multicolumn{2}{|c|}{$\downarrow$} \\
\hline \multicolumn{2}{|c|}{ Agitação } \\
\hline \multicolumn{2}{|c|}{$\downarrow$} \\
\hline \multicolumn{2}{|c|}{ Adição Coalho - Obtido pela força do coalho (coagular em 35’) } \\
\hline \multicolumn{2}{|c|}{$\downarrow$} \\
\hline \multicolumn{2}{|c|}{ Agitação por 2’ } \\
\hline \multicolumn{2}{|c|}{$\downarrow$} \\
\hline \multicolumn{2}{|c|}{ Repouso por 35’ (Coagulação) } \\
\hline \multicolumn{2}{|c|}{$\downarrow$} \\
\hline \multicolumn{2}{|c|}{ Corte $\left(1^{\circ}\right.$ lira horizontal, em $2^{\circ}$ lira vertical - cubos de $1-1,5 \mathrm{~cm}$ aresta) } \\
\hline \multicolumn{2}{|c|}{$\downarrow$} \\
\hline \multicolumn{2}{|c|}{ Repouso da massa por 5’ } \\
\hline \multicolumn{2}{|c|}{$\downarrow$} \\
\hline \multicolumn{2}{|c|}{ Tratamento da massa (agitação contínua por 25’) $\rightarrow$ Agitação lenta no início } \\
\hline \multicolumn{2}{|c|}{$\downarrow \quad \sqcup \quad \sqcup$ Manter $34^{\circ} \mathrm{C}$} \\
\hline \multicolumn{2}{|c|}{ Dessoragem parcial $\quad \rightarrow$ Deixar coágulo levemente imerso } \\
\hline \\
\hline \multicolumn{2}{|c|}{$\downarrow \quad \sqcup$ Coleta amostra de soro } \\
\hline \multicolumn{2}{|c|}{ Adição de sal na massa } \\
\hline$\downarrow$ & $\llcorner 3,5 \%$ do peso da massa e agitação suave \\
\hline \multicolumn{2}{|c|}{ Agitação por 1’' } \\
\hline \multicolumn{2}{|c|}{$\downarrow$} \\
\hline \multicolumn{2}{|c|}{ Enformagem } \\
\hline$\downarrow$ & $\hookrightarrow$ Recuperar o soro e pesar \\
\hline Viragens & $\rightarrow$ 15’, 30' e 60' (temp. amb.) \\
\hline$\downarrow$ & $\hookrightarrow$ Recuperar o soro e pesar \\
\hline \multicolumn{2}{|c|}{ Resfriamento em câmara fria a $4-5^{\circ} \mathrm{C}$ (nas formas) por 24 horas } \\
\hline$\downarrow$ & $\hookrightarrow$ Recuperar o soro e pesar \\
\hline Desenformar, pesar e el & mbalar a vácuo \\
\hline
\end{tabular}




\subsubsection{Queijo tipo Mussarela}

Na fabricação do queijo tipo Mussarela, após resfriamento (34 $\left.{ }^{\circ} \mathrm{C}\right)$ do leite pasteurizado, foi adicionada solução cloreto de cálcio a 250 ppm e fermento termofílico (Christian-Hansen $^{\circledR}$ ) deixado em repouso por 60 minutos (Figura 5). Em seguida, adicionouse o coalho líquido bovino (Três coroas), a base de quimosina e pepsina. A quantidade de coalho utilizada foi calculada a partir do cálculo da força do coalho, em quantidade suficiente para coagular o leite em 35 minutos.

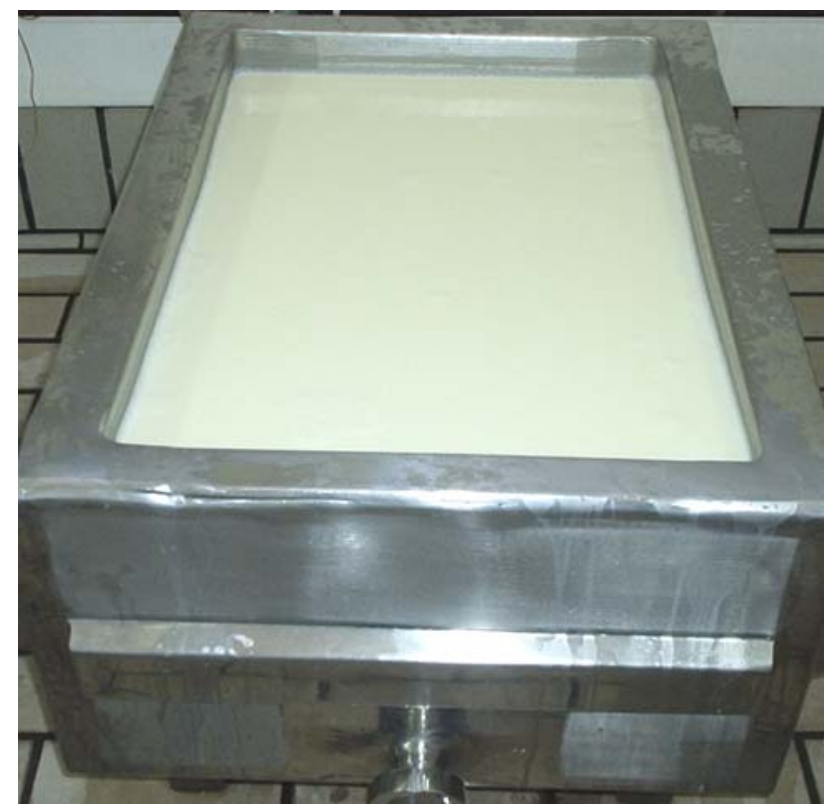

Figura 5. Repouso após adição de fermento.

Após coagulação, com auxílio de liras horizontal e vertical, foi realizado o corte em fragmentos de cerca de $1 \mathrm{~cm}$ de aresta. Em seguida foi realizado o tratamento da massa (Figura 6a), constituído de agitação lenta por dez minutos à temperatura de $34{ }^{\circ} \mathrm{C}$ e, consecutivamente, o pré-cozimento da massa (agitação e aumento da temperatura até $43{ }^{\circ} \mathrm{C}$ ) até atingir consistência desejada (Figura 6b). Passados três minutos de repouso, a amostragem de soro foi retirada para realização das análises físico-químicas, e em seguida realizada a dessoragem total (Figura 6c), pesando-o para fins de cálculos de rendimento ajustado.

A massa compacta (Figura 6d), restante no tanque, permaneceu fermentando por, aproximadamente, cinco horas à temperatura ambiente até atingir o ponto de filagem (Figura 6e). Em seguida, esta foi transferida para recipiente higienizado, coberta com filme plástico e mantida em câmara fria até o momento da filagem, realizada no dia seguinte.

A massa, retirada da câmara fria, foi cortada em tiras longas e delgadas. Estas foram trituradas e transferidas para um recipiente de inox contendo água próxima à fervura (80 - 85 
${ }^{\circ} \mathrm{C}$ ), para realização da filagem. A massa filada obtida, moldada manualmente, foi transferida para formas próprias, formato de paralelepípedo de quatro quilos, e mantidas em banho de água fria $\left(3-4{ }^{\circ} \mathrm{C}\right)$ por duas horas. Após este período, a massa de coágulo foi transferida para um tanque contendo salmoura a $20{ }^{\circ}$ Baumé, permanecendo em imersão por 20 horas, em câmara fria a $10{ }^{\circ} \mathrm{C}$. Após este procedimento, as peças foram dispostas em prateleiras de uma B.O.D a $4{ }^{\circ} \mathrm{C}$, para secagem por 48 - 72 horas, sendo ao final, amostradas e embaladas em sacos plásticos de polietileno, a vácuo (Figura 6f), mantidas em B.O.D. a $4{ }^{\circ} \mathrm{C}$ por 30 dias.

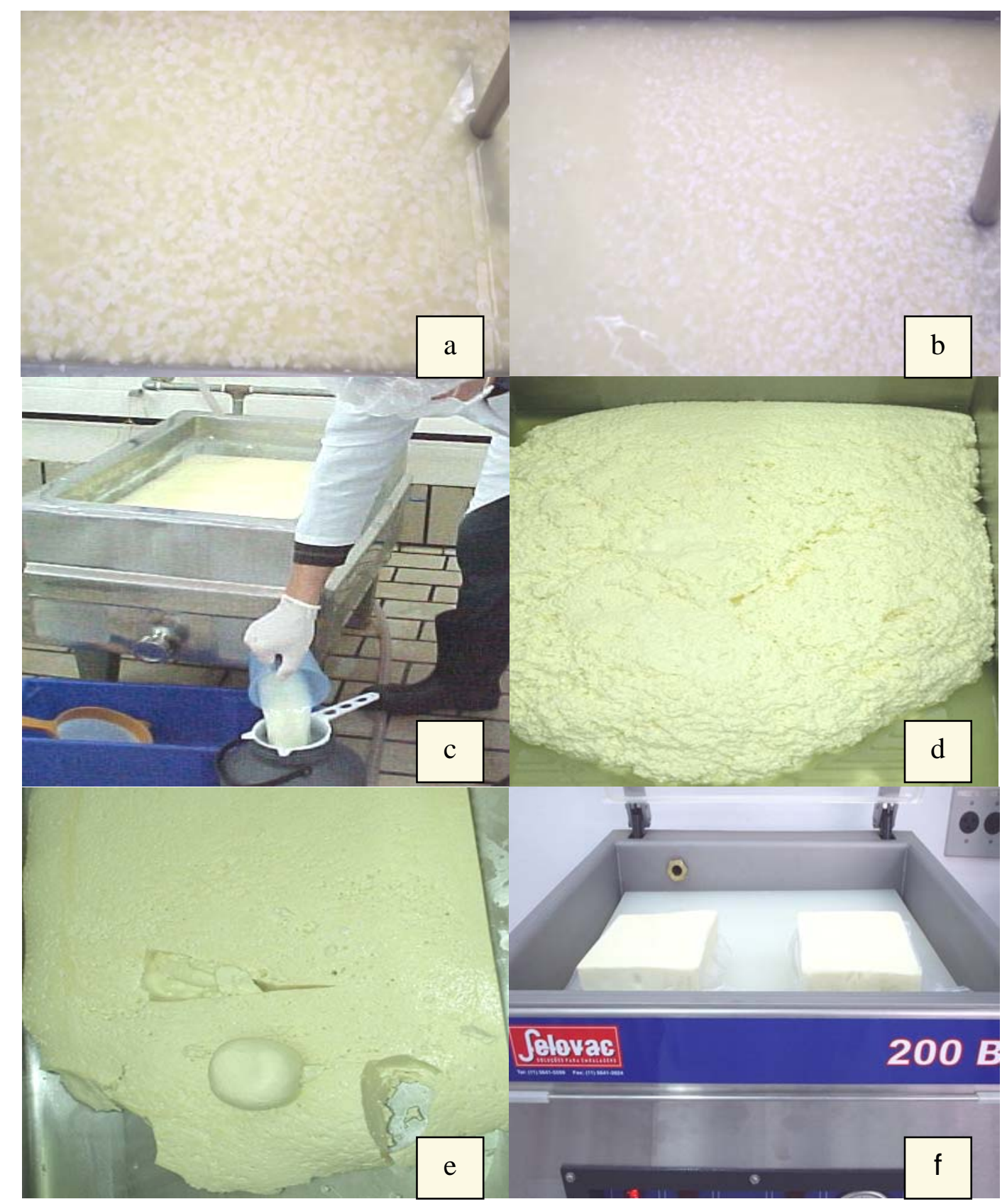

Figura 6. Etapas de fabricação do queijo tipo Mussarela. 
O procedimento de elaboração (Quadro 3) foi repetido três vezes para cada tratamento, totalizando, aproximadamente, 73 quilos de queijo tipo Mussarela.

Quadro 3. Fluxograma de fabricação do queijo tipo Mussarela

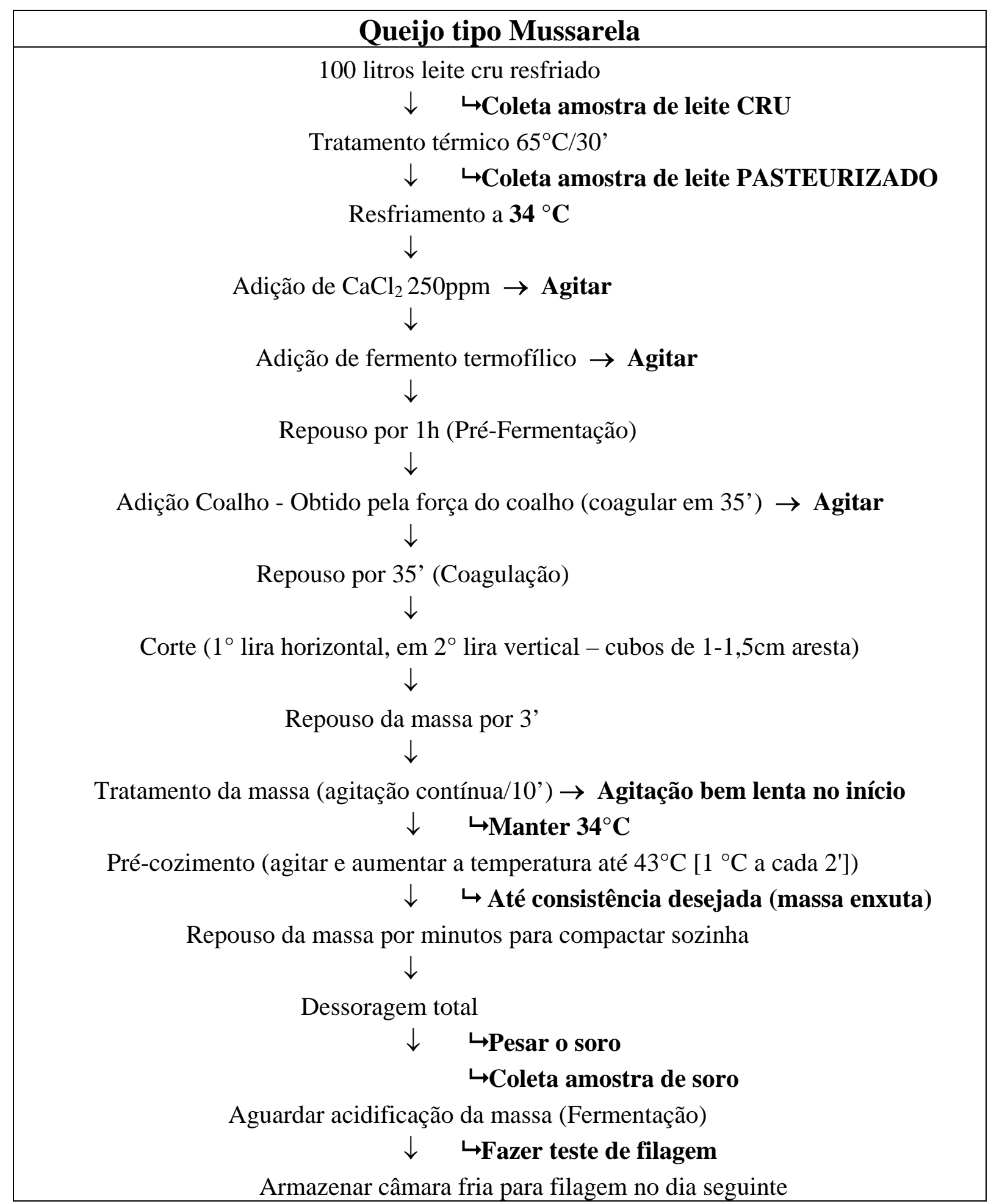




\subsubsection{Análises Laboratoriais dos Queijos Minas Frescal e tipo Mussarela}

As avaliações, descritas a seguir, foram realizadas nos dias 2, 9, 16, 23 e 30 após a fabricação dos queijos. Foram colhidas aleatoriamente duas amostras/tratamento para execução das análises, salvo para análises sensoriais.

\subsubsection{Avaliação Físico-química}

Imediatamente à abertura da embalagem, os queijos Minas frescal e tipo Mussarela foram macerados com pistilo e almofariz e triturados com mixer, respectivamente. Em seguida realizaram-se as determinações de $\mathrm{pH}$, através de um potenciômetro modelo Tec-2 (Tecnal); acidez titulável, obtida por cálculo do percentual de ácido lático na amostra a partir do valor obtido na titulação da mesma com indicador de fenolftaleína e $\mathrm{NaOH}$ 0,1 \% até atingir coloração rósea; percentual de gordura, obtido pelo método de Gerber (butirômetro especial para queijo); de matéria seca, obtida por estufa a $110{ }^{\circ} \mathrm{C} / 16 \mathrm{hs}$ e de cinzas, obtido por incineração em mufla a $550{ }^{\circ} \mathrm{C}$, segundo Brasil (1981).

\subsubsection{Avaliação da Proteólise}

A proteólise foi estimada através da relação caseína (C) / proteína verdadeira (PV), expressa em termos de nitrogênio $(\mathrm{N})$ - equivalente de proteína, cujos valores foram obtidos conforme descrito abaixo:

PV $=[$ Nitrogênio Total (NT) - Nitrogênio Não Protéico (NNP) ] x 6,38

C = [Nitrogênio Total (NT) - Nitrogênio Não Caseinoso (NNC)] x 6,38

A proteólise é também indicada pelos índices de extensão e profundidade. O índice de extensão está fundamentalmente relacionado com as proteinases naturais do leite e do agente coagulante, as quais degradam a proteína em peptídeos de alto peso molecular. O índice de profundidade de proteólise está relacionado principalmente com a atividade das endoenzimas e exoenzimas da cultura lática empregada na fabricação do queijo e de possíveis contaminantes, que degradam os peptídeos de baixo peso molecular.

Os índices foram obtidos através de cálculos descritos a seguir (WOLFSCHOON, 1983): 
Índice de Extensão da proteólise $(\%)=(\mathrm{NNC} / \mathrm{NT})$ x 100;

Índice de Profundidade da proteólise (\%) = (NNP / NT) x 100.

Para a determinação do NT, foi utilizado o método de Kjeldahl, conforme metodologia descrita pela Association of Official Analitycal Chemists (AOAC, 1995), discriminada a seguir. Em tubo macro-kjeldahl colocou-se $10 \mathrm{~g}$ de catalisador (sulfato de potássio, sulfato de cobre penta hidratado e selênio), 1,5 g de queijo macerado, pesado em papel manteiga, e 25 $\mathrm{mL}$ de ácido sulfúrico concentrado. Em seguida os tubos foram encaminhados para digestão, em bloco digestor, por aproximadamente cinco horas. Retirados os tubos do bloco, os mesmos foram encaminhados para a destilação. Adicionou-se a cada tubo, aproximadamente, $60 \mathrm{~mL}$ de água destilada, lavando a parede do tubo. Em seguida, realizou-se a destilação, neutralizando a amostra com $50 \mathrm{~mL}$ de $\mathrm{NaOH} 50 \%$, e recolheu-se $125 \mathrm{~mL}$ de destilado em erlenmeyer contendo $25 \mathrm{~mL}$ de ácido bórico 4 \% com indicador (vermelho de metila e verde de bromocresol). A titulação foi efetuada com ácido clorídrico $0,1 \mathrm{~N}$ até mudança de cor e permanência da mesma. Os valores obtidos foram multiplicados por 6,38 para obtenção da porcentagem de proteína total.

A determinação do NNP foi efetuada através de trituração da amostra de queijo, com auxílio de mixer, em $50 \mathrm{~mL}$ de ácido tricloroacético (TCA) a $12 \%$ e precipitação das proteínas, seguido de filtração, em papel filtro n. 1. O filtrado foi adicionado ao tubo macrokjeldahl, que continha a $10 \mathrm{~g}$ de catalisador e encaminhado para o processo de digestão, por cinco horas. Os tubos foram retirados do bloco e mantidos em temperatura ambiente até o momento da destilação. A cada tubo foi adicionado $60 \mathrm{~mL}$ de água destilada e encaminhado imediatamente à destilação, de acordo com método kjeldahl (AOAC, 1995).

A determinação do NNC também foi efetuada através de trituração da amostra de queijo, entretanto para esta análise foi utilizada, para precipitação da caseína, a solução trabalho $(\mathrm{pH}=4,6)$ composta de água destilada, acetato de sódio, cloreto de sódio, cloreto de cálcio e ácido acético, seguida de filtração, com papel filtro n. 1, digestão e destilação para obtenção do nitrogênio solúvel (AOAC, 1995).

\subsubsection{Avaliação da Lipólise}

O índice de lipólise do queijo foi obtido através da alteração nas concentrações de ácidos graxos livres (AGL) ao longo do período de estocagem. A determinação de AGL utilizou espectofotômetro e foi efetuada de acordo com a metodologia colorimétrica em 
espectofotômetro descrita por Shipe et al. (1980) e modificada por Ma, Barbano e Santos (2003). Utilizou-se ácido palmítico para a construção da curva de calibração, sendo o resultado expresso em meq AGL / kg de queijo (Figura 7).

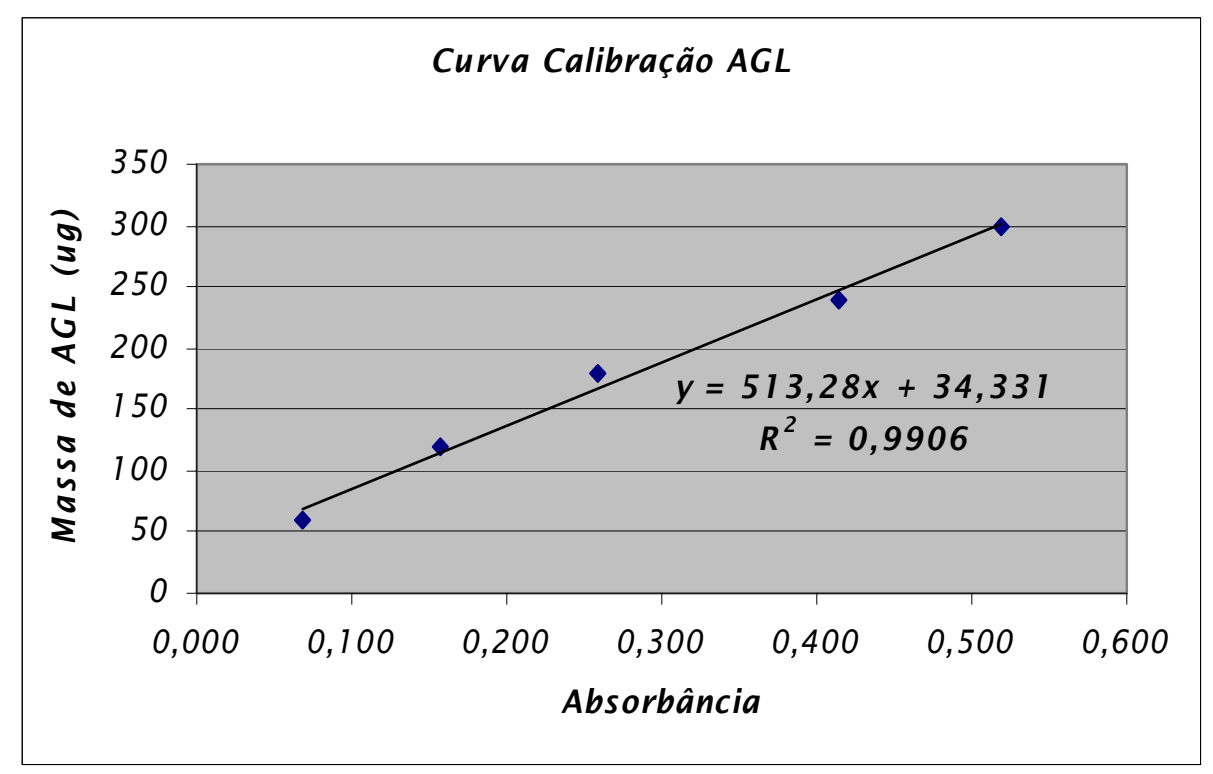

Figura 7. Curva de calibração padrão para análise de AGL dos queijos.

Para determinação da quantidade de AGL da amostra, 0,1 g de queijo macerado foi pesado, em tubo contendo 0,2 $\mathrm{mL}$ de solução de $\mathrm{HCl}$ 0,7 N, e armazenado por uma noite em B.O.D. No dia seguinte, foi adicionado $0,2 \mathrm{~mL}$ de solução Triton-X 100 e $4 \mathrm{~mL}$ de solução reagente de cobre (solução de trietanolamina e nitrato cúprico, com $\mathrm{pH}=8,3$ ) agitando entre as adições. Seguiu-se de acréscimo de $12 \mathrm{~mL}$ de solvente (clorofórmio:heptano:metanol na proporção de 49:49:2) e agitação contínua em mesa agitadora horizontal por 30 minutos. As amostras foram então centrifugadas por 10 minutos a 5000 rpm em centrífuga da marca Fanem (modelo $206 \mathrm{BL}$ ). Foi retirado 3,5 mL da porção transparente superior do tubo, usando micro-pipetador automático com ponteiras descartáveis, e transferido para um tubo de ensaio contendo 0,1 mL de reagente de cor. Após agitação, a mistura foi transferida para cubetas de vidro para leitura da absorbância usando espectrofotômetro (440nm).

\subsubsection{Avaliação Microbiológica}

A qualidade microbiológica foi avaliada através da contagem de microorganismos mesófilos, psicrotróficos, e determinação de coliformes a 30 e $45{ }^{\circ} \mathrm{C}$, de acordo com as técnicas preconizadas pela American Public Health Association (1992). Para cada tratamento foi utilizado um queijo, aberto, assepticamente, antes da pesagem e trituração da amostra em 
liquidificador de inox esterilizado. Utilizou-se $10 \mathrm{~g}$ de amostra e $90 \mathrm{~mL}$ de água peptonada para obtenção da diluição $10^{-1}$. A partir desta diluição foram realizadas as diluições subseqüentes, até $10^{-7}$, necessárias às análises de mesófilos, psicrotróficos e coliformes.

A contagem de microorganismos mesófilos e psicrotróficos foi realizada através de semeadura em profundidade utilizando Agar Padrão para Contagem (PCA), a partir da transferência de um mL das diluições para placas de Petri estéreis, em duplicata (Figura 8). As placas de mesófilos foram mantidas em estufa a $35{ }^{\circ} \mathrm{C}$ por 48 horas, enquanto que as placas de psicrotróficos foram estocadas em geladeira a $7{ }^{\circ} \mathrm{C}$ durante sete dias, para posterior contagem das colônias de bactérias em contador eletrônico.

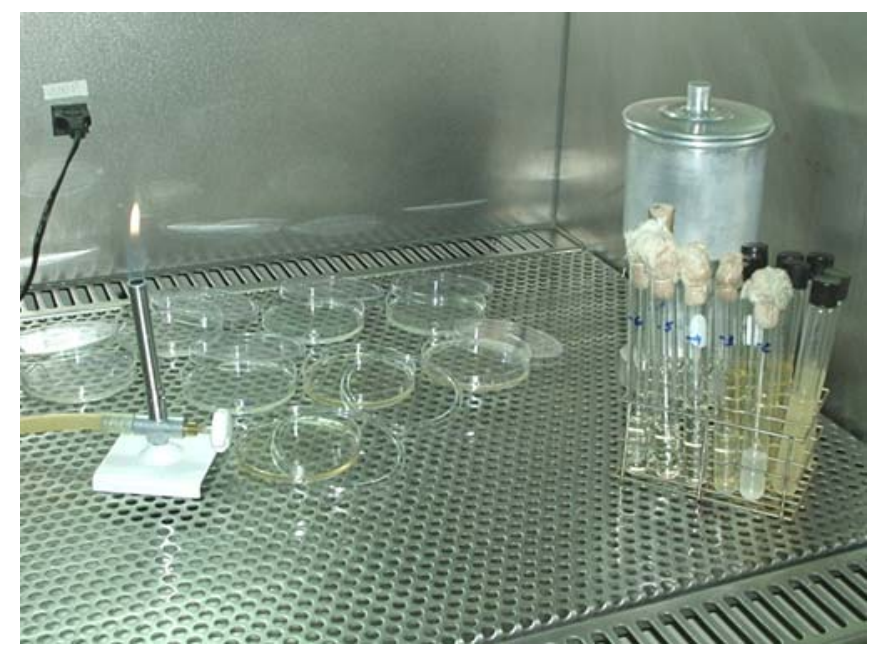

Figura 8. Análise Microbiológica do queijo.

A determinação de coliformes a $30^{\circ} \mathrm{C}$ se deu a partir das diluições $10^{-1}, 10^{-2}$ e $10^{-3}$ em água peptonada. Transferiu-se alíquotas de $1 \mathrm{~mL}$ para cada tubo de ensaio contendo tubos de Durhan invertidos, imersos em caldo lauril sulfato de sódio. Estes permaneceram em estufa a $35{ }^{\circ} \mathrm{C}$ por 48 horas. Dos tubos positivos, com presença de gás, foram transferidas amostras, com auxílio de alça de platina, para tubos contendo caldo EC, específico para Escherichia coli, e mantidos em banho-maria a $45^{\circ} \mathrm{C}$ por 24 horas, para obtenção de tubos com ou sem presença de gás como indicação ou não de coliformes a $45^{\circ} \mathrm{C}$ (coliformes fecais).

\subsubsection{Avaliação Sensorial}

Neste teste de aceitabilidade foram empregados os critérios estabelecidos por Amerine et al. (1967). As amostras de queijo foram analisadas nos dias 2, 9, 16, 23 e 30 após a fabricação, através de painel não treinado constituído por 50 provadores de acordo com o 
Institut of Food Technologists (IFT, 1981), os quais foram recrutados entre alunos, professores e funcionários do Campus da USP de Pirassununga. Os provadores atribuíram valores aos queijos, numa escala hedonística de nove pontos. Os formulários, de avaliação sensorial (Quadro 4 e 5), continham campos que possibilitavam aos provadores anotar descrições que julgassem importantes.

Quadro 4. Ficha para Avaliação da Aparência.

Produto testado: Queijo

Nome: Idade:

Data:

Por favor, avalie as amostras de queijo utilizando a escala abaixo para descrever o quanto você gostou ou desgostou, em relação ao atributo APARÊNCIA.
1- Desgostei muitíssimo
2- Desgostei muito
3- Desgostei regularmente
4- Desgostei ligeiramente
5- Indiferente
6- Gostei ligeiramente
7- Gostei regularmente
8- Gostei muito
9- Gostei muitíssimo

Por Favor, indique que característica (s) você gostou e/ou desgostou na amostra:

\begin{tabular}{|l|c|c|c|}
\hline $\begin{array}{c}\text { AMOSTRA } \\
\left(\mathrm{N}^{\circ}\right)\end{array}$ & $\begin{array}{c}\text { VALOR DA } \\
\text { ESCALA }\end{array}$ & GOSTEI & DESGOSTEI \\
\hline & - & - & - \\
\hline & - & - & - \\
\hline
\end{tabular}


Quadro 5. Ficha utilizada na Avaliação Sensorial dos Queijos para aroma, sabor, textura e aceitação global.

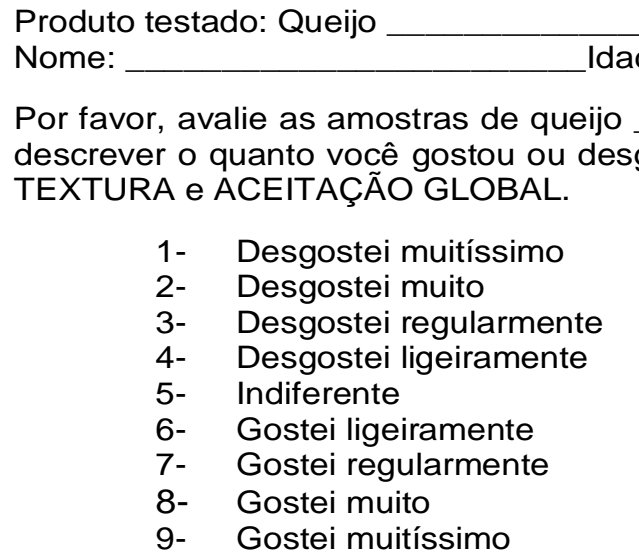

Por favor, avalie as amostras de queijo TEXTURA e ACEITAÇÃO GLOBAL.

1- Desgostei muitíssimo

2- Desgostei muito

3- Desgostei regularmente

4- Desgostei ligeiramente

5- Indiferente

6- Gostei ligeiramente

7- Gostei regularmente

8- Gostei muito

9- Gostei muitíssimo utilizando a escala abaixo para descrever o quanto você gostou ou desgostou, em relação aos atributos AROMA, SABOR,

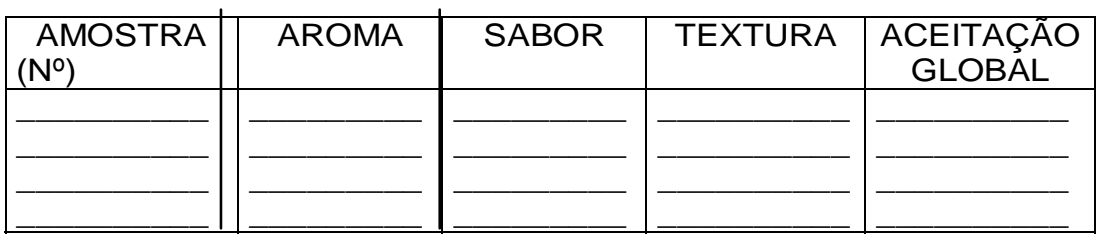

O que você mais gostou nas amostras?

O que você menos gostou nas amostras?

A amostra deixou algum sabor estranho na boca? Se sim, você pode descrever?

Você compraria esse produto?

Comentários:

As amostras foram submetidas ao teste de aceitabilidade em temperatura ambiente em porções de aproximadamente 25 g, servidas em pratos plásticos de cor branca, codificadas com números de quatro dígitos, e ordem de apresentação aleatória (Figura 9a). Para a avaliação da aparência foram utilizadas fatias, também apresentadas em pratos plásticos e codificadas (Figura 9b).

Os testes foram realizados no Laboratório de Análise Sensorial da Faculdade de Zootecnia e Engenharia de Alimentos (FZEA/USP), em cabines individuais utilizando-se luz branca. O horário da avaliação foi pela manhã entre as 8:00 e 12:00 horas. 


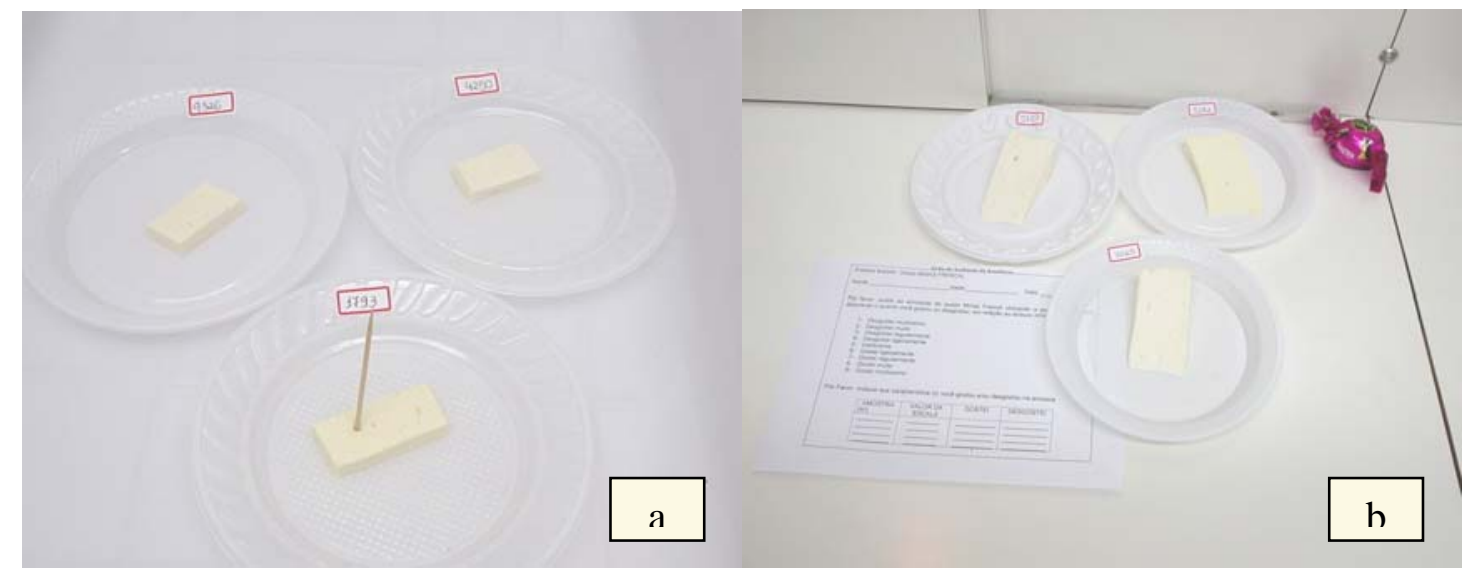

Figura 9. Avaliação Sensorial do queijo Minas Frescal.

\subsubsection{Avaliação do Rendimento}

O rendimento bruto da obtenção dos queijos nos diferentes tratamentos foi determinado pela fórmula $\mathrm{R}(\%)=(\mathrm{Pq} / \mathrm{Pf}) \times 100$, onde $\mathrm{R}=$ rendimento bruto, $\mathrm{Pq}=$ peso do queijo terminado e Pf = peso da formulação (leite acrescido dos ingredientes), de acordo com Yunes e Benedet (2000). Também foi obtido o rendimento ajustado, determinado de acordo com os critérios metodológicos descritos por Klei et al. (1998).

\subsubsection{Avaliação da Funcionalidade}

\subsection{Textura}

A textura, dos queijos Minas Frescal e tipo Mussarela, foi analisada a $10{ }^{\circ} \mathrm{C}$, através de teste de Força em compressão de $40 \%$ da altura da amostra e teste de análise do perfil de textura (TPA), respectivamente, utilizando texturômetro TAXT2i (Stable Micro Systems Godalming, Grã-Bretanha) (Figura 10) e pobre de acrílico 20 mm (CHAVES, 1997). Foi utilizado um queijo para cada dia de análise, sendo amostrado dez cilindros, obtidos através de sonda de inox de $20 \mathrm{~mm}$ de diâmetro. Os cilindros foram padronizados a altura de $20 \mathrm{~mm}$, com auxílio de cortador de ovos. Os mesmos foram embalados em filme plástico e estocados na B.O.D. até o momento da análise. Os dados foram analisados pelo programa Texture Expert, versão 1.0 para obtenção dos valores de firmeza dos queijos Minas Frescal e tipo Mussarela, além da elasticidade e mastigabilidade. 


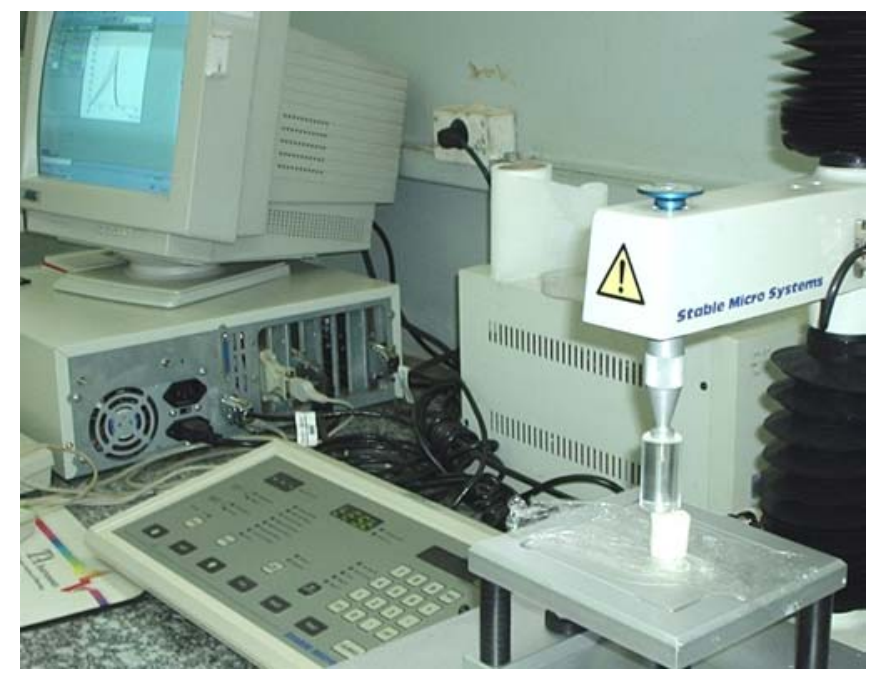

Figura 10. Texturômetro

\subsection{Capacidade de Derretimento - Queijo tipo Mussarela}

Para análise da capacidade de derretimento (C.D.) foi amostrado do queijo, com auxílio de uma sonda de $36 \mathrm{~mm}$ de diâmetro, um cilindro de $50 \mathrm{~mm}$ de altura. Deste, com auxílio de um cortador de queijos, foram obtidas quatro amostras cilíndricas, de $7 \mathrm{~mm}$ de altura e $36 \mathrm{~mm}$ de diâmetro, dispostas no centro de placas de Petri de vidro, marcadas com quatro linhas gerando ângulos de $45^{\circ}$ entre elas (Figura 11). As placas com as amostras, dispostas na prateleira da estufa permaneceram 30 minutos em temperatura ambiente e em seguida encaminhada à estufa a $107^{\circ} \mathrm{C}$ por sete minutos. Passado este tempo, a prateleira foi retirada da estufa e mantida a temperatura ambiente por mais 30 minutos para posterior leitura.

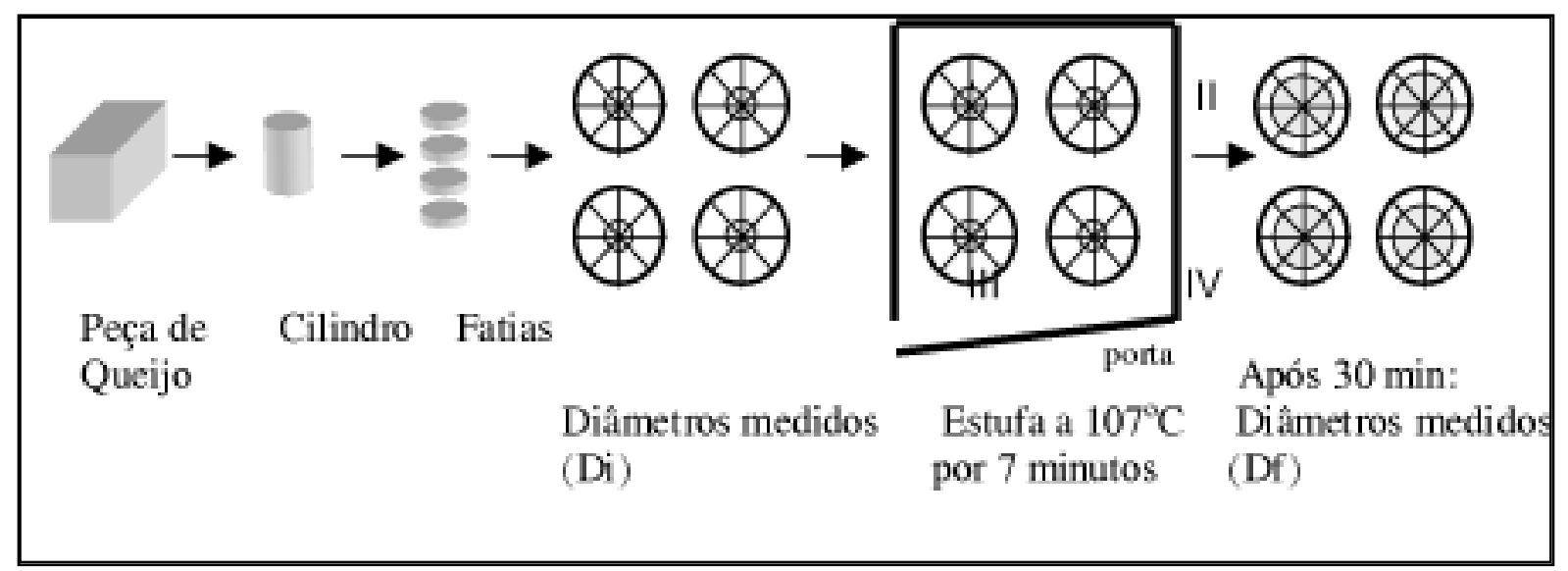

Figura 11. Esquema ilustrativo da análise da capacidade de derretimento. 
Os diâmetros do queijo derretido foram medidos com régua, calculada a média e a partir desta foi calculada a porcentagem de derretimento das amostras do queijo, segundo a equação a seguir. O procedimento foi realizado conforme descrito por Kosikowski (1982).

$$
\text { C.D. }(\%)=\frac{\mathrm{Df}^{2}-\mathrm{Di}^{2}}{\mathrm{Di}^{2}} \times 100
$$

onde:

Di = Diâmetro médio inicial da amostra (pré-derretimento);

Df = Diâmetro médio final da amostra (pós-derretimento).

\subsection{Determinação de Óleo Livre - Queijo tipo Mussarela}

As amostras foram analisadas em duplicata. A quantidade de óleo livre foi determinada pelo método de Gerber modificado conforme metodologia preconizada por Kindstedt e Fox (1991), descrita abaixo.

O queijo triturado foi armazenado em saco plástico a $4{ }^{\circ} \mathrm{C}$ até atingir temperatura constante. Pesou-se 6,0 g de amostra em tubo de tampa rosqueável e imediatamente estes foram encaminhados ao banho-maria, em água fervente, por quatro minutos. Posteriormente foi adicionado $10 \mathrm{~mL}$ de água acidificada $(\mathrm{pH}=2,2)$ a $60{ }^{\circ} \mathrm{C}, 10 \mathrm{~mL}$ de água destilada e metanol, centrifugado em centrífuga de Gerber e aquecido em banho-maria entre as adições para obtenção de uma camada amarela de óleo na superfície do metanol aquoso. Esta camada, juntamente com o metanol, foi transferida para butirômetro de Gerber e realizou-se aquecimento e centrifugação para leitura da coluna de gordura formada. A porcentagem de óleo livre foi obtida através de a equação a seguir.

\%óleo livre = média da gordura obtida na escala 


\subsection{Delineamento Experimental e Análise Estatística}

O delineamento experimental, para leite cru, leite pasteurizado e soro, foi blocos ao acaso, tendo como efeito do tratamento a contagem de células somáticas e efeito do bloco os processamentos com cinco lotes para o queijo Minas frescal e três lotes para o queijo tipo Mussarela. Os dados foram submetidos a análise de variância utilizando-se o procedimento proc glm do programa SAS (SAS, 2004), e as diferenças entre as médias foram testadas pelo teste de Tukey a 5\% de significância.

Para os queijos foi utilizado um delineamento experimental em parcelas subdivididas com blocos, considerando-se a contagem de células somáticas como efeito principal, os dias de análise como subparcelas e os processamentos como blocos com cinco lotes para o queijo Minas frescal e três lotes para o queijo tipo Mussarela. A análise estatística das características avaliadas, que envolveram medidas repetidas no tempo, foi realizada utilizando-se os procedimentos proc glm e proc mixed do programa SAS (SAS, 2004) para obtenção do estudo de regressão através de contrastes ortogonais e as diferenças foram testadas pelo teste de Tukey ao nível de 5\% de significância.

Os dados da análise sensorial, não paramétrica, foram analisados utilizando o Teste de Kruskal-Wallis. Uma posterior comparação dos tratamentos aos pares foi feita utilizando o Teste de Dunn, ao nível de 5\%. Nessas análises utilizou-se o pacote MINITAB. 


\section{RESULTADOS E DISCUSSÃO}

\subsection{Queijo Minas Frescal}

\subsubsection{Leite In Natura}

As médias da composição físico-química do leite cru utilizadas na fabricação dos queijos Minas frescal são apresentadas na Tabela 1. Para as características de acidez, pH, índice crioscópico, gordura, proteína, lactose, sólidos totais e sólidos não gordurosos não houve efeito significativo $(\mathrm{p}<0,05)$ entre os três tipos de leite, porém a densidade diferiu para o fator CCS. O leite com CCS >800.000 céls./mL apresentou maior densidade em relação ao leite de 100.000-200.000 céls./mL, não diferindo do leite de 400.000-500.000 céls./mL.

Como se pode observar, os valores, da análise físico-química nos níveis 100.000200.000 céls./mL e 400.000-500.000 céls./mL, estão próximos e dentro da faixa de normalidade (BRASIL, 2002). O queijo com CCS acima de 800.000 apresenta valores superiores em todas as características avaliadas. Isto se deve provavelmente à alimentação fornecida aos animais, pois este leite foi coletado em propriedade diferente dos demais. De acordo com Fonseca e Santos (2000), a composição do leite envolve os efeitos alimentação, manejo reprodutivo e herança genética, podendo assim ocorrer diferença no leite coletado.

Em relação à proteína, esta se apresenta em maior concentração no leite que contém mais de 800.000 células somáticas, fato este também comprovado por outros autores (KLEI et al., 1998; SOMERS et al., 2003). Entretanto, os resultados experimentais são conflitantes ao avaliar os efeitos de elevadas CCS no leite sobre a concentração de proteína total. De acordo com Auldist e Hublle (1998) deve-se levar em consideração que leite mastítico apresenta aumento na concentração de proteínas de origem sanguínea com concomitante redução na concentração de caseína do leite, que no final resulta em mínimas alterações na concentração de proteína total. Paape, Capuco e Guidry (1995) justificam esses aumentos na concentração de proteínas séricas possivelmente pela perda da integridade do epitélio mamário, devido à ação de toxinas bacterianas. 
Tabela 1 - Composição físico-química do leite cru, utilizado na fabricação de queijo Minas Frescal, de acordo com a contagem de células somáticas (CCS) ${ }^{1}$.

\begin{tabular}{|c|c|c|c|c|}
\hline & \multicolumn{3}{|c|}{ CCS no leite } & \multirow{2}{*}{ CV (\%) } \\
\hline & $100-200.000$ & $400-500.000$ & $>800.000$ & \\
\hline Densidade $\left(\mathrm{g} / \mathrm{cm}^{3}\right)$ & $1.027 \pm 0,0000^{b}$ & $1.027 \pm 0,0001^{\mathrm{ab}}$ & $1.028 \pm 0,0001^{\mathrm{a}}$ & 0,0045 \\
\hline Acidez $\left({ }^{\circ} \mathbf{D}\right)$ & $15,7 \pm 2,99$ & $15,0 \pm 1,17$ & $18,3 \pm 4,56$ & 16,40 \\
\hline pH & $6,74 \pm 0,05$ & $6,72 \pm 0,04$ & $6,67 \pm 0,12$ & 1,17 \\
\hline IC $\left({ }^{\circ} \mathrm{H}\right)$ & $0,532 \pm 0,002$ & $0,533 \pm 0,002$ & $0,530 \pm 0,002$ & 0,540 \\
\hline Gordura (\%) & $2,76 \pm 0,27$ & $2,71 \pm 0,28$ & $3,05 \pm 0,48$ & 10,89 \\
\hline Proteína (\%) & $2,69 \pm 0,10$ & $2,76 \pm 0,14$ & $2,88 \pm 0,21$ & 4,94 \\
\hline Lactose (\%) & $4,36 \pm 0,06$ & $4,28 \pm 0,11$ & $4,35 \pm 0,15$ & 2,26 \\
\hline ST (\%) & $10,82 \pm 0,28$ & $10,71 \pm 0,33$ & $11,25 \pm 0,50$ & 3,62 \\
\hline SNG (\%) & $8,06 \pm 0,15$ & $8,00 \pm 0,10$ & $8,20 \pm 0,18$ & 1,95 \\
\hline
\end{tabular}

1 Resultados relativos à média \pm desvio padrão de cinco repetições (processamentos), analisados em duplicata.

Na linha, médias seguidas de letras minúsculas diferentes diferem entre si pelo teste de Tukey a $5 \%$.

A Tabela 2 mostra o nível de contaminação bacteriológica presente nas amostras de leite cru utilizadas nos processamentos. Os valores médios de mesófilos, psicrotróficos e coliformes não diferiram para os níveis de CCS dos leites. Os mesófilos e psicrotróficos variaram de 5,89 a 6,51 log ufc/mL e 5,25 a 5,61 log ufc/mL, respectivamente. Já os valores de coliformes a $30{ }^{\circ} \mathrm{C}$ e $45{ }^{\circ} \mathrm{C}$ variaram de 1,70 a 2,04 log $\mathrm{NMP} / \mathrm{mL}$ e 0,37 a $0,52 \log$ $\mathrm{NMP} / \mathrm{mL}$. Todos os resultados apresentam-se dentro do limite máximo exigido pela legislação (BRASIL, 2001), permitindo assim, a utilização dos leites para o processamento do queijo Minas Frescal. 
Tabela 2. Análise microbiológica do leite cru, utilizado na fabricação de queijo Minas Frescal, de acordo com a contagem de células somáticas (CCS)1.

\begin{tabular}{ccccc}
\hline CCS no leite & $\begin{array}{c}\text { Mesófilos } \\
(\log \text { UFC/mL) }\end{array}$ & $\begin{array}{c}\text { Psicrotróficos } \\
(\log \text { UFC/mL) }\end{array}$ & $\begin{array}{c}\text { Coliformes 30 }{ }^{\mathbf{C}} \mathbf{C} \\
(\mathbf{N M P} / \mathbf{m L})\end{array}$ & $\begin{array}{c}\text { Coliformes } \mathbf{4 5}^{\mathbf{0}} \mathbf{C} \\
(\mathbf{N M P} / \mathbf{m L})\end{array}$ \\
\hline $\mathbf{1 0 0}-\mathbf{2 0 0 . 0 0 0}$ & $5,89 \pm 1,21$ & $5,27 \pm 1,38$ & $1,70 \pm 0,75$ & $0,52 \pm 0,71$ \\
$\mathbf{4 0 0}-\mathbf{5 0 0 . 0 0 0}$ & $6,18 \pm 1,14$ & $5,61 \pm 1,66$ & $1,96 \pm 0,17$ & $0,60 \pm 0,91$ \\
$>\mathbf{8 0 0 . 0 0 0}$ & $6,51 \pm 1,07$ & $5,25 \pm 1,48$ & $2,04 \pm 0,00$ & $0,37 \pm 0,73$ \\
\hline $\mathbf{C V ~ ( \% )}$ & $\mathbf{9 , 4 3}$ & $\mathbf{8 , 8 3}$ & $\mathbf{2 0 , 7 1}$ & $\mathbf{6 9 , 8 6}$
\end{tabular}

1 Resultados relativos à média \pm desvio padrão de cinco repetições (processamentos), analisados em duplicata.

Não foram observadas diferenças significativas pelo teste de Tukey a 5\%.

\subsubsection{Leite Pasteurizado}

Os resultados de $\mathrm{pH}$ e acidez, e microbiologia do leite pasteurizado, durante a fabricação do queijo Minas Frescal, encontram-se nas Tabelas 3 e 4, respectivamente. Não houve diferença significativa $(\mathrm{P}>0,05)$ para $\mathrm{pH}$ e acidez, bem como para as características microbiológicas, entre as diferentes contagens de células somáticas.

Tabela 3. Valores de acidez e pH do leite pasteurizado, utilizado na fabricação de queijo Minas Frescal, de acordo com a contagem de células somáticas (CCS) ${ }^{1}$.

\begin{tabular}{ccc}
\hline CCS no leite & Acidez $\left({ }^{\circ} \mathbf{D}\right)$ & pH \\
\hline $\mathbf{1 0 0}-\mathbf{2 0 0 . 0 0 0}$ & $14,0 \pm 0,12$ & $6,56 \pm 0,00$ \\
$\mathbf{4 0 0}-\mathbf{5 0 0 . 0 0 0}$ & $14,8 \pm 0,08$ & $6,52 \pm 1,35$ \\
$>\mathbf{8 0 0 . 0 0 0}$ & $15,8 \pm 0,14$ & $6,54 \pm 2,20$ \\
\hline $\mathbf{C V ~ ( \% )}$ & $\mathbf{9 , 5 2}$ & $\mathbf{1 , 1 2}$ \\
\hline
\end{tabular}

1 Resultados relativos à média \pm desvio padrão de cinco repetições (processamentos), analisados em duplicata.

Não foram observadas diferenças significativas pelo teste de Tukey a 5\%.

Os níveis de microrganismos mesófilos e psicrotróficos foram drasticamente diminuídos em todos os tipos de leite, além disso, observou-se a completa destruição de coliformes totais e coliformes fecais. Segundo Adad (2004) a pasteurização faz-se necessária como um pré-requisito para a fabricação de queijos, pois objetiva a eliminação de organismos patogênicos e outros que, embora não sejam patogênicos, são indesejáveis pelas más fermentações que podem ocasionar nos queijos. 
Tabela 4. Análise microbiológica do leite pasteurizado, utilizado na fabricação de queijo Minas Frescal, de acordo com a contagem de células somáticas (CCS)1.

\begin{tabular}{ccccc}
\hline CCS no leite & $\begin{array}{c}\text { Mesófilos } \\
(\mathbf{U F C} / \mathbf{m L})\end{array}$ & $\begin{array}{c}\text { Psicrotróficos } \\
\mathbf{( U F C / m L )}\end{array}$ & $\begin{array}{c}\text { Coliformes } 30^{\mathbf{}} \mathbf{C} \\
(\mathbf{N M P} / \mathbf{m L})\end{array}$ & $\begin{array}{c}\text { Coliformes } 45^{\mathbf{0}} \mathbf{C} \\
\mathbf{( N M P / m L )}\end{array}$ \\
\hline $\mathbf{1 0 0}-\mathbf{2 0 0 . 0 0 0}$ & $2,25 \pm 1,29$ & $0,91 \pm 1,26$ & Ausente & Ausente \\
$\mathbf{4 0 0}-\mathbf{5 0 0 . 0 0 0}$ & $2,66 \pm 0,66$ & $0,20 \pm 0,45$ & Ausente & Ausente \\
$>\mathbf{8 0 0 . 0 0 0}$ & $2,52 \pm 0,92$ & $0,91 \pm 1,25$ & Ausente & Ausente \\
\hline $\mathbf{C V ~ ( \% )}$ & $\mathbf{1 5 , 1 9}$ & $\mathbf{1 4 2 , 1 6}$ & - & - \\
\hline
\end{tabular}

1 Resultados relativos à média \pm desvio padrão de cinco repetições (processamentos), analisados em duplicata.

Não foram observadas diferenças significativas pelo teste de Tukey a 5\%.

O grau de aquecimento é amplamente controlado por enzimas, sendo que para a indústria existe a importância na avaliação da fosfatase alcalina e peroxidase, pois resultados negativos para fosfatase, e positivos para peroxidase indicam a eficiência do tratamento térmico utilizado. Portanto os resultados encontrados neste trabalho podem ser considerados satisfatórios indicando que os leites foram submetidos a um processamento térmico adequado.

\subsubsection{Soro}

Na Tabela 5 são apresentados os resultados médios das análises do soro obtido dos cinco processamentos realizados. Observou-se uma tendência de maior porcentagem de gordura presente no soro do queijo processado com maior nível de células somáticas, e o inverso para sólidos totais e sólidos não gordurosos. Todavia, não houve efeito significativo $(\mathrm{P}>0,05)$ para essas características em relação as diferentes contagens de células somáticas. 
Tabela 5. Resultados da análise físico-química do soro, de acordo com a contagem de células somáticas (CCS), dos processamentos de queijo Minas Frescal ${ }^{1}$.

\begin{tabular}{cccc}
\hline CCS no leite & Gordura (\%) & ST (\%) & SNG (\%) \\
\hline $\mathbf{1 0 0 - \mathbf { 2 0 0 . 0 0 0 }}$ & $0,47 \pm 0,08$ & $6,71 \pm 0,28$ & $6,24 \pm 0,24$ \\
$\mathbf{4 0 0}-\mathbf{5 0 0 . 0 0 0}$ & $0,48 \pm 0,15$ & $6,46 \pm 0,73$ & $5,98 \pm 0,64$ \\
$>\mathbf{8 0 0 . 0 0 0}$ & $0,55 \pm 0,16$ & $6,65 \pm 0,44$ & $6,10 \pm 0,45$ \\
\hline $\mathbf{C V ~ ( \% )}$ & $\mathbf{1 5 , 4 4}$ & $\mathbf{7 , 7 1}$ & $\mathbf{8 , 2 3}$ \\
\hline
\end{tabular}

${ }^{1}$ Resultados relativos à média \pm desvio padrão de cinco repetições (processamentos), analisados em duplicata.

Não foram observadas diferenças significativas pelo teste de Tukey a 5\%.

Ao analisar as perdas de gordura sofridas, nota-se que o queijo produzido com leite de alta CCS (>800.000 céls./mL) perdeu mais gordura que os demais, ocorrendo perdas de 17,0, 17,7 e 18,0\% para os queijos de 100.000-200.000 céls./mL, 400.000-500.000 céls/mL e >800.000 céls/mL, respectivamente. A perda média de gordura foi de 17,6\%, verificando-se perda excessiva em relação a média nacional, considerada normal entre 10 a 15 \%. Esta perda de gordura através do soro se dá em função da temperatura de pasteurização do leite, teor de cálcio e proteínas, acidez, pH e temperatura de adição do coalho, que afeta a coagulação do leite. Além destes há outros fatores como, a rapidez do corte, o tamanho dos grãos e a intensidade da agitação feita imediatamente após o corte, possuem forte influência nas perdas de gordura e proteínas do soro (O RENDIMENTO..., 2005). Diante disso, as referidas perdas podem ser minimizadas através da coagulação bem controlada do leite e de um corte cuidadoso da coalhada.

\subsubsection{Queijo Minas Frescal}

Os resultados das análises microbiológicas do queijo Minas Frescal são apresentados na Tabela 6. Verificou-se que os queijos produzidos com leite contendo CCS acima de 800.000 céls./mL apresentaram numericamente contagem de mesófilos superior após o $23^{\circ}$ dia, porém não houve efeito significativo $(\mathrm{P}>0,05)$ entre as diferentes contagens de células somáticas do leite. O mesmo ocorreu para contagem de psicrotróficos, porém apresentaram numericamente contagem superior aos demais queijos somente no $30^{\circ}$ dia de armazenamento. As contagens de coliformes totais $\left(30^{\circ} \mathrm{C}\right)$ também foram crescentes em todos os queijos, a partir do $9^{\circ}$ dia de análise. 
Os resultados estão de acordo com a legislação vigente (BRASIL, 1980), considerando-se o queijo Minas como queijo de massa crua não fermentada. Adicionalmente, não foram constatados níveis detectáveis de coliformes fecais $\left(45^{\circ} \mathrm{C}\right)$ nos queijos com baixa CCS (100.000-200.000 céls./mL) e média CCS (400.000-500.000 céls./mL), sendo que os queijos com alta CCS (> 800.000 céls./mL) apresentaram níveis abaixo de 100 NMP/g, conforme preconizado para este produto (BRASIL, 1980). Em síntese, os resultados indicaram que as características microbiológicas do queijo Minas frescal não foram afetadas pelos níveis de células somáticas no leite, e que também foram produzidos de acordo com os princípios das Boas Práticas de Fabricação.

Tabela 6. Resultados da análise microbiológica do queijo Minas Frescal, de acordo com a contagem de células somáticas (CCS) do leite cru1.

\begin{tabular}{|c|c|c|c|c|c|}
\hline \multicolumn{6}{|c|}{ Mesófilos (logUFC/g) ${ }^{*}$} \\
\hline CCS no leite & Dia 2 & Dia 9 & Dia 16 & Dia 23 & Dia 30 \\
\hline $100-200.000$ & $4,15 \pm 1,33$ & $5,04 \pm 0,93$ & $6,12 \pm 1,36$ & $6,24 \pm 1,64$ & $6,20 \pm 1,60$ \\
\hline $400-500.000$ & $4,41 \pm 0,66$ & $5,00 \pm 0,93$ & $5,87 \pm 1,01$ & $6,08 \pm 1,40$ & $6,39 \pm 1,36$ \\
\hline$>800.000$ & $4,18 \pm 0,68$ & $4,85 \pm 0,98$ & $5,81 \pm 1,42$ & $6,63 \pm 1,54$ & $7,21 \pm 1,44$ \\
\hline CV (\%) & \multicolumn{5}{|c|}{23,68} \\
\hline Regressão & \multicolumn{5}{|c|}{ Linear } \\
\hline \multicolumn{6}{|c|}{ Psicrotróficos (logUFC/g) ${ }^{*}$} \\
\hline CCS no leite & Dia 2 & Dia 9 & Dia 16 & Dia 23 & Dia 30 \\
\hline $100-200.000$ & $2,82 \pm 2,04$ & $4,81 \pm 1,09$ & $6,01 \pm 1,51$ & $5,72 \pm 1,65$ & $6,57 \pm 0,86$ \\
\hline $400-500.000$ & $3,32 \pm 2,04$ & $4,29 \pm 1,09$ & $5,37 \pm 1,51$ & $5,35 \pm 1,65$ & $6,20 \pm 0,86$ \\
\hline$>800.000$ & $2,59 \pm 2,04$ & $3,85 \pm 1,09$ & $5,28 \pm 1,51$ & $5,15 \pm 1,65$ & $6,69 \pm 0,86$ \\
\hline CV (\%) & \multicolumn{5}{|c|}{36,76} \\
\hline Regressão & \multicolumn{5}{|c|}{ Linear } \\
\hline sultados & IS >̀ & & & & \\
\hline
\end{tabular}

Para os níveis de mesófilos e psicrotróficos não houve interação entre os fatores CCS e dias de armazenamento, porém houve efeito significativo $(\mathrm{P}<0,05)$ para dias de armazenamento (Figura 12). Observou-se efeito linear positivo de mesófilos e psicrotróficos em relação aos dias de armazenamento, sendo que para cada acréscimo de um dia de 
armazenamento do queijo a quantidade de mesófilos e psicrotrófcos aumentam 0,608 e 0,825 $\log$ UFC/g, respectivamente. No entanto, Kasimoglu, Göncüoglu e Akgün (2004) ao fabricar queijo branco tradicional com cultura "start” (Lactococcus lactis ssp. Lactis e Lactococcus lactis ssp. Cremoris) e queijo com adição de L. acidophilus, verificaram maior quantidade de bactérias mesófilas aeróbicas em relação ao queijo do presente experimento, apresentando durante os 90 dias de armazenamentos valores acima de 9,0 log UFC/g, para o queijo branco Turco, havendo declínio do crescimento de bactérias mesofílicas após o $7^{\circ}$ dia de estocagem, ao contrário do observado neste experimento.

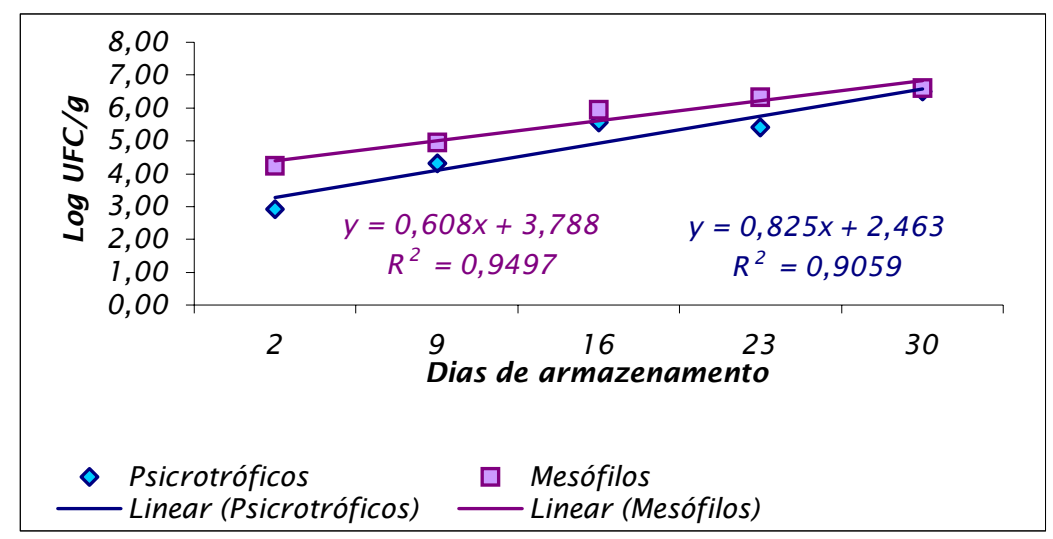

Figura 12. Avaliação de mesófilos e psicrotróficos em função dos dias de armazenamento.

As médias para as características físico-químicas em relação a CCS e dias de armazenamento são apresentadas na Tabela 7. Não houve interação entre CCS e dias de armazenamento $(\mathrm{P}>0,05)$ para todas as características avaliadas. Os resultados físicoquímicos obtidos em todos os lotes de queijo Minas Frescal estiveram de acordo com os parâmetros mínimos definidos na legislação brasileira para o produto, conforme sua classificação em queijo com alto teor de umidade (BRASIL, 2001).

Os resultados de $\mathrm{pH}$, gordura na base seca e cinzas mantiveram-se próximos durante o período de armazenamento. Os valores de $\mathrm{pH}$ em relação aos dias de armazenamento variaram de 6,80 para 6,79; de 6,78 a 6,71; e de 6,74 a 6,71 nos queijos de baixa, média e alta contagem de células somáticas, respectivamente, mas não apresentaram efeito significativo.

Para a acidez (\% de ácido lático) houve efeito $(\mathrm{P}<0,05)$ linear positivo para a CCS (Figura 13) e para dias de armazenamento (Figura 14), sendo que a cada aumento de uma célula somática/mL tem se um aumento de $0,025 \%$ de ácido lático no queijo. E para cada um dia de armazenamento tem-se o aumento de 0,053\% de ácido lático no queijo. 
De acordo com Fox, Lucey e Cogan (1990) o decréscimo nos valores de pH ao longo do tempo é devido à fermentação de lactose do queijo, com a formação de ácido lático. Este fato pode ser verificado ao analisar os resultados obtidos para acidez.

A matéria seca do queijo apresentou efeito $(\mathrm{P}<0,05)$ linear positivo em relação aos dias de armazenamento, sendo que a medida que passa o tempo de estocagem ocorre perda de umidade dos queijos.

Tabela 7. Resultados das análises físico-químicas do queijo Minas Frescal, de acordo com a contagem de células somáticas (CCS) no leite $\mathrm{cru}^{1}$.

\begin{tabular}{|c|c|c|c|c|c|}
\hline \multicolumn{6}{|c|}{ PH } \\
\hline CCS no leite & Dia 2 & Dia 9 & Dia 16 & Dia 23 & Dia 30 \\
\hline $100-200.000$ & $6,80 \pm 0,13$ & $6,77 \pm 0,13$ & $6,75 \pm 0,12$ & $6,76 \pm 0,12$ & $6,79 \pm 0,16$ \\
\hline $400-500.000$ & $6,78 \pm 0,15$ & $6,79 \pm 0,13$ & $6,74 \pm 0,12$ & $6,80 \pm 0,15$ & $6,71 \pm 0,11$ \\
\hline$>800.000$ & $6,74 \pm 0,18$ & $6,77 \pm 0,10$ & $6,66 \pm 0,20$ & $6,74 \pm 0,20$ & $6,71 \pm 0,13$ \\
\hline CV (\%) & \multicolumn{5}{|c|}{2,16} \\
\hline Regressão & \multicolumn{5}{|c|}{ ns } \\
\hline \multicolumn{6}{|c|}{ Acidez (\% ácido lático) } \\
\hline CCS no leite & Dia 2 & Dia 9 & Dia 16 & Dia 23 & Dia 30 \\
\hline $100-200.000$ & $0,30 \pm 0,1$ & $0,34 \pm 0,2$ & $0,32 \pm 0,1$ & $0,32 \pm 0,1$ & $0,54 \pm 0,3$ \\
\hline $400-500.000$ & $0,28 \pm 0,1$ & $0,38 \pm 0,1$ & $0,34 \pm 0,2$ & $0,44 \pm 0,2$ & $0,54 \pm 0,3$ \\
\hline$>800.000$ & $0,28 \pm 0,1$ & $0,44 \pm 0,2$ & $0,36 \pm 0,1$ & $0,38 \pm 0,2$ & $0,58 \pm 0,3$ \\
\hline CV (\%) & \multicolumn{5}{|c|}{49,18} \\
\hline Regressão & \multicolumn{5}{|c|}{ Linear } \\
\hline
\end{tabular}

\section{Gordura na base seca (\%)}

\begin{tabular}{cccccc}
\hline CCS no leite & Dia 2 & Dia 9 & Dia 16 & Dia 23 & Dia 30 \\
\hline $\mathbf{1 0 0 - \mathbf { 2 0 0 . 0 0 0 }}$ & $58,90 \pm 4,94$ & $60,65 \pm 6,77$ & $65,58 \pm 5,59$ & $61,48 \pm 5,92$ & $60,65 \pm 1,73$ \\
$\mathbf{4 0 0 - 5 0 0 . 0 0 0}$ & $61,58 \pm 2,76$ & $64,10 \pm 3,06$ & $60,12 \pm 4,99$ & $62,12 \pm 5,83$ & $64,38 \pm 3,93$ \\
$>\mathbf{8 0 0 . 0 0 0}$ & $58,75 \pm 6,49$ & $64,52 \pm 4,34$ & $63,52 \pm 4,86$ & $62,88 \pm 3,62$ & $66,15 \pm 2,93$ \\
\hline CV (\%) & & $\mathbf{7 , 6 0}$ & & \\
\hline Regressão & & ns & & \\
\hline
\end{tabular}


Tabela 7. Resultados das análises físico-químicas do queijo Minas Frescal, de acordo com a contagem de células somáticas (CCS) no leite cru (Continuação).

\begin{tabular}{|c|c|c|c|c|c|}
\hline \multicolumn{6}{|c|}{ PT (\%) } \\
\hline CCS no leite & Dia 2 & Dia 9 & Dia 16 & Dia 23 & Dia 30 \\
\hline $100-200.000$ & $16,94 \pm 0,92$ & $15,01 \pm 0,10$ & $15,46 \pm 1,04$ & $16,07 \pm 0,66$ & $15,15 \pm 1,31$ \\
\hline $400-500.000$ & $14,85 \pm 0,89$ & $16,04 \pm 0,48$ & $15,63 \pm 2,50$ & $14,90 \pm 1,97$ & $15,25 \pm 1,84$ \\
\hline$>800.000$ & $15,69 \pm 1,57$ & $14,89 \pm 1,03$ & $15,71 \pm 1,55$ & $15,60 \pm 1,81$ & $15,12 \pm 0,66$ \\
\hline CV (\%) & \multicolumn{5}{|c|}{8,96} \\
\hline Regressão & \multicolumn{5}{|c|}{ ns } \\
\hline \multicolumn{6}{|c|}{ MS (\%) } \\
\hline CCS no leite & Dia 2 & Dia 9 & Dia 16 & Dia 23 & Dia 30 \\
\hline $100-200.000$ & $36,95 \pm 2,96$ & $35,75 \pm 3,05$ & $35,97 \pm 3,37$ & $38,48 \pm 2,62$ & $37,93 \pm 0,81$ \\
\hline $400-500.000$ & $37,98 \pm 1,92$ & $38,14 \pm 1,47$ & $39,75 \pm 0,80$ & $39,44 \pm 1,32$ & $39,31 \pm 3,03$ \\
\hline$>800.000$ & $39,43 \pm 4,94$ & $37,89 \pm 4,05$ & $38,66 \pm 2,26$ & $40,58 \pm 3,55$ & $38,80 \pm 4,37$ \\
\hline CV (\%) & \multicolumn{5}{|c|}{7,74} \\
\hline Regressão & \multicolumn{5}{|c|}{ Linear } \\
\hline
\end{tabular}

Cinzas (\%)

\begin{tabular}{cccccc}
\hline CCS no leite & Dia 2 & Dia 9 & Dia 16 & Dia 23 & Dia 30 \\
\hline $\mathbf{1 0 0 - \mathbf { 2 0 0 . 0 0 0 }}$ & $4,23 \pm 0,34$ & $3,83 \pm 0,50$ & $3,89 \pm 0,62$ & $4,20 \pm 0,66$ & $4,23 \pm 0,82$ \\
$\mathbf{4 0 0 - \mathbf { 5 0 0 . 0 0 0 }}$ & $3,89 \pm 0,48$ & $3,74 \pm 0,38$ & $4,31 \pm 1,02$ & $4,20 \pm 0,67$ & $4,46 \pm 1,43$ \\
$>\mathbf{8 0 0 . 0 0 0}$ & $4,16 \pm 1,12$ & $3,86 \pm 0,73$ & $3,90 \pm 0,57$ & $4,07 \pm 0,38$ & $4,08 \pm 1,02$ \\
\hline
\end{tabular}

CV (\%) 19,33

\section{Regressão}

ns

1 Resultados relativos à média \pm desvio padrão de cinco repetições (processamentos), analisadas em duplicata nos dias 2, 9, 16, 23 e 30 após a fabricação.

* Médias de características significativas $(\mathrm{P}<0,05)$ segundo análise de regressão.

Em pesquisa realizada por Cunha et al (2002), que avaliaram o efeito da concentração do leite por ultrafiltração na composição e proteólise do queijo Minas Frescal, os resultados apresentaram-se inferiores a todos os parâmentros estudados no presente experimento, sendo que na primeira avaliação, após dois dias de fabricação, os valores foram 6,45 (pH), 0,17\% (acidez), 8,48\% (gordura na base seca), 23,33\% (proteína), 33,56\% (MS) e 3,80\% de cinzas. 
Porém, a acidez sofreu alteração estatística significativa com o tempo, comportamento semelhante ao encontrado neste experimento, verificando que, à medida que aumenta os dias de armazenamento, também aumenta a porcentagem de ácido lático dos queijos.

Estas variações estão diretamente ligadas à degradação da lactose residual do queijo Minas Frescal, pois como o queijo foi fabricado sem a adição de fermento lático, a glicólise resultante deve ser resultado do crescimento da flora natural do leite resistente à pasteurização ou de microorganismos contaminantes.

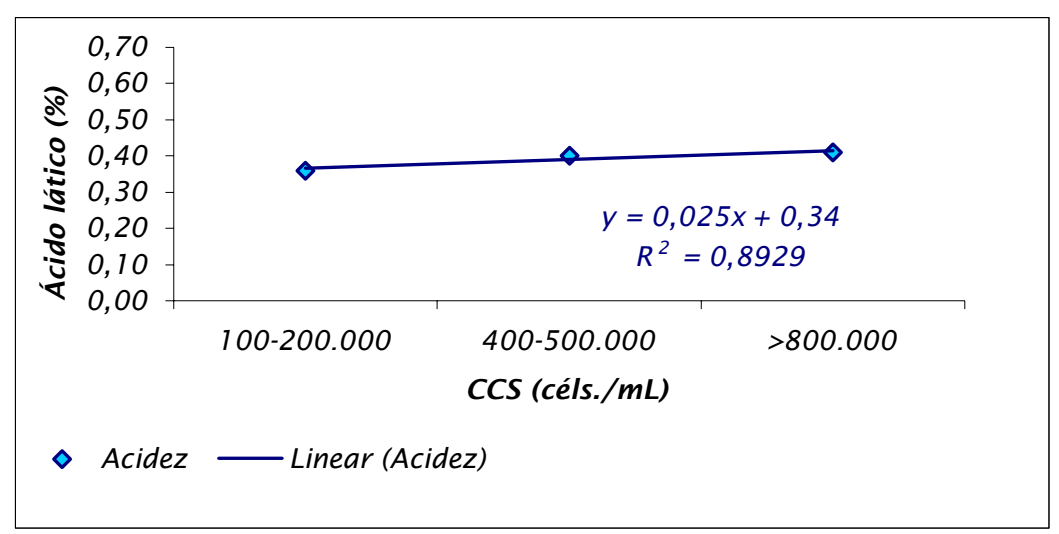

Figura 13. Avaliação da acidez em função da quantidade de células somáticas dos queijos Minas Frescal.

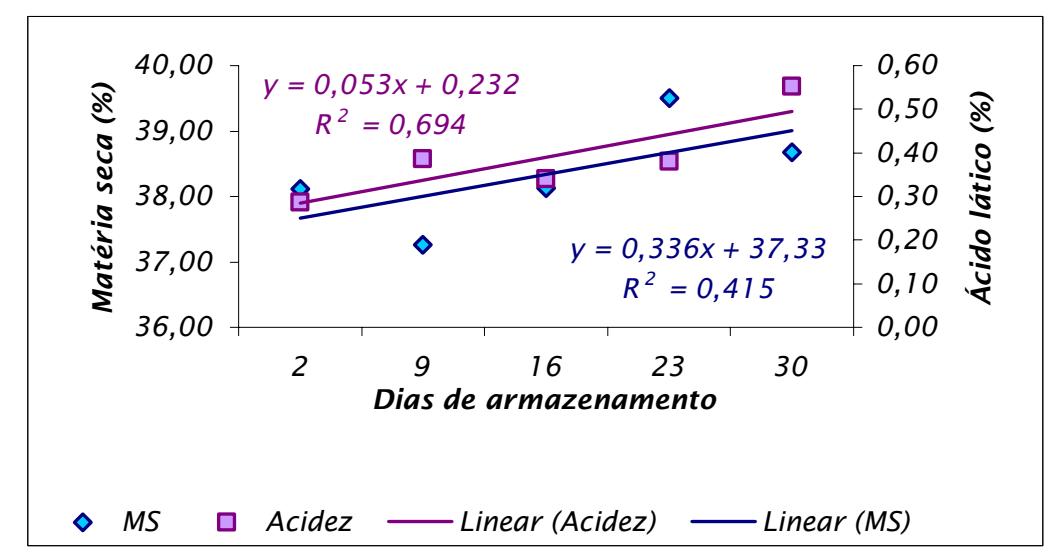

Figura 14. Avaliação da acidez e matéria seca dos queijos Minas Frescal em função dos dias de armazenamento. 
Os índices de proteólise, extensão e profundidade da proteólise são apresentados na Tabela 8. Para os índices de proteólise e extensão da proteólise houve interação entre CCS e dias de armazenamento. O queijo produzido com leite de alta CCS (>800.000 céls/mL) apresentou crescimento de proteólise mais acentuado que os demais queijos estudados, variando de 1,09 a 1,16 até o final do armazenamento, mesmo comportamento apresentado pela extensão da proteólise.

Este resultado concorda com os dados relatados na literatura indicando que a proteólise aumenta com o aumento da CCS, sendo que as proteases associadas com elevada CCS prejudicam a qualidade queijos e leite pasteurizado ao longo da vida de prateleira (SENYK et al., 1985). Já a profundidade da proteólise não sofreu efeito significativo (P>0,05) algum. As Figuras 15 e 16 ilustram a interação entre CCS e dias de armazenamento para índices de proteólise e extensão da proteólise.

Tabela 8. Valores do índice de proteólise, extensão e profundidade da proteólise do queijo Minas Frescal, de acordo com a contagem de células somáticas (CCS) no leite $\mathrm{cru}^{1}$.

\section{Proteólise $^{*}$}

\begin{tabular}{cccccc}
\hline CCS no leite & Dia 2 & Dia 9 & Dia 16 & Dia 23 & Dia 30 \\
\hline $\mathbf{1 0 0 - \mathbf { 2 0 0 . 0 0 0 }}$ & $1,10 \pm 0,02$ & $1,16 \pm 0,02$ & $1,09 \pm 0,03$ & $1,13 \pm 0,001$ & $1,13 \pm 0,03$ \\
$\mathbf{4 0 0 - 5 0 0 . 0 0 0}$ & $1,13 \pm 0,03$ & $1,13 \pm 0,05$ & $1,12 \pm 0,02$ & $1,13 \pm 0,05$ & $1,12 \pm 0,04$ \\
$>\mathbf{8 0 0 . 0 0 0}$ & $1,09 \pm 0,03$ & $1,13 \pm 0,04$ & $1,14 \pm 0,04$ & $1,14 \pm 0,05$ & $1,16 \pm 0,05$ \\
\hline CV (\%) & & $\mathbf{3 , 0 8}$ & \\
\hline Regressão & & Linear & \\
\hline
\end{tabular}

Profundidade da Proteólise

\begin{tabular}{cccccc}
\hline CCS no leite & Dia 2 & Dia 9 & Dia 16 & Dia 23 & Dia 30 \\
\hline $\mathbf{1 0 0 - \mathbf { 2 0 0 . 0 0 0 }}$ & $2,51 \pm 1,03$ & $2,47 \pm 1,36$ & $3,12 \pm 0,66$ & $2,22 \pm 0,96$ & $1,81 \pm 0,62$ \\
$\mathbf{4 0 0 - \mathbf { 5 0 0 . 0 0 0 }}$ & $2,17 \pm 0,25$ & $1,76 \pm 0,14$ & $1,78 \pm 0,82$ & $1,83 \pm 0,92$ & $2,42 \pm 1,53$ \\
$>\mathbf{8 0 0 . 0 0 0}$ & $1,70 \pm 0,35$ & $1,93 \pm 0,51$ & $2,04 \pm 0,83$ & $2,67 \pm 0,70$ & $3,70 \pm 1,66$ \\
\hline $\mathbf{C V ~ ( \% ) ~}$ & & $\mathbf{4 0 , 7 6}$ & \\
\hline Regressão & & $\mathbf{n s}$ & \\
\hline
\end{tabular}


Tabela 8. Valores do índice de proteólise, extensão e profundidade da proteólise do queijo Minas Frescal, de acordo com a contagem de células somáticas (CCS) no leite $\mathrm{cru}^{1}$. (Continuação).

\begin{tabular}{cccccc}
\hline \multicolumn{5}{c}{ Extensão da Proteólise $^{*}$} \\
\hline CCS no leite & Dia 2 & Dia 9 & Dia 16 & Dia 23 & Dia 30 \\
\hline $\mathbf{1 0 0 - \mathbf { 2 0 0 . 0 0 0 }}$ & $11,51 \pm 0,95$ & $15,91 \pm 0,88$ & $11,28 \pm 2,47$ & $13,44 \pm 1,79$ & $12,91 \pm 1,88$ \\
$\mathbf{4 0 0}-\mathbf{5 0 0 . 0 0 0}$ & $13,51 \pm 2,78$ & $13,22 \pm 3,53$ & $12,39 \pm 0,86$ & $13,53 \pm 2,93$ & $12,90 \pm 4,00$ \\
$>\mathbf{8 0 0 . 0 0 0}$ & $9,81 \pm 2,34$ & $12,69 \pm 3,30$ & $13,67 \pm 3,61$ & $14,64 \pm 3,71$ & $16,65 \pm 3,72$ \\
\hline CV (\%) & & $\mathbf{2 1 , 1 5}$ & & \\
\hline Regressão & & Linear & \\
\hline
\end{tabular}

${ }^{1}$ Resultados relativos à média \pm desvio padrão de três repetições (processamentos), analisadas em duplicata nos dias 2, 9, 16, 23 e 30 após a fabricação.

* Médias de características significativas $(\mathrm{P}<0,05)$ segundo análise de regressão

A proteólise é indicada pelo aumento dos índices de extensão e profundidade no decorrer do tempo (NARIMATSU et al., 2003). O índice de extensão está fundamentalmente relacionado com as proteinases naturais do leite e do agente coagulante, as quais degradam a proteína em peptídeos de alto peso molecular, enquanto o índice de profundidade está relacionado principalmente com a atividade de endoenzimas e exoenzimas da cultura lática empregada na fabricação do queijo e de possíveis contaminantes, que degradam os peptídeos de baixo peso molecular. Este fato justifica os resultados apresentados, pois nestes processamentos não foi utilizada cultura lática, logo a ausência de cultura lática contribui para a ação das proteinases naturais presentes. 


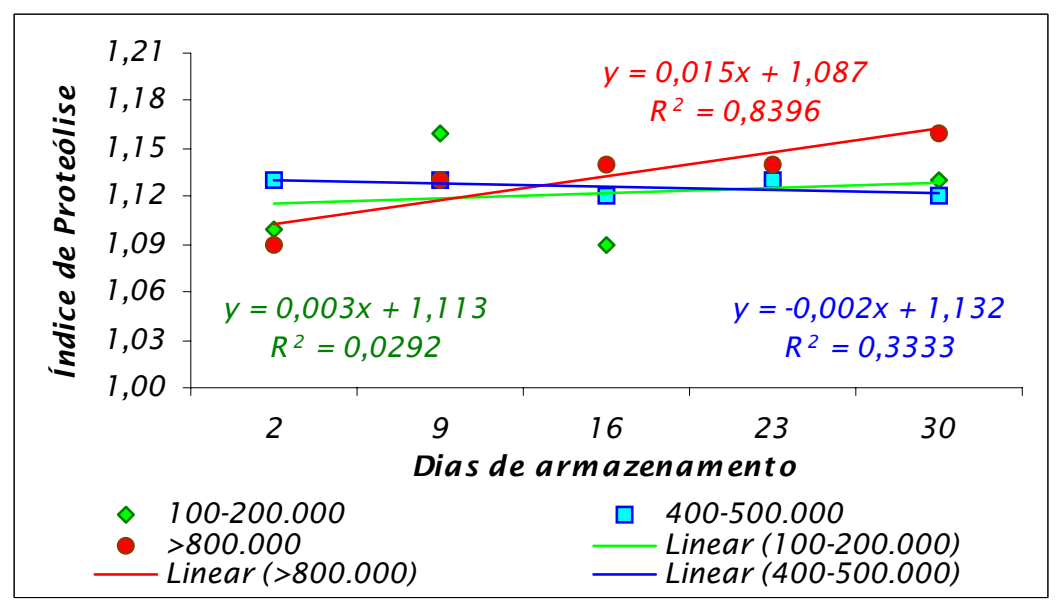

Figura 15. Evolução do índice de proteólise dos queijos durante o armazenamento. ( ) A: 100-200.000 céls./mL; ( $\square$ ) B: 400-500.000 céls./mL; (o) C: > 800.000 céls./mL.

De acordo com Kasumoglu, Göncüoglu e Akgün (2004) a proteólise é o caminho mais importante para o desenvolvimento do sabor e aroma do queijo branco Turco, pois verificaram que ao adicionar probiótico (L. acidophilus) houve um maior nível de proteólise, e desenvolvimento de bom aroma e sabor nos queijos.

Em pesquisa realizada por Cunha et al. (2004) o comportamento crescente do índice de extensão da proteólise ao longo do tempo foi semelhante ao do presente trabalho, porém, estes autores encontraram valores iniciais inferiores aos apresentados, variando de 5,5 a 20,5\%. Para isto, os altos índices de extensão encontrados podem estar relacionados à alta umidade dos queijos Minas, pois maiores teores de água favorecem as reações enzimáticas, entre elas a ação hidrolítica da quimosina (FOX, 1989), que é o principal responsável pela proteólise primária no queijo Minas.

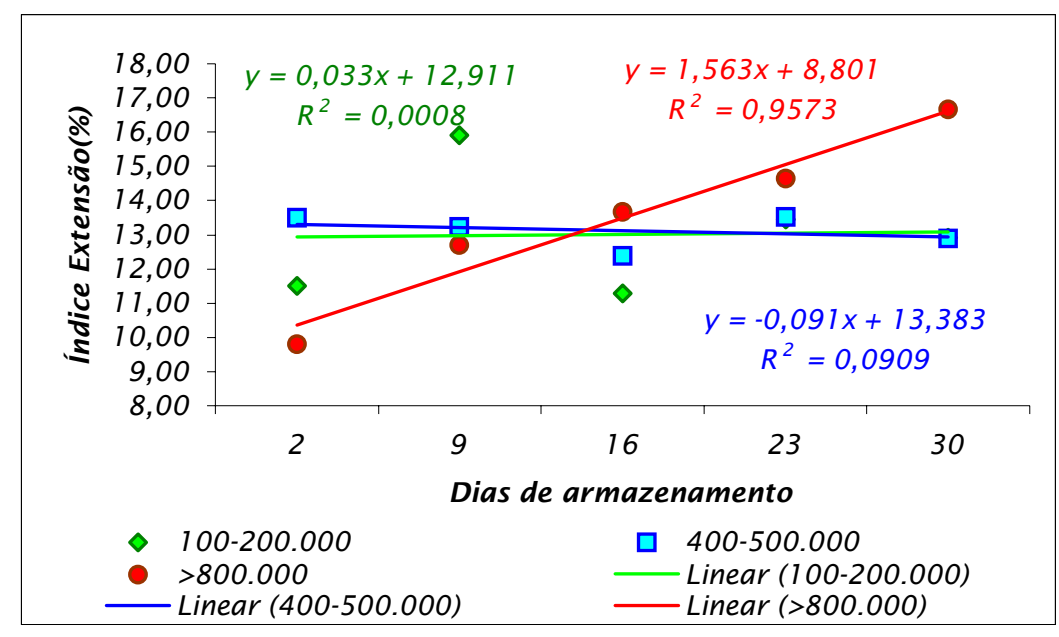

Figura 16. Evolução da extensão da proteólise dos queijos durante o armazenamento. ( ) A: 100-200.000 céls./mL; ( $\square$ ) B: 400-500.000 céls./mL; (o) C: > 800.000 céls./mL. 
A lipólise é um processo em que as enzimas lipolíticas hidrolisam a gordura, produzindo ácidos graxos livres e glicerol. Sendo assim, a lipólise do queijo foi estimada através da alteração nas concentrações de ácidos graxos livres (AGL) no produto ao longo do período de estocagem, sendo os resultados apresentados na Tabela 9.

Verificou-se que para esta característica não houve interação entre CCS e dias de armazenamento, assim como não houve efeito de CCS $(\mathrm{P}>0,05)$ e dias de armazenamento $(\mathrm{P}>0,05)$. As concentrações de AGL foram sempre superiores nos queijos produzidos com maiores níveis de células somáticas, indicando que a atividade lipolítica do queijo Minas com alta CCS aumenta durante o tempo de armazenamento, podendo levar a alterações sensoriais no produto, conforme descrito por outros autores (RANDOLPH; ERWIN, 1974; KITCHEN, 1981; STEFFET, 1993).

Muir (1996) e Downey (1980) concluíram que os AGL, principalmente os de cadeia curta, são os responsáveis por defeitos de sabor no leite. De acordo com Kasumoglu, Göncüoglu e Akgün (2004) os AGL e peptídeos de cadeia curta são necessários para o desenvolvimento do aroma e sabor, porém os consideram dependentes da extensão da proteólise.

Oliveira et al (2002) ao trabalhar com iogurte produzido com altas CCS no leite verificaram uma maior concentração de AGL e também menores notas de sabor. Como pode ser verificado abaixo, os valores de AGL para este experimento também apresentaram-se superiores para o queijo produzido com leite de alta CCS, porém as notas de sabor foram inversas, exceto no $30^{\circ}$ dia de armazenamento..

Tabela 9. Concentrações de ácidos graxos livres (AGL) do queijo Minas Frescal, de acordo com a contagem de células somáticas (CCS) do leite cru1.

\begin{tabular}{|c|c|c|c|c|c|}
\hline \multirow{2}{*}{ CCS no leite } & \multicolumn{5}{|c|}{ Concentração de AGL (meq/L) $)^{2}$} \\
\hline & Dia 2 & Dia 9 & Dia 16 & Dia 23 & Dia 30 \\
\hline $100-200.000$ & $2,00 \pm 0,45$ & $2,14 \pm 0,73$ & $2,12 \pm 0,63$ & $2,33 \pm 0,67$ & $2,31 \pm 0,72$ \\
\hline $400-500.000$ & $1,96 \pm 0,71$ & $2,26 \pm 0,83$ & $2,28 \pm 0,70$ & $2,39 \pm 0,94$ & $2,28 \pm 0,73$ \\
\hline$>800.000$ & $2,32 \pm 0,81$ & $2,73 \pm 1,06$ & $2,93 \pm 0,63$ & $2,63 \pm 0,72$ & $2,56 \pm 0,78$ \\
\hline CV (\%) & \multicolumn{5}{|c|}{32,07} \\
\hline Regressão & \multicolumn{5}{|c|}{ ns } \\
\hline \multicolumn{6}{|c|}{$\begin{array}{l}1 \text { Resultados relativos à média } \pm \text { desvio padrão de cinco repetições (processamentos), } \\
\text { analisadas em duplicata nos dias } 2,9,16,23 \text { e } 30 \text { após a fabricação. } \\
2 \text { Expresso em ácido palmítico. } \\
\text { Não foram observadas diferenças significativas pelo teste de Tukey a 5\%. }\end{array}$} \\
\hline
\end{tabular}


A análise de firmeza do queijo Minas Frescal de acordo com a CCS do leite cru é apresentada na Tabela 10.

Não houve interação entre CCS e dias de armazenamento, porém esta característica sofreu efeito $(\mathrm{P}<0,05)$ linear positivo para dias de armazenamento, sendo que para cada aumento de um dia de armazenamento tem-se um aumento de 74,71g de força. Logo, o aumento desta propriedade pode ter sido conseqüência da ligeira desidratação dos queijos, constatada pela elevação do percentual de MS, conforme apresentado na Tabela 7.

Verifica-se numericamente, que queijos produzidos a partir de leite com altas CCS apresentaram valores de firmeza inferiores aos demais queijos. Tal fato se deve possivelmente à maior proteólise que ocorreu no queijo de CCS acima de 800.000 céls/mL. Tal resultado também foi encontrado por Furtado et al. (1980), porém estes trabalharam com diferentes processos, observando alteração mais sensível somente no processo com fermento em que o corpo, anteriormente firme, se mostra frágil no $6^{\circ}$ dia de armazenamento, não havendo alteração nos processos tradicional e com ácido.

Tabela 10. Valores de firmeza do queijo Minas Frescal, de acordo com a contagem de células somáticas (CCS) do leite $\mathrm{cru}^{1}$.

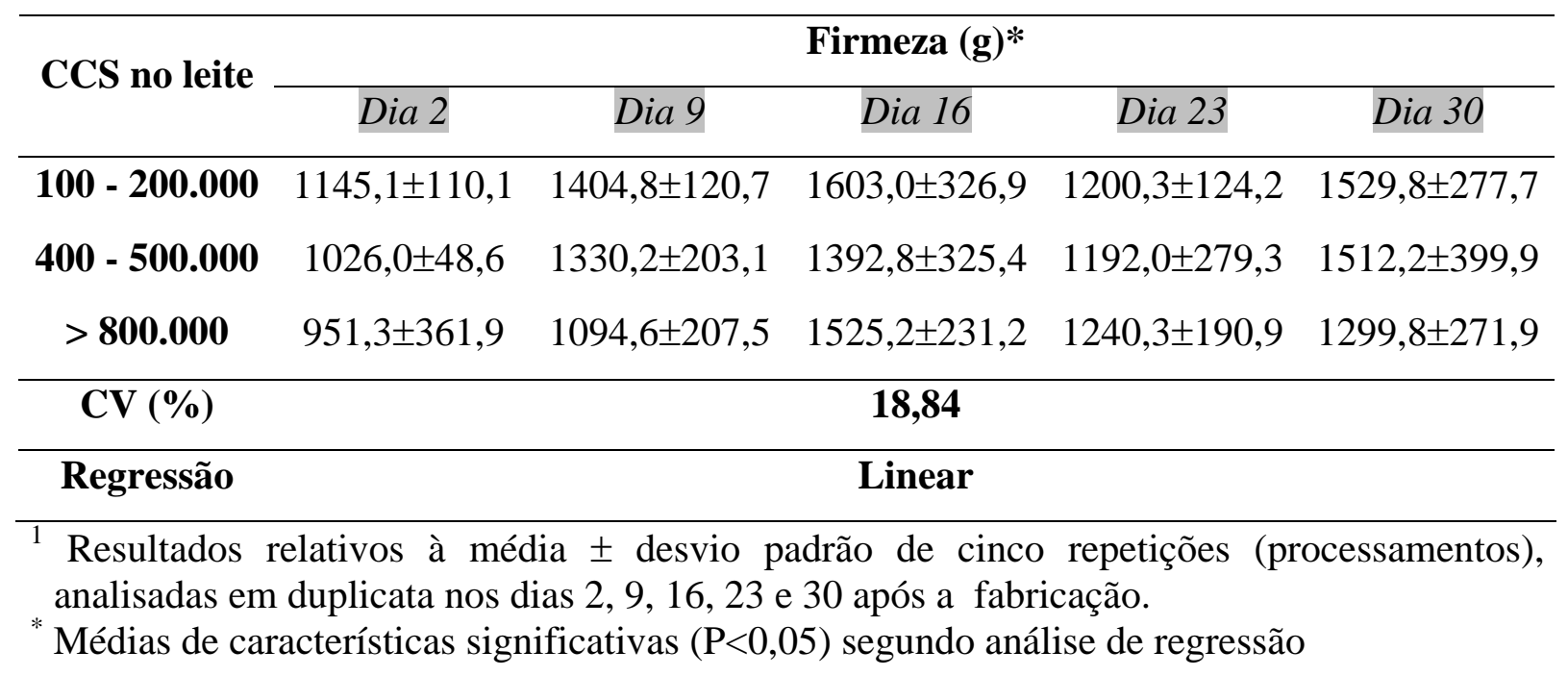




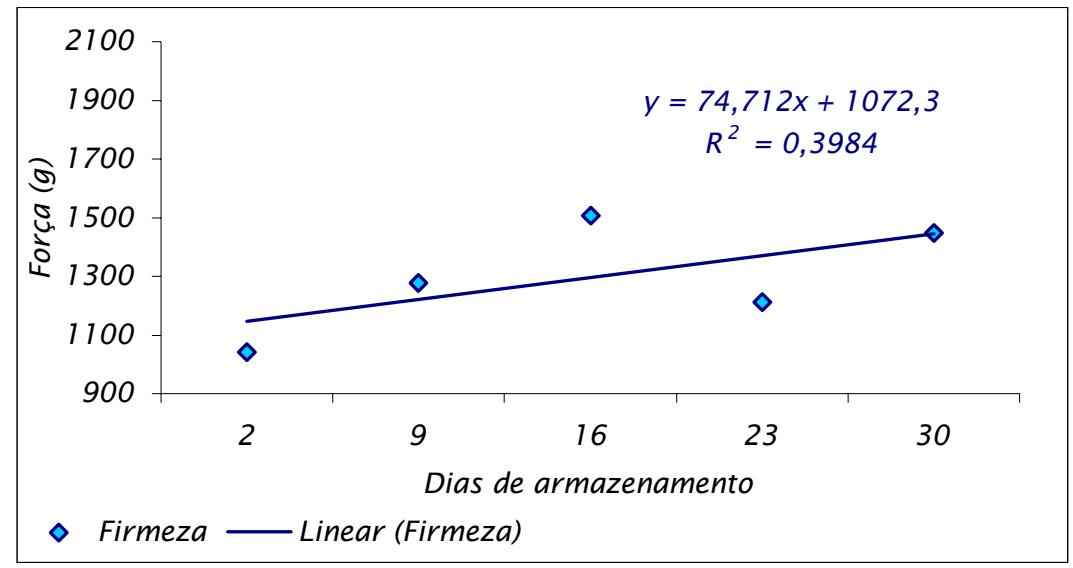

Figura 17. Avaliação da firmeza do queijo Minas Frescal em função dos dias de armazenamento.

A Tabela 11 apresenta os resultados obtidos na análise sensorial do queijo Minas Frescal nos dias 2, 9, 16, 23 e 30. Os atributos avaliados foram, conforme previsto, aroma, sabor, textura, aparência e aceitação global do produto.

Na avaliação, observou-se que no primeiro dia de análise, não houve diferença significativa para estas características, com exceção da aceitação global. Os queijos produzidos com alta CCS apresentaram notas inferiores aos demais em quase todos os atributos no dia 30. Este resultado demonstra que níveis de CCS acima de 800.000 céls./mL podem determinar alterações nas características sensoriais do queijo Minas Frescal ao longo do armazenamento, conforme observado por outros autores utilizando queijo Cheddar (POLITIS; NG-KWAI-HANG, 1988a,b,c). ROGERS e MITCHELL (1994) encontraram resultados semelhantes ao deste experimento, ao estudarem a relação entre contagem de células somáticas na qualidade do queijo Cheddar, verificando notas inferiores para sabor no decorrer dos dias de estocagem para os leites com CCS acima de 500.000 céls./mL

De acordo com Kasumoglu, Göncüoglu e Akgün (2004) durante o armazenamento do queijo branco Turco produzido com probiótico (L. acidophilus) houve um maior nível de proteólise, bem como desenvolvimento de bom aroma e sabor nos queijos.

Oliveira et al. (2002) ao avaliarem iogurtes produzidos com níveis diferentes de CCS verificaram que os iogurtes com alta CCS (> 800.000 céls. $/ \mathrm{mL}$ ) receberam notas inferiores para sabor em todos os dias de armazenamento. O mesmo não ocorreu neste experimento, apresentando notas superiores durante o armazenamento, exceto no $30^{\circ}$ dia de análise. 
Tabela 11. Valores de aroma, sabor, textura, aparência e aceitação global do queijo Minas frescal $^{1}$, de acordo com a contagem de células somáticas (CCS).

\section{Aroma}

\begin{tabular}{|c|c|c|c|c|c|}
\hline CCS no leite & Dia 2 & Dia 9 & Dia 16 & Dia 23 & Dia 30 \\
\hline $100-200.000$ & $5,5 \pm 1,44^{\mathrm{a}}$ & $7,0 \pm 1,47^{\mathrm{a}}$ & $6,0 \pm 1,53^{\mathrm{a}}$ & $6,0 \pm 1,82^{\mathrm{a}}$ & $6,0 \pm 1,50^{a}$ \\
\hline $400-500.000$ & $6,0 \pm 1,50^{\mathrm{a}}$ & $7,0 \pm 1,62^{\mathrm{a}}$ & $6,0 \pm 1,47^{\mathrm{a}}$ & $6,0 \pm 1,63^{\mathrm{a}}$ & $6,0 \pm 1,54^{a}$ \\
\hline$>800.000$ & $7,0 \pm 1,39^{\mathrm{a}}$ & $7,0 \pm 1,63^{\mathrm{a}}$ & $6,0 \pm 1,71^{\mathrm{a}}$ & $6,5 \pm 1,45^{\mathrm{a}}$ & $4,5 \pm 2,16^{b}$ \\
\hline
\end{tabular}

\section{Sabor}

\begin{tabular}{cccccc}
\hline CCS no leite & Dia 2 & Dia 9 & Dia 16 & Dia 23 & Dia 30 \\
\hline $\mathbf{1 0 0 - \mathbf { 2 0 0 . 0 0 0 }}$ & $8,0 \pm 1,61^{\mathrm{a}}$ & $7,0 \pm 1,58^{\mathrm{b}}$ & $6,0 \pm 1,82^{\mathrm{a}}$ & $6,0 \pm 2,21^{\mathrm{b}}$ & $6,0 \pm 2,01^{\mathrm{a}}$ \\
$\mathbf{4 0 0 - \mathbf { 5 0 0 . 0 0 0 }}$ & $7,0 \pm 1,72^{\mathrm{a}}$ & $7,0 \pm 1,80^{\mathrm{b}}$ & $6,0 \pm 1,86^{\mathrm{a}}$ & $7,0 \pm 2,01^{\mathrm{b}}$ & $6,0 \pm 1,65^{\mathrm{a}}$ \\
$>\mathbf{8 0 0 . 0 0 0}$ & $7,5 \pm 1,70^{\mathrm{a}}$ & $8,0 \pm 1,50^{\mathrm{a}}$ & $6,5 \pm 1,96^{\mathrm{a}}$ & $8,0 \pm 1,37^{\mathrm{a}}$ & $3,0 \pm 2,36^{\mathrm{b}}$ \\
\hline $\mathbf{C V ~ ( \% )}$ & & $\mathbf{3 0 , 6 0}$ & &
\end{tabular}

\begin{tabular}{cccccc}
\hline \multicolumn{5}{c}{ Textura } \\
\hline CCS no leite & Dia 2 & Dia 9 & Dia 16 & Dia 23 & Dia 30 \\
\hline $\mathbf{1 0 0 - \mathbf { 2 0 0 . 0 0 0 }}$ & $8,0 \pm 1,50^{\mathrm{a}}$ & $7,0 \pm 1,45^{\mathrm{a}}$ & $7,0 \pm 1,43^{\mathrm{a}}$ & $7,0 \pm 1,78^{\mathrm{a}}$ & $6,0 \pm 1,83^{\mathrm{ab}}$ \\
$\mathbf{4 0 0}-\mathbf{5 0 0 . 0 0 0}$ & $7,0 \pm 1,69^{\mathrm{a}}$ & $7,0 \pm 1,56^{\mathrm{a}}$ & $7,0 \pm 1,52^{\mathrm{a}}$ & $7,0 \pm 1,88^{\mathrm{a}}$ & $7,0 \pm 1,42^{\mathrm{a}}$ \\
$>\mathbf{8 0 0 . 0 0 0}$ & $8,0 \pm 1,41^{\mathrm{a}}$ & $8,0 \pm 1,41^{\mathrm{a}}$ & $7,0 \pm 1,62^{\mathrm{a}}$ & $7,0 \pm 1,78^{\mathrm{a}}$ & $6,0 \pm 2,22^{\mathrm{b}}$ \\
\hline $\mathbf{C V} \mathbf{( \% )}$ & & $\mathbf{2 4 , 8 8}$ & \\
\hline
\end{tabular}

\section{Aparência}

\begin{tabular}{cccccc}
\hline CCS no leite & Dia 2 & Dia 9 & Dia 16 & Dia 23 & Dia 30 \\
\hline $\mathbf{1 0 0 - \mathbf { 2 0 0 . 0 0 0 }}$ & $7,0 \pm 1,59^{\mathrm{a}}$ & $7,0 \pm 1,43^{\mathrm{a}}$ & $7,0 \pm 1,40^{\mathrm{a}}$ & $7,0 \pm 1,58^{\mathrm{a}}$ & $7,0 \pm 0,90^{\mathrm{a}}$ \\
$\mathbf{4 0 0 - \mathbf { 5 0 0 . 0 0 0 }}$ & $7,0 \pm 1,38^{\mathrm{a}}$ & $7,0 \pm 1,35^{\mathrm{a}}$ & $7,0 \pm 1,33^{\mathrm{a}}$ & $7,0 \pm 1,41^{\mathrm{a}}$ & $7,0 \pm 1,57^{\mathrm{b}}$ \\
$>\mathbf{8 0 0 . 0 0 0}$ & $7,0 \pm 1,36^{\mathrm{a}}$ & $7,0 \pm 2,09^{\mathrm{a}}$ & $6,0 \pm 1,89^{\mathrm{b}}$ & $5,5 \pm 1,85^{\mathrm{b}}$ & $6,0 \pm 1,77^{\mathrm{c}}$ \\
\hline $\mathbf{C V ~ ( \% )}$ & & $\mathbf{2 3 , 9 5}$ & & \\
\hline
\end{tabular}


Tabela 11. Valores de aroma, sabor, textura, aparência e aceitação global do queijo Minas frescal $^{1}$, de acordo com a contagem de células somáticas (CCS).

\section{Aceitação Global}

\begin{tabular}{cccccc}
\hline CCS no leite & Dia 2 & Dia 9 & Dia 16 & Dia 23 & Dia 30 \\
\hline $\mathbf{1 0 0 - \mathbf { 2 0 0 . 0 0 0 }}$ & $7,0 \pm 1,37^{\mathrm{a}}$ & $7,0 \pm 1,31^{\mathrm{a}}$ & $7,0 \pm 1,56^{\mathrm{a}}$ & $6,0 \pm 1,97^{\mathrm{b}}$ & $6,0 \pm 1,79^{\mathrm{a}}$ \\
$\mathbf{4 0 0}-\mathbf{5 0 0 . 0 0 0}$ & $7,0 \pm 1,52^{\mathrm{a}}$ & $7,0 \pm 1,45^{\mathrm{b}}$ & $7,0 \pm 1,51^{\mathrm{a}}$ & $7,0 \pm 1,85^{\mathrm{a}}$ & $6,0 \pm 1,52^{\mathrm{a}}$ \\
$>\mathbf{8 0 0 . 0 0 0}$ & $7,0 \pm 1,41^{\mathrm{a}}$ & $7,5 \pm 1,26^{\mathrm{b}}$ & $6,0 \pm 1,64^{\mathrm{a}}$ & $7,0 \pm 1,31^{\mathrm{a}}$ & $4,0 \pm 2,22^{\mathrm{b}}$ \\
\hline $\mathbf{C V ~ ( \% ) ~}$ & & $\mathbf{2 6 , 0 4}$ & &
\end{tabular}

${ }^{1}$ Resultados relativos à mediana \pm desvio padrão.

a,b.c Médias seguidas de diferentes letras nas colunas diferem estatisticamente pelo teste de Dunn a 5\%.

Machado et al. (2004) avaliaram as características sensoriais do queijo Minas artesanal produzido na região do Serro, com nove dias de fabricação, utilizando também o teste de aceitação com escala hedônica de nove pontos, e verificaram que a média da nota atribuída por trinta julgadores foi 6,03, definida como "gostei ligeiramente do produto”. Entretanto este valor foi considerado baixo, uma vez que este queijo é conhecido pela sua boa aceitação pelo mercado consumidor.

Londoño (1998) trabalhando com queijo Minas meia-cura em comparação com queijo Minas padrão e prato, também realizou análise sensorial. Porém, foi utilizado o teste de painel sensorial treinado através de Análise Descritiva Quantitativa. O queijo foi caracterizado como sendo de casca fina, aroma levemente pronunciado, consistência macia, textura levemente cremosa e levemente ácido. Outro estudo avaliando queijo Minas, porém curado, foi realizado por Barros (2001), que ao utilizar escala hedônica de cinco pontos, encontrou valor médio de 3,3. Santos et al. (1992) encontraram, utilizando escala hedônica de nove pontos, valor médio de 6,49 para o queijo Minas. Enquanto Ferreira et al. (1992) encontraram médias de 7,43 para queijos Minas fabricados a partir de culturas comerciais importadas e 7,57 para queijos Minas semi-curados, fabricados a partir de leite pasteurizado e salga na massa e tempo de armazenamento de 13 dias.

A Figura 18 demonstra que o leite obtido de vacas com alta CCS, tanto para rendimento bruto como para rendimento ajustado, rendeu mais massa de queijo que os demais tratamentos, porém as diferenças entre os três tipos de queijos não foram significativas $(\mathrm{P}>0,05)$.

Em controvérsia, Politis e Ng-Kwai-Hang (1988b) observaram que o incremento na CCS de 100.000 para 500.000 céls/mL foi associado com decréscimo de aproximadamente 
5\% no rendimento ajustado do queijo Cheddar, entretanto ao incrementar a CCS para 1.000.000 céls./mL houve um decréscimo superior, de 8,7\% no rendimento ajustado.

Os resultados do presente trabalho apresentaram-se inversos aos também encontrados por Grandinson (1986) e Mitchell et al., (1986b), podendo estarem relacionados ao fato do leite com altos níveis de CCS ter sido obtido de diferentes rebanhos com fornecimento de alimentação distinta, acarretando em maiores níveis de sólidos totais.

Outros fatores importantes que podem estar relacionados são: o elevado teor de umidade do queijo Minas (BEHMER, 1999) e também o teor de gordura. De acordo com Siqueira et al. (1986) o teor de gordura do leite tem um importante efeito no rendimento e na composição do queijo Minas Padrão, verificado pela correlação significativa e positiva entre a gordura e o rendimento do queijo. Porém, apesar dessa importância, a gordura do leite, sozinha, não pode explicar todas as variações de rendimento e composição dos queijos.

Furtado, Souza e Munck (1980) ao fabricar queijo Minas Frescal com e sem adição de cultura lática verificaram que o queijo produzido com exclusão de cultura lática apresentou menor acidificação, maior retenção de água e em conseqüência maior rendimento, porém estes resultados não explicam o maior rendimento do queijo de alta CCS, que ocorreu devido a maior concentração de sólidos, como citado anteriormente.

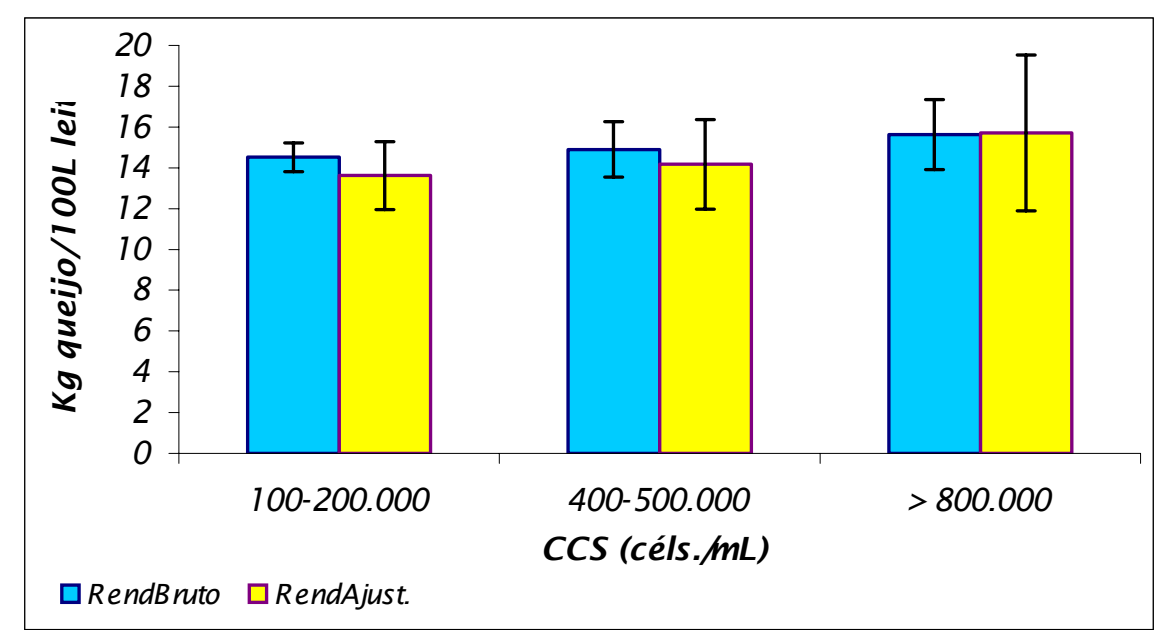

Figura 18. Rendimento bruto e ajustado dos queijos, de acordo com os níveis de células somáticas. A: 100.000-200.000 céls./mL; B: 400.000-500.000 céls./mL; C: > 800.000 céls./mL). 


\subsection{Queijo tipo Mussarela}

\subsubsection{Leite In Natura}

A Tabela 12 apresenta os resultados médios das análises físico-químicas efetuadas no leite cru utilizado na fabricação dos três lotes (repetições) do queijo tipo Mussarela. Pode-se observar que os valores se encontram dentro da faixa de normalidade (BRASIL, 2002), sendo que houve diferença significativa $(\mathrm{P}<0,05)$ entre os tipos de leite utilizados na fabricação, verificando que a gordura apresentou valores maiores para o leite contendo mais de 800.000 céls./mL, enquanto a proteína apresentou diferenças entre o leite de baixa (100.000-200.000 céls./mL) e alta CCS. As demais características estudadas não apresentaram efeito significativo $(\mathrm{P}>0,05)$ para CCS.

Como pode ser observado, o leite que contém maior CCS apresentou diferença numérica nas características avaliadas entre os demais leites. O mesmo foi verificado por outros autores, porém de forma inversa, sendo que para Politis e Ng-Kwai-Hang (1988a) o incremento de 100.000 para acima de 1.000 .000 céls/mL resultou em um queijo Cheddar contendo menos gordura (6,8\%), proteína (3,6\%), sólidos totais $(4,9 \%)$ e gordura na base seca (1,5\%), e $2 \%$ mais de proteína na base seca. Resultados semelhantes foram relatados por Schallibaum (2001). 
Tabela 12. Valores de densidade, acidez, pH e índice crioscópico (IC), gordura, proteína, lactose, sólidos totais (ST) e sólidos não gordurosos (SNG) do leite cru, utilizado na fabricação de queijo tipo Mussarela, de acordo com a contagem de células somáticas (CCS)1.

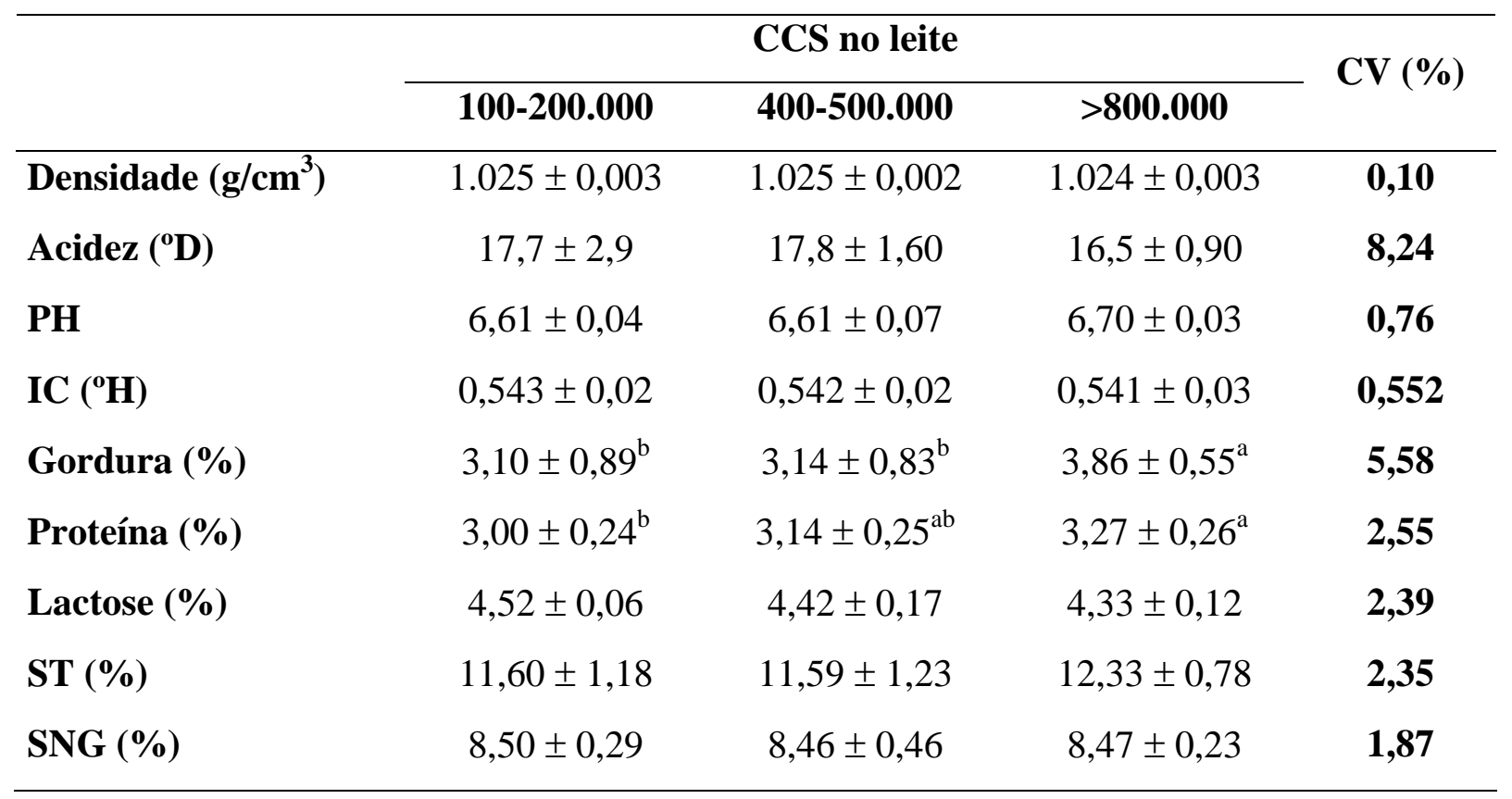

1 Resultados relativos à média \pm desvio padrão de três repetições (processamentos) de queijo, analisadas em duplicata.

Na linha, médias seguidas de letras minúsculas diferentes diferem entre si pelo teste de Tukey a $5 \%$.

Os resultados microbiológicos do leite cru utilizado na fabricação do queijo tipo Mussarela são apresentados na Tabela 13. Os valores médios de mesófilos, psicrotróficos e coliformes não sofreram efeito significativo $(\mathrm{P}>0,05)$ para CCS dos leites. Os resultados permitiram a utilização dos leites para os processamentos, por estarem dentro do que preconiza a legislação (BRASIL, 2001). A contagem de mesófilos e psicrotróficos foram sempre superiores no leite do mais de 800.00 céls./mL, apresentando 6,71 e 5,09 log ufc/mL, respectivamente. O leite com CCS de 400.000-500.000 céls/mL apresentou menor valor para estas características sendo, 5,39 e 3,22 log ufc/mL, respectivamente. 
Tabela 13. Análise microbiológica do leite cru, utilizado na fabricação de queijo tipo Mussarela, de acordo com a contagem de células somáticas (CCS)1.

\begin{tabular}{|c|c|c|c|c|}
\hline CCS no leite & $\begin{array}{c}\text { Mesófilos } \\
(\log \text { UFC/mL) }\end{array}$ & $\begin{array}{l}\text { Psicrotróficos } \\
\text { (log UFC/mL) }\end{array}$ & $\begin{array}{c}\text { Coliformes } 30^{\circ} \mathrm{C} \\
(\mathrm{NMP} / \mathrm{mL})\end{array}$ & $\begin{array}{c}\text { Coliformes } 45^{\circ} \mathrm{C} \\
(\mathrm{NMP} / \mathrm{mL})\end{array}$ \\
\hline $100-200.000$ & $5,91 \pm 1,06$ & $3,41 \pm 3,08$ & $2,04 \pm 0,00$ & $1,28 \pm 0,71$ \\
\hline $400-500.000$ & $5,39 \pm 1,85$ & $3,22 \pm 2,89$ & $2,04 \pm 0,00$ & $1,10 \pm 0,81$ \\
\hline$>800.000$ & $6,71 \pm 0,80$ & $5,09 \pm 0,37$ & $2,04 \pm 0,00$ & $1,23 \pm 0,89$ \\
\hline CV (\%) & 10,34 & 39,95 & $\mathbf{0}$ & 35,68 \\
\hline
\end{tabular}

${ }^{1}$ Resultados relativos à média \pm desvio padrão de três repetições (processamentos) de queijo, analisadas em duplicata.

Não foram observadas diferenças significativas pelo teste de Tukey a 5\%.

\subsubsection{Leite Pasteurizado}

As análises de $\mathrm{pH}$, acidez e microbiologia do leite pasteurizado, durante a fabricação do queijo tipo Mussarela, encontram-se nas Tabelas 14 e 15. Não houve diferenças significativas $(\mathrm{P}>0,05)$ em parâmetro algum analisado, sendo que todos os valores encontrados situaram-se dentro dos intervalos preconizados pela Agência de Vigilância Sanitária (BRASIL, 2001), considerado leite próprio para fabricação de queijos. Todas as amostras dos lotes apresentaram resultados negativos para fosfatase alcalina, e positivos para peroxidase, comprovando através destas enzimas a eficiência do tratamento térmico empregado na elaboração dos queijos.

Tabela 14. Valores de acidez e pH do leite pasteurizado, utilizado na fabricação de queijo tipo Mussarela, de acordo com a contagem de células somáticas (CCS)1.

\begin{tabular}{ccc}
\hline CCS no leite & Acidez ( $\left.{ }^{\mathbf{D}} \mathbf{D}\right)$ & $\mathbf{p H}$ \\
\hline $\mathbf{1 0 0}-\mathbf{2 0 0 . 0 0 0}$ & $17,5 \pm 0,08$ & $6,55 \pm 2,60$ \\
$\mathbf{4 0 0}-\mathbf{5 0 0 . 0 0 0}$ & $17,3 \pm 0,08$ & $6,56 \pm 2,53$ \\
$>\mathbf{8 0 0 . 0 0 0}$ & $16,3 \pm 0,08$ & $6,65 \pm 1,15$ \\
\hline $\mathbf{C V ~ ( \% )}$ & $\mathbf{6 , 6 3}$ & $\mathbf{1 , 3 6}$ \\
\hline
\end{tabular}

\footnotetext{
${ }^{1}$ Resultados relativos à média \pm desvio padrão de três repetições (processamentos) de queijo, analisadas em duplicata.

Não foram observadas diferenças significativas pelo teste de Tukey a 5\%.
} 
Os valores médios de coliformes totais $\left(30^{\circ} \mathrm{C}\right)$ variaram de 0,11 a 0,20 log $\mathrm{NMP} / \mathrm{mL}$, apresentando ausência no leite de CCS superior a 800.000 céls./mL. Enquanto houve ausência de coliformes fecais $\left(45^{\circ} \mathrm{C}\right)$ em todos os leites.

Tabela 15. Análise microbiológica do leite pasteurizado, utilizado na fabricação de queijo tipo Mussarela, de acordo com a contagem de células somáticas (CCS) 1.

\begin{tabular}{|c|c|c|c|c|}
\hline CCS no leite & $\begin{array}{c}\text { Mesófilos } \\
\text { (LogUFC/mL) }\end{array}$ & $\begin{array}{l}\text { Psicrotróficos } \\
\text { (LogUFC/mL) }\end{array}$ & $\begin{array}{c}\text { Coliformes } 30^{\circ} \mathrm{C} \\
(\operatorname{LogNMP} / \mathrm{mL})\end{array}$ & $\begin{array}{c}\text { Coliformes } 45^{\circ} \mathrm{C} \\
(\text { LogNMP/mL) }\end{array}$ \\
\hline $100-200.000$ & $1,50 \pm 1,46$ & Ausente & $0,11 \pm 0,19$ & Ausente \\
\hline $400-500.000$ & $2,03 \pm 0,39$ & Ausente & $0,20 \pm 0,38$ & Ausente \\
\hline$>800.000$ & $0,53 \pm 0,92$ & Ausente & Ausente & Ausente \\
\hline CV (\%) & 52,36 & - & 263,67 & - \\
\hline
\end{tabular}

${ }^{1}$ Resultados relativos à média \pm desvio padrão de três repetições (processamentos) de queijo, analisadas em duplicata.

Não foram observadas diferenças significativas pelo teste de Tukey a 5\%.

\subsubsection{Soro}

A Tabela 16 mostra os resultados das análises do soro obtido dos três processamentos realizados. Os resultados não apresentaram diferenças significativas, mas notou-se que houve maior porcentagem de gordura no tratamento acima de 800.000 células somáticas, conforme também observado por Barbano; Rasmussen; Lynch (1991).

Tabela 16. Percentuais de gordura, umidade, sólidos totais (ST) e sólidos não gordurosos (SNG) do soro, resultante da fabricação de queijo tipo Mussarela, de acordo com a contagem de células somáticas (CCS)1.

\begin{tabular}{cccc}
\hline CCS no leite & Gordura (\%) & ST (\%) & SNG (\%) \\
\hline $\mathbf{1 0 0}-\mathbf{2 0 0 . 0 0 0}$ & $0,58 \pm 0,06$ & $6,80 \pm 0,33$ & $6,22 \pm 0,40$ \\
$\mathbf{4 0 0}-\mathbf{5 0 0 . 0 0 0}$ & $0,50 \pm 0,10$ & $6,73 \pm 0,22$ & $6,23 \pm 0,37$ \\
$>\mathbf{8 0 0 . 0 0 0}$ & $0,65 \pm 0,28$ & $6,87 \pm 0,10$ & $6,22 \pm 0,45$ \\
\hline $\mathbf{C V ~ ( \% )}$ & $\mathbf{2 7 , 7 8}$ & $\mathbf{1 , 3 9}$ & $\mathbf{0 , 8 8}$ \\
\hline
\end{tabular}

\footnotetext{
${ }^{1}$ Resultados relativos à média \pm desvio padrão de três repetições (processamentos) de queijo, analisadas em duplicata.

Não foram observadas diferenças significativas pelo teste de Tukey a 5\%.
} 
As perdas de gordura, em porcentagem, para os tratamentos 100.000-200.000 céls./mL, 400.000-500.000 céls./mL e >800.000 céls./mL foram respectivamente 18,71, 15,92 e 16,84\%, apresentando perda média de 17,2\%, considerada acima da média nacional de 10 a 15\% (O RENDIMENTO..., 2005).

Esta perda de gordura através do soro se dá em função da temperatura de pasteurização do leite, teor de cálcio e proteínas, acidez, pH e temperatura de adição do coalho, que afeta a coagulação do leite. Além destes há outros fatores como, a rapidez do corte, o tamanho dos grãos e a intensidade da agitação feita imediatamente após o corte, possuem forte influência nas perdas de gordura e proteínas do soro. (O RENDIMENTO..., 2005).

\subsubsection{Queijo Tipo Mussarela}

A Tabela 17 mostra que os resultados microbiológicos do queijo tipo Mussarela apresentaram-se dentro dos valores estabelecidos pela legislação brasileira. Não houve efeito de interação entre a CCS e dias de armazenamento, para nenhuma das características avaliadas, porém somente na contagem de pscicrotróficos houve efeito significativo $(\mathrm{P}<0,05)$ para dias de armazenamento (Figura 19).

Os níveis de mesófilos foram semelhantes entre os tratamentos e durante tempo de estocagem, variando de 6,55 a 7,21 log ufc/mL no alta CCS e 6,76 a 6,80 no média CCS, indicando um bom desenvolvimento do cultivo lácteo empregado na fabricação deste queijo. Os níveis de psicrotróficos tiveram crescimento gradual até o $23^{\circ}$ dia de análise, porém no dia 30 ocorreu um decréscimo de aproximadamente uma fase log em todos os queijos. Os resultados estão de acordo com a legislação vigente (BRASIL, 1980), sendo classificado como queijo de massa filada de consistência firme.

A contaminação microbiana em queijos possui destacada relevância no meio industrial porque que pode causar alterações organolépticas e risco de veiculação de agentes de toxiinfecções alimentares (OLIVEIRA et al., 1998). Dentre os agentes contaminantes as bactérias do grupo coliforme são as principais associadas à deterioração dos queijos, causando fermentações anormais e estufamento precoce do produto.

Neste experimento não foram contatados níveis detectáveis de coliformes fecais (45 ${ }^{\circ} \mathrm{C}$ ) nos três tipos de queijos, porém os coliformes totais variaram de 0 a $0,19 \log$ ufc/mL nos queijos com CCS de 100.000-200.000 céls./mL, de 0 a 0,77 log ufc/mL nos queijos com CCS de 400.000-500.000 céls./mL, e de 0 a 1,01 log ufc/mL nos queijos com CCS superior a 
800.000 céls./mL, verificando a qualidade inferior do queijo fabricado com leite de alta CCS, como destacado por Schällibaum (2001).

Os valores de coliformes totais e fecais estão de acordo com a legislação brasileira, porém nesta não constam limites de tolerância para coliformes totais em queijos, que segundo Lück (1987) é um fator preocupante, pois se presentes no queijo tipo Mussarela revelam condições de higiene insuficientes dos equipamentos e utensílios utilizados na fabricação dos queijos, ou ainda problemas na pasteurização.

Tabela 17. Análise microbiológica do queijo tipo Mussarela, de acordo com a contagem de células somáticas (CCS)1.

\begin{tabular}{cccccc}
\hline \multicolumn{5}{c}{ Mesófilos (logUFC/g) } \\
\hline CCS no leite & Dia 2 & Dia 9 & Dia 16 & Dia 23 & Dia 30 \\
\hline $\mathbf{1 0 0 - \mathbf { 2 0 0 . 0 0 0 }}$ & $6,76 \pm 0,34$ & $6,45 \pm 0,61$ & $6,64 \pm 0,85$ & $6,76 \pm 0,82$ & $6,66 \pm 0,65$ \\
$\mathbf{4 0 0}-\mathbf{5 0 0 . 0 0 0}$ & $6,76 \pm 0,08$ & $6,36 \pm 0,59$ & $6,33 \pm 0,55$ & $6,95 \pm 0,70$ & $6,80 \pm 1,07$ \\
$>\mathbf{8 0 0 . 0 0 0}$ & $6,55 \pm 0,11$ & $6,80 \pm 0,90$ & $6,30 \pm 0,23$ & $6,48 \pm 0,71$ & $7,21 \pm 0,72$ \\
\hline CV (\%) & & $\mathbf{8 , 1 4}$ & & \\
\hline Regressão & & ns &
\end{tabular}

Psicrotróficos (logUFC/g)*

\begin{tabular}{cccccc}
\hline CCS no leite & Dia 2 & Dia 9 & Dia 16 & Dia 23 & Dia 30 \\
\hline $\mathbf{1 0 0 - \mathbf { 2 0 0 . 0 0 0 }}$ & $0,00 \pm 0,00$ & $3,03 \pm 2,79$ & $3,88 \pm 3,47$ & $5,89 \pm 0,68$ & $4,71 \pm 1,11$ \\
$\mathbf{4 0 0 - 5 0 0 . 0 0 0}$ & $0,00 \pm 0,00$ & $4,06 \pm 3,53$ & $4,26 \pm 3,72$ & $6,57 \pm 1,13$ & $5,43 \pm 0,97$ \\
$>\mathbf{8 0 0 . 0 0 0}$ & $0,00 \pm 0,00$ & $3,51 \pm 3,27$ & $5,89 \pm 1,62$ & $6,26 \pm 0,71$ & $5,51 \pm 1,60$ \\
\hline CV (\%) & & $\mathbf{6 9 , 2 3}$ & & \\
\hline
\end{tabular}

\section{Regressão}

Quadrática

${ }^{1}$ Resultados relativos à média \pm desvio padrão de três repetições (processamentos), analisadas em duplicata nos dias 2, 9, 16, 23 e 30 após a fabricação.

* Médias de características significativas $(\mathrm{P}<0,05)$ segundo análise de regressão

A Figura 19 mostra um efeito quadrático dos dias de armazenamento sobre a quantidade de psicrotróficos, sendo que houve aumento na quantidade de psicrotróficos até o $21^{\circ}$ dia de armazenamento e a partir do vértice dessa parábola, ponto de máxima, começa a ocorrer à diminuição de psicrotróficos à medida que aumenta os dias de armazenamento. 


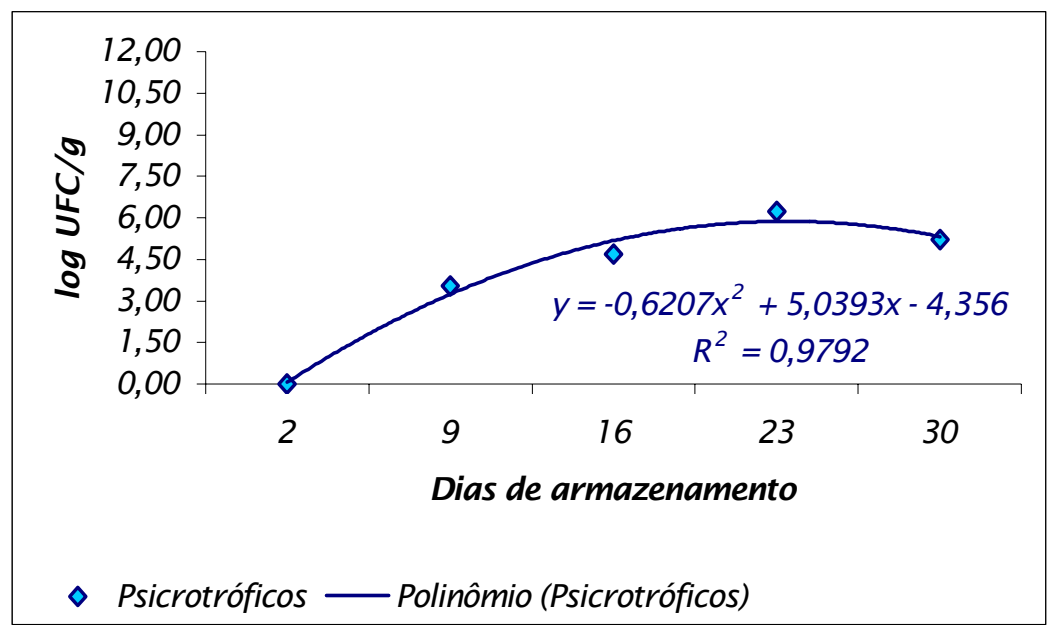

Figura 19. Evolução da contagem de psicrotróficos em função dos dias de armazenamento.

A Tabela 18 apresenta os resultados das análises físico-químicas do queijo tipo Mussarela nos dias 2, 9, 16, 23 e 30 após a fabricação. Os valores das características encontram-se dentro da composição média do queijo Mussarela no Brasil (FURTADO; LOURENÇO NETO, 1994).

Não houve interação significativa $(\mathrm{P}>0,05)$ entre CCS e dias de armazenamento para qualquer parâmetro físico-químico avaliado, porém houve efeito significativo $(\mathrm{P}<0,05)$ dos dias de armazenamento para $\mathrm{pH}$, apresentando efeito linear positivo $(\mathrm{Y}=0,017 \mathrm{x}+5,543$; $\mathrm{R}^{2}=0,4882$ ), sendo que para cada aumento de um dia de armazenamento o $\mathrm{pH}$ do queijo aumenta em 0,017.

Pizaia et al (2003), ao estudar queijos Mussarela obtido por método tradicional e ultrafiltração, observaram que houve uma diminuição do $\mathrm{pH}$ no primeiro mês de estocagem, em função da degradação da lactose residual e que após este período houve aumento de pH decorrente da liberação de aminoácidos básicos decorrentes da proteólise secundária.

Os resultados abaixo diferem dos encontrados por Politis; NG-Kwai-Hang (1988a) os quais mostraram que níveis altos (600.000 céls/mL) de CCS afetam o conteúdo de gordura, proteína, sólidos totais e sólidos não gordurosos. 
Tabela 18. Valores de pH, acidez, percentuais de gordura na base seca (GBS), proteína total (PT), matéria seca (MS) e óleo livre do queijo tipo Mussarela, de acordo com a contagem de células somáticas (CCS) no leite cru ${ }^{1}$.

\begin{tabular}{cccccc}
\hline & \multicolumn{5}{c}{ pH $^{*}$} \\
\hline CCS no leite & Dia 2 & Dia 9 & Dia 16 & Dia 23 & Dia 30 \\
\hline $\mathbf{1 0 0 - \mathbf { 2 0 0 . 0 0 0 }}$ & $5,52 \pm 0,12$ & $5,56 \pm 0,15$ & $5,60 \pm 0,08$ & $5,53 \pm 0,08$ & $5,57 \pm 0,10$ \\
$\mathbf{4 0 0 - \mathbf { 5 0 0 . 0 0 0 }}$ & $5,56 \pm 0,09$ & $5,61 \pm 0,09$ & $5,68 \pm 0,06$ & $5,64 \pm 0,06$ & $5,62 \pm 0,13$ \\
$>\mathbf{8 0 0 . 0 0 0}$ & $5,53 \pm 0,11$ & $5,57 \pm 0,11$ & $5,66 \pm 0,07$ & $5,60 \pm 0,10$ & $5,67 \pm 0,02$ \\
\hline CV (\%) & & $\mathbf{1 , 7 2}$ & \\
\hline Regressão & & Linear
\end{tabular}

\section{Acidez $\left({ }^{\circ} \mathrm{D}\right)$}

\begin{tabular}{cccccc}
\hline CCS no leite & Dia 2 & Dia 9 & Dia 16 & Dia 23 & Dia 30 \\
\hline $\mathbf{1 0 0 - \mathbf { 2 0 0 . 0 0 0 }}$ & $15,00 \pm 2,65$ & $14,17 \pm 1,53$ & $13,83 \pm 1,04$ & $14,50 \pm 1,80$ & $14,33 \pm 1,76$ \\
$\mathbf{4 0 0 - \mathbf { 5 0 0 . 0 0 0 }}$ & $14,50 \pm 3,91$ & $13,50 \pm 3,91$ & $14,17 \pm 4,25$ & $14,83 \pm 3,62$ & $16,00 \pm 2,50$ \\
$>\mathbf{8 0 0 . 0 0 0}$ & $14,00 \pm 2,60$ & $14,17 \pm 3,33$ & $13,50 \pm 2,78$ & $13,83 \pm 2,75$ & $14,00 \pm 3,00$ \\
\hline CV (\%) & & $\mathbf{2 0 , 3 5}$ & & \\
\hline Regressão & & ns &
\end{tabular}

\begin{tabular}{cccccc}
\hline \multicolumn{6}{c}{ GBS (\%) } \\
\hline CCS no leite & Dia 2 & Dia 9 & Dia 16 & Dia 23 & Dia 30 \\
\hline $\mathbf{1 0 0 - \mathbf { 2 0 0 . 0 0 0 }}$ & $51,52 \pm 7,91$ & $53,62 \pm 7,26$ & $50,34 \pm 9,77$ & $53,21 \pm 8,61$ & $54,96 \pm 9,83$ \\
$\mathbf{4 0 0 - 5 0 0 . 0 0 0}$ & $52,08 \pm 5,57$ & $50,10 \pm 1,64$ & $48,97 \pm 3,95$ & $48,88 \pm 3,23$ & $52,32 \pm 9,09$ \\
$>\mathbf{8 0 0 . 0 0 0}$ & $52,62 \pm 2,97$ & $53,40 \pm 7,61$ & $49,88 \pm 12,13$ & $50,84 \pm 7,72$ & $50,76 \pm 7,15$ \\
\hline CV (\%) & & $\mathbf{1 4 , 5 8}$ & &
\end{tabular}

\begin{tabular}{cccccc}
\hline \multicolumn{7}{c}{ Regressão } & \multicolumn{5}{c}{ ns } \\
\hline \multicolumn{7}{c}{ PT (\%) } \\
\hline CCS no leite & Dia 2 & Dia 9 & Dia 16 & Dia 23 & Dia 30 \\
\hline $\mathbf{1 0 0 - \mathbf { 2 0 0 . 0 0 0 }}$ & $22,32 \pm 3,14$ & $22,13 \pm 3,58$ & $20,87 \pm 2,68$ & $20,31 \pm 1,19$ & $20,24 \pm 2,17$ \\
$\mathbf{4 0 0 - 5 0 0 . 0 0 0}$ & $20,92 \pm 2,79$ & $22,29 \pm 3,23$ & $20,95 \pm 2,57$ & $20,33 \pm 2,12$ & $19,36 \pm 1,83$ \\
$>\mathbf{8 0 0 . 0 0 0}$ & $19,38 \pm 1,05$ & $21,56 \pm 4,29$ & $20,44 \pm 2,47$ & $20,38 \pm 2,09$ & $16,69 \pm 4,34$ \\
\hline CV (\%) & & $\mathbf{1 3 , 1 2}$ & & \\
\hline Regressão & & $\mathbf{5}$ & \\
\hline
\end{tabular}


Tabela 18. Valores de $\mathrm{pH}$, acidez, percentuais de gordura na base seca (GBS), proteína total (PT), matéria seca (MS) e óleo livre do queijo tipo Mussarela, de acordo com a contagem de células somáticas (CCS) no leite $\mathrm{cru}^{1}$ (Continuação).

MS (\%)

\begin{tabular}{cccccc}
\hline CCS no leite & Dia 2 & Dia 9 & Dia 16 & Dia 23 & Dia 30 \\
\hline $\mathbf{1 0 0 - \mathbf { 2 0 0 . 0 0 0 }}$ & $50,79 \pm 1,46$ & $51,67 \pm 2,75$ & $49,39 \pm 3,54$ & $49,80 \pm 3,34$ & $48,91 \pm 3,45$ \\
$\mathbf{4 0 0 - \mathbf { 5 0 0 . 0 0 0 }}$ & $50,29 \pm 0,70$ & $51,53 \pm 1,23$ & $49,92 \pm 4,59$ & $50,90 \pm 2,15$ & $50,26 \pm 1,40$ \\
$>\mathbf{8 0 0 . 0 0 0}$ & $50,93 \pm 3,06$ & $51,46 \pm 3,53$ & $50,20 \pm 3,58$ & $50,46 \pm 3,20$ & $50,04 \pm 1,50$ \\
\hline CV (\%) & & $\mathbf{5 , 6 6}$ & & \\
\hline Regressão & & ns & & \\
\hline
\end{tabular}

\begin{tabular}{cccccc}
\hline \multicolumn{5}{c}{ Cinzas (\%) } \\
\hline CCS no leite & Dia 2 & Dia 9 & Dia 16 & Dia 23 & Dia 30 \\
\hline $\mathbf{1 0 0 - \mathbf { 2 0 0 . 0 0 0 }}$ & $4,51 \pm 1,88$ & $3,39 \pm 1,15$ & $3,56 \pm 0,27$ & $3,73 \pm 0,50$ & $3,48 \pm 0,56$ \\
$\mathbf{4 0 0 - \mathbf { 5 0 0 . 0 0 0 }}$ & $4,55 \pm 2,10$ & $3,39 \pm 1,00$ & $3,72 \pm 0,99$ & $3,60 \pm 0,07$ & $3,19 \pm 0,60$ \\
$>\mathbf{8 0 0 . 0 0 0}$ & $3,86 \pm 1,33$ & $3,81 \pm 1,54$ & $3,38 \pm 0,69$ & $3,87 \pm 0,68$ & $3,88 \pm 0,86$ \\
\hline CV (\%) & & $\mathbf{2 9 , 4 2}$ &
\end{tabular}

\begin{tabular}{cccccc}
\hline \multicolumn{7}{c}{ Regressão } & \multicolumn{5}{c}{ Óleo livre (\%) } \\
\hline CCS no leite & Dia 2 & Dia 9 & Dia 16 & Dia 23 & Dia 30 \\
\hline $\mathbf{1 0 0 - \mathbf { 2 0 0 . 0 0 0 }}$ & $2,54 \pm 0,87$ & $2,99 \pm 1,05$ & $3,54 \pm 0,40$ & $2,67 \pm 0,34$ & $2,73 \pm 0,68$ \\
$\mathbf{4 0 0 - \mathbf { 5 0 0 . 0 0 0 }}$ & $3,13 \pm 0,28$ & $2,88 \pm 0,82$ & $2,83 \pm 0,14$ & $3,56 \pm 0,41$ & $3,25 \pm 0,91$ \\
$>\mathbf{8 0 0 . 0 0 0}$ & $3,39 \pm 0,55$ & $3,84 \pm 0,28$ & $3,09 \pm 1,06$ & $3,23 \pm 0,62$ & $3,49 \pm 0,48$ \\
\hline $\mathbf{C V ~ ( \% ) ~}$ & & $\mathbf{2 0 , 9 1}$ &
\end{tabular}

\section{Regressão}

ns

${ }^{1}$ Resultados relativos à média \pm desvio padrão de três repetições (processamentos), analisadas em duplicata nos dias 2, 9, 16, 23 e 30 após a fabricação.

* Médias de características significativas $(\mathrm{P}<0,05)$ segundo análise de regressão

A porcentagem gordura na base seca, proteína total, matéria seca, cinzas, óleo livre e acidez não foram influenciadas pelos fatores CCS, dias de armazenamento e pela sua interação. Para a porcentagem de óleo livre verificou-se que o queijo de alta CCS apresentou valores superiores nos dias 2, 16 e 30 de armazenamento. O mesmo ocorreu para os teores de gordura, exceto no dia 30. De acordo com Rowney et al (2003), estudando a fabricação de queijo Mussarela com leite homogeneizado, não homogeneizado e misturado 1:1, verificaram que à medida que decresceu o tamanho do glóbulo de gordura decresceu a formação de óleo 
livre, porém não se sabe ao certo qual a causa dessa diminuição na formação de óleo livre. Estes autores verificaram que o leite não homogeneizado apresentou 9\% de óleo livre, enquanto o misturado e o homogeneizado apresentaram 5,5 e 2,7\%, respectivamente.

Os resultados referentes às concentrações de AGL do queijo tipo Mussarela são apresentados na Tabela 19. Houve interação significativa $(\mathrm{P}<0,05)$ entre CCS e dias de armazenamento (Figura 20). Para esta característica observou-se que em todos os níveis houve um aumento na concentração de AGL no decorrer do período de armazenamento. Pode-se observar que as concentrações de AGL do queijo de alta CCS apresentaram-se sempre superiores aos demais (Figura 20).

Estes resultados sugerem que as altas concentrações de AGL estão associadas às quantidades de células somáticas do leite utilizado na fabricação. Esta afirmação está de acordo com outros autores de que o leite com alta CCS possui maior concentração inicial de AGL (Murphy et al., 1989; RANDOLPH; ERWIN, 1974).

Porém de acordo com Prata (1998) os ácidos graxos livres (AGL) são obtidos da gordura do leite pela ação catalítica de lipases normalmente presentes no leite, sendo assim, os valores de AGL do presente experimento também são explicados, pois o leite de alta CCS possui maior teor de gordura que os leites de baixa e média CCS.

Tabela 19. Concentrações de ácidos graxos livres (AGL) do queijo tipo Mussarela, de acordo com a contagem de células somáticas (CCS) do leite $\mathrm{cru}^{1}$.

\begin{tabular}{cccccc}
\hline \multirow{2}{*}{ CCS no leite } & \multicolumn{5}{c}{ Concentração de AGL (meq/L) ( $^{*}$} \\
\cline { 2 - 6 } & Dia 2 & Dia 9 & Dia 16 & Dia 23 & Dia 30 \\
\hline $\mathbf{1 0 0 - \mathbf { 2 0 0 . 0 0 0 }}$ & $2,27 \pm 0,32$ & $1,99 \pm 0,28$ & $2,41 \pm 0,38$ & $2,11 \pm 0,51$ & $2,34 \pm 1,02$ \\
$\mathbf{4 0 0 - \mathbf { 5 0 0 . 0 0 0 }}$ & $2,27 \pm 0,62$ & $1,97 \pm 0,49$ & $2,19 \pm 0,04$ & $2,47 \pm 0,61$ & $2,65 \pm 0,70$ \\
$>\mathbf{8 0 0 . 0 0 0}$ & $2,99 \pm 0,47$ & $3,17 \pm 0,51$ & $2,64 \pm 0,39$ & $3,11 \pm 0,65$ & $3,29 \pm 0,66$ \\
\hline
\end{tabular}

CV (\%)

Regressão

${ }^{1}$ Resultados relativos à média \pm desvio padrão de três repetições (processamentos), analisadas em duplicata nos dias 2, 9, 16, 23 e 30 após a fabricação.

${ }^{2}$ Expresso em ácido palmítico.

* Médias de características significativas $(\mathrm{P}<0,05)$ segundo análise de regressão 


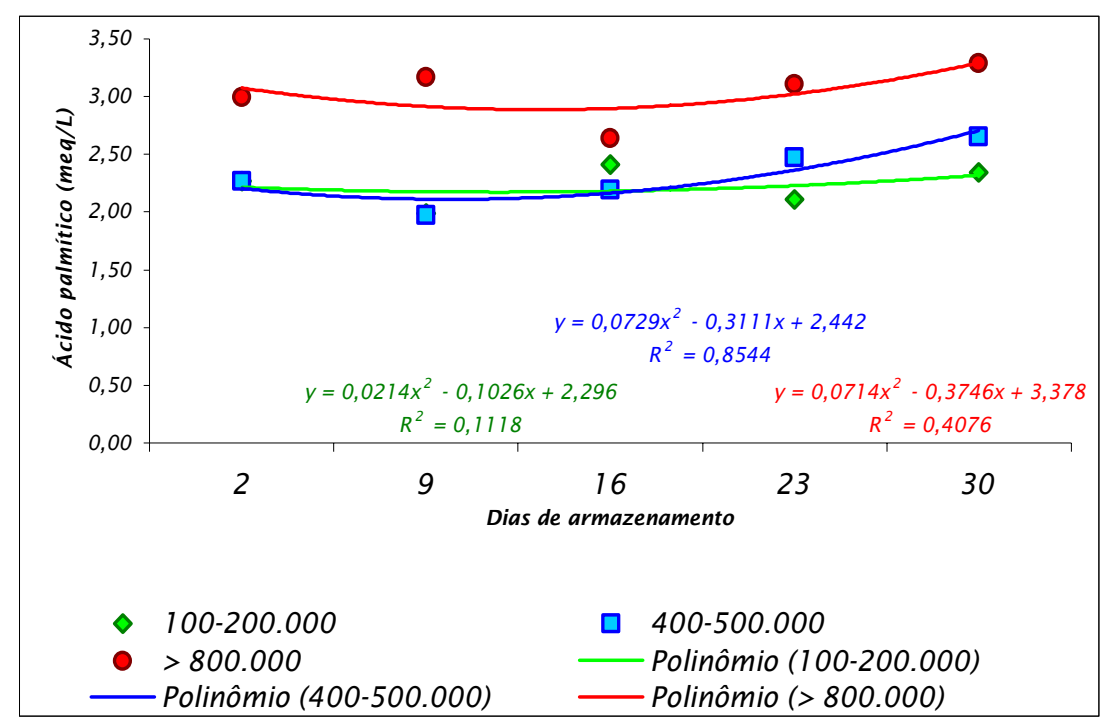

Figura 20. Evolução da concentração de AGL dos queijos tipo Mussarela em função dos dias de armazenamento.

Os resultados de proteólise, extensão e profundidade da proteólise do queijo Mussarela estão apresentados na Tabela 20. Os índices não sofreram interação entre CCS e dias de armazenamento, nem efeito significativo da CCS, porém para todos houve efeito linear $(p<0,05)$ em relação aos dias de armazenamento (Figuras 21 e 22). Estes resultados sugerem que a proteólise nos queijos Mussarela é decorrente do desenvolvimento do cultivo lácteo empregado, de enzimas naturais do leite e do poder do coagulante utilizado, sendo que o nível de CCS parece ter pouca contribuição para este evento durante o armazenamento por 30 dias.

Tabela 20. Índices de proteólise, profundidade e extensão da proteólise do queijo tipo Mussarela ${ }^{1}$, de acordo com a contagem de células somáticas (CCS) no leite cru.

\section{Proteólise $^{*}$}

\begin{tabular}{cccccc}
\hline CCS no leite & Dia 2 & Dia 9 & Dia 16 & Dia 23 & Dia 30 \\
\hline $\mathbf{1 0 0 - \mathbf { 2 0 0 . 0 0 0 }}$ & $1,01 \pm 0,05$ & $0,99 \pm 0,01$ & $0,97 \pm 0,04$ & $0,94 \pm 0,02$ & $0,95 \pm 0,04$ \\
$\mathbf{4 0 0 - 5 0 0 . 0 0 0}$ & $0,99 \pm 0,01$ & $0,97 \pm 0,02$ & $0,95 \pm 0,01$ & $0,92 \pm 0,01$ & $0,91 \pm 0,01$ \\
$>\mathbf{8 0 0 . 0 0 0}$ & $0,96 \pm 0,02$ & $0,95 \pm 0,03$ & $0,93 \pm 0,03$ & $0,93 \pm 0,02$ & $0,91 \pm 0,07$ \\
\hline CV (\%) & & & $\mathbf{3 , 2 4}$ & &
\end{tabular}


Tabela 20. Índices de proteólise, profundidade e extensão da proteólise do queijo tipo Mussarela ${ }^{1}$, de acordo com a contagem de células somáticas (CCS) no leite cru.

\begin{tabular}{cccccc}
\hline \multicolumn{5}{c}{ Profundidade da Proteólise $^{*}$} \\
CCS no leite & Dia 2 & Dia 9 & Dia 16 & Dia 23 & Dia 30 \\
\hline $\mathbf{1 0 0 - \mathbf { 2 0 0 . 0 0 0 }}$ & $6,14 \pm 1,53$ & $5,26 \pm 0,80$ & $5,95 \pm 0,64$ & $5,02 \pm 0,45$ & $6,98 \pm 1,31$ \\
$\mathbf{4 0 0 - \mathbf { 5 0 0 . 0 0 0 }}$ & $5,13 \pm 1,53$ & $4,79 \pm 0,80$ & $4,12 \pm 0,64$ & $5,32 \pm 0,45$ & $5,82 \pm 1,31$ \\
$>\mathbf{8 0 0 . 0 0 0}$ & $3,99 \pm 0,88$ & $5,03 \pm 0,34$ & $4,60 \pm 0,19$ & $5,57 \pm 0,30$ & $6,72 \pm 2,09$ \\
\hline CV (\%) & & $\mathbf{3 6 , 9 2}$ & \\
\hline Regressão & & Linear & \\
\hline
\end{tabular}

\section{Extensão da Proteólise*}

\begin{tabular}{cccccc}
\hline CCS no leite & Dia 2 & Dia 9 & Dia 16 & Dia 23 & Dia 30 \\
\hline $\mathbf{1 0 0 - \mathbf { 2 0 0 . 0 0 0 }}$ & $5,69 \pm 2,30$ & $6,58 \pm 2,92$ & $8,56 \pm 5,05$ & $10,54 \pm 2,53$ & $11,48 \pm 3,38$ \\
$\mathbf{4 0 0 - \mathbf { 5 0 0 . 0 0 0 }}$ & $6,66 \pm 1,69$ & $8,00 \pm 3,69$ & $8,79 \pm 0,93$ & $12,76 \pm 2,26$ & $14,10 \pm 1,53$ \\
$>\mathbf{8 0 0 . 0 0 0}$ & $7,59 \pm 1,38$ & $9,48 \pm 2,20$ & $10,87 \pm 3,17$ & $12,55 \pm 2,09$ & $15,40 \pm 7,90$ \\
\hline $\mathbf{C V ~ ( \% )}$ & & & $\mathbf{3 3 , 4 4}$ & & \\
\hline
\end{tabular}

\section{Regressão}

\section{Linear}

${ }^{1}$ Resultados relativos à média \pm desvio padrão de três (repetições) processamentos, analisadas em duplicata nos dias 2, 9, 16, 23 e 30 após a fabricação.

* Médias de características significativas $(\mathrm{P}<0,05)$ segundo análise de regressão

Verificou-se que os índices de proteólise diminuíram ao longo do período de estocagem nos três queijos analisados. O queijo de CCS acima de 800.000 céls/mL apresentou o menor índice ao logo de todo o período, variando de 0,96 a 0,91\%, seguido do queijo de média (400.000-500.000 céls/mL) CCS e do queijo com CCS entre 100.000 e 200.000 céls./mL, o qual apresentou variação de 1,01 a 0,95\%. Assim, o índice de proteólise apresentou efeito linear negativo, sendo que para cada aumento de um dia no armazenamento a proteólise do queijo diminui $0,16 \%$. Estes resultados concordam com os resultados obtidos por Haenlein et al. (1973), Ballou et al (1975) e Schultz (1977).

Entretanto, Marino et al. (2005) encontraram resultados contrários aos apresentados neste experimento, ao estudar no queijo Cheddar, o efeito das enzimas proteolíticas das células somáticas, adicionadas ao leite, sobre a qualidade do queijo. Estes verificaram que a proteólise, durante o maturação do queijo, aumentou com a adição de células somáticas 
(300.000 céls./mL e 600.000 céls./mL), embora tenha apresentado efeito reduzido devido há pasteurização do leite após a adição das células somáticas.

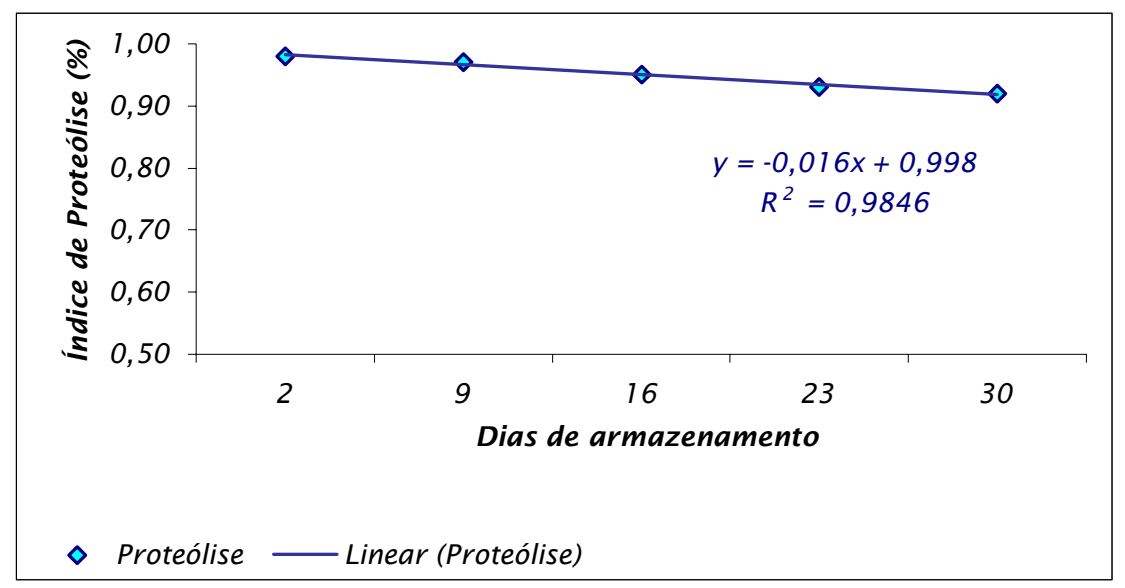

Figura 21. Evolução do índice da proteólise dos queijos tipo Mussarela em função dos dias de armazenamento.

Os índices de profundidade e extensão da proteólise tiveram crescimento linear ao longo do período de estocagem, sendo que para cada aumento de um dia no armazenamento a extensão e profundidade da proteólise aumenta 1,795 e 0,311\%, respectivamente.

Os índices de profundidade da proteólise do queijo produzido com leite de baixa CCS variaram de 6,14 a 6,98\%, enquanto no queijo CCS acima de 800.000 céls./mL os índices tiveram variação de 3,99 a 6,92\%, já o índice de extensão da profundidade deste mesmo queijo variou de 7,59 a 15,40\%.

Comportamento semelhante dos índices foi encontrado por Narimatsu et al (2003) e Pizaia et al. (2003) ao trabalharem com queijo Mussarela obtido pelos métodos tradicional e ultrafiltração, verificando que a extensão e profundidade aumentaram ao longo do tempo, entretanto os índices de proteólise do queijo fabricado pelo método tradicional foi maior que os demais, justificado pela menor quantidade de soroproteínas, que tendem a limitar fisicamente o acesso das enzimas proteolíticas às caseínas ao se ligarem à superfície das mesmas. 


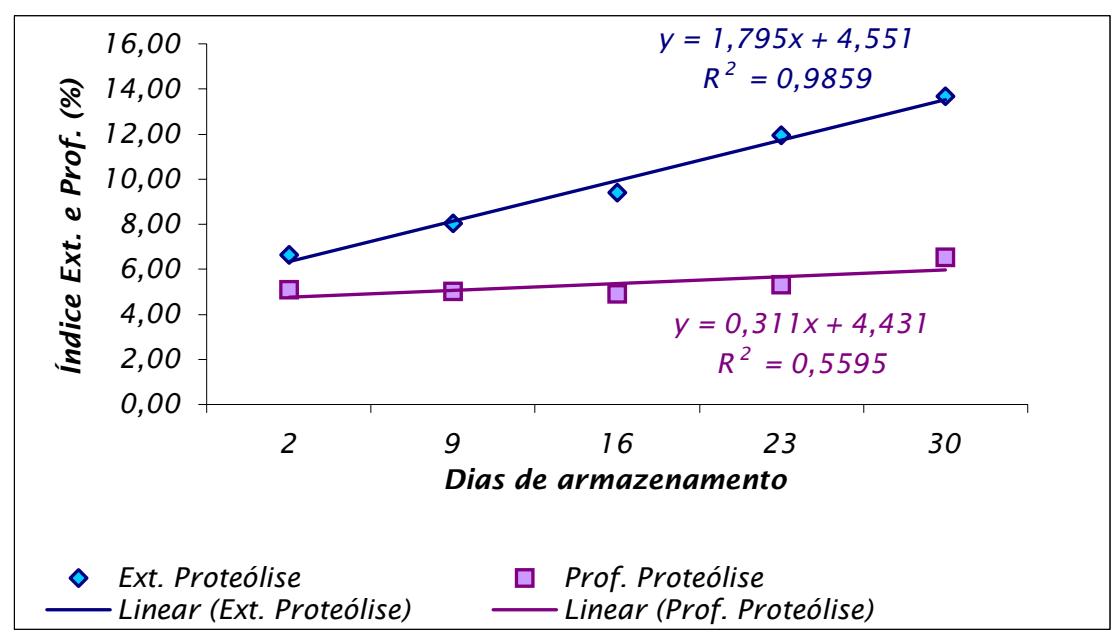

Figura 22. Evolução dos índices de extensão e profundidade da proteólise dos queijos tipo Mussarela em função dos dias de armazenamento.

Na Tabela 21 são apresentados os percentuais da capacidade de derretimento do queijo tipo Mussarela. Verificou-se que houve interação $(\mathrm{P}<0,05)$ entre CCS e dias de armazenamento, para esta característica (Figura 23).

O gráfico de capacidade de derretimento em função dos dias de armazenamento (Figura 23) mostra que o queijo, no início do armazenamento, possui certa dificuldade em derreter, mas no decorrer do tempo a capacidade de derretimento da Mussarela aumenta em todos os queijos, também observado em pesquisas realizadas por Kindsted (1993).

Este fato, segundo Oliveira (1986), ocorre porque na fase inicial as proteínas apresentam alto peso molecular, tornando-as pouco solúveis, e após duas a três semanas essas proteínas são hidrolisadas, ficando mais solúveis o que vai aumentando a capacidade de derretimento da Mussarela, até a mesma apresentar-se excessiva e tornar o queijo impróprio para uso no preparo de pizzas (KINDSTED, 1993).

Comportamento diferente foi obtido por Pizaia et al. (2003), ao avaliar queijo Mussarela obtido pelos métodos tradicional e ultrafiltração, pois verificaram que a capacidade de derretimento da Mussarela padrão foi constante até cerca de 30 dias de estocagem, tendendo depois a diminuir. 
Tabela 21. Percentuais da capacidade de derretimento do queijo tipo Mussarela, de acordo com a contagem de células somáticas (CCS) do leite $\mathrm{cru}^{1}$.

\section{Capacidade de Derretimento*}

\begin{tabular}{cccccc}
\hline CCS no leite & Dia 2 & Dia 9 & Dia 16 & Dia 23 & Dia 30 \\
\hline $\mathbf{1 0 0 - \mathbf { 2 0 0 . 0 0 0 }}$ & $17,09 \pm 3,60$ & $23,88 \pm 0,43$ & $27,06 \pm 2,44$ & $30,06 \pm 7,34$ & $33,83 \pm 3,39$ \\
$\mathbf{4 0 0 - \mathbf { 5 0 0 . 0 0 0 }}$ & $18,89 \pm 3,23$ & $27,40 \pm 2,42$ & $38,61 \pm 8,88$ & $49,79 \pm 8,88$ & $48,57 \pm 3,11$ \\
$>\mathbf{8 0 0 . 0 0 0}$ & $19,39 \pm 3,58$ & $39,06 \pm 4,86$ & $68,10 \pm 33,00$ & $74,65 \pm 11,02$ & $61,72 \pm 6,48$ \\
\hline CV (\%) & & & $\mathbf{2 6 , 4 3}$ & &
\end{tabular}

\section{Regressão}

Quadrática

${ }^{1}$ Resultados relativos à média \pm desvio padrão de três repetições (processamentos), analisadas em duplicata nos dias 2, 9, 16, 23 e 30 após a fabricação.

* Médias de características significativas $(\mathrm{P}<0,05)$ segundo análise de regressão

A Figura 23 mostra um efeito quadrático dos dias de armazenamento sobre a capacidade de derretimento, os queijos de baixa e média CCS apresentaram menor capacidade de derretimento que o queijo de alta CCS. Tal comportamento foi devido à menor porcentagem de gordura destes queijos, pois segundo Furtado (1997) o menor teor de gordura, juntamente com um aumento do $\mathrm{pH}$, entre outras características, interfere negativamente sobre a capacidade de derretimento do queijo tipo Mussarela.

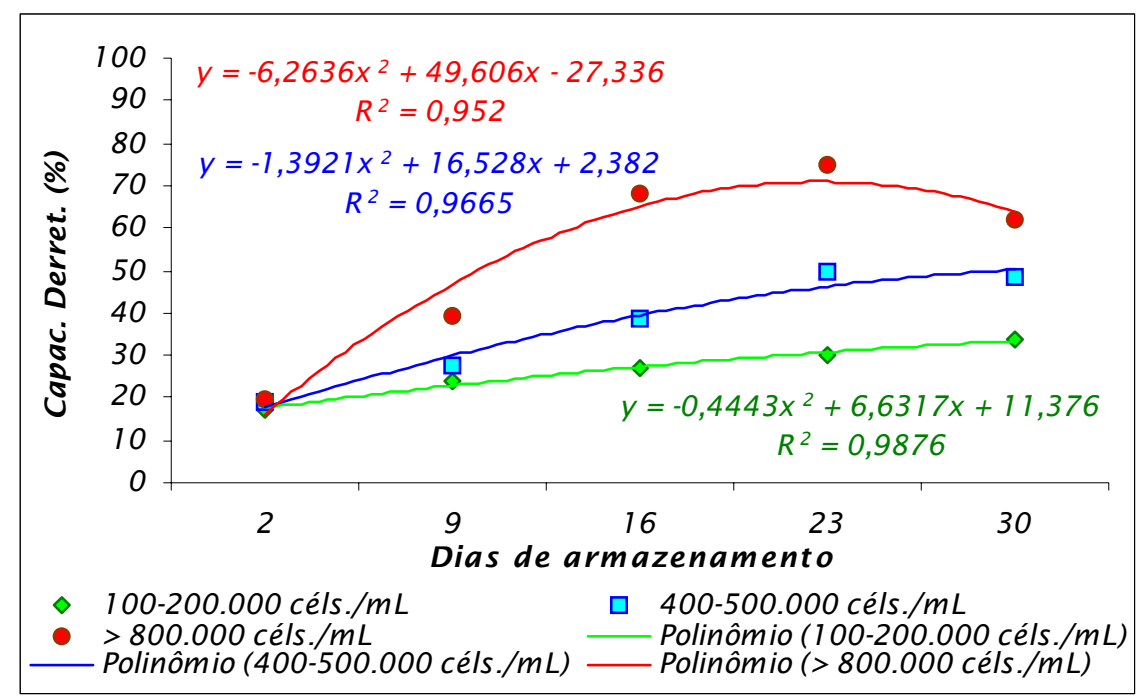

Figura 23. Avaliação da capacidade de derretimento durante o armazenamento. (») A: 100200.000 céls./mL; $(\square)$ B: 400-500.000 céls./mL; (o) C: > 800.000 céls./mL. 
A capacidade de derretimento também diferiu entre os níveis de CS, utilizados para fabricação dos queijos, sendo que os queijos com alta CCS apresentaram maior capacidade de derretimento que os demais. Esta propriedade funcional do queijo Mussarela é particularmente importante na confecção de alimentos prontos para consumo imediatamente após aquecimento, como pizzas e lasanhas, nos quais o queijo Mussarela é utilizado como ingrediente de cobertura. Deste modo, uma alta capacidade de derretimento, observada nos queijos com alta CCS, pode determinar uma maior fluidez do queijo derretido e, portanto, uma perda das características de espalhamento do queijo no produto, causando uma menor aceitação por parte do consumidor.

As características de firmeza, elasticidade e mastigabilidade encontram-se expostos na Tabela 22.

Tabela 22. Valores de firmeza, elasticidade e mastigabilidade do queijo tipo Mussarela, de acordo com a contagem de células somáticas (CCS) no leite cru ${ }^{1}$.

\begin{tabular}{|c|c|c|c|c|c|}
\hline \multicolumn{6}{|c|}{ Firmeza (g) } \\
\hline CCS no leite & Dia 2 & Dia 9 & Dia 16 & Dia 23 & Dia 30 \\
\hline 100-200.000 & $5528 \pm 3155$ & $5224 \pm 2064$ & $4182 \pm 1700$ & $3986 \pm 285$ & $3924 \pm 176$ \\
\hline $400-500.000$ & $5451 \pm 3171$ & $4351 \pm 924$ & $4122 \pm 1669$ & $4660 \pm 521$ & $4064 \pm 672$ \\
\hline$>800.000$ & $4440 \pm 1622$ & $4828 \pm 2631$ & $4227 \pm 1405$ & $4639 \pm 251$ & $4029 \pm 1463$ \\
\hline CV (\%) & \multicolumn{5}{|c|}{24,84} \\
\hline Regressão & \multicolumn{5}{|c|}{ ns } \\
\hline \multicolumn{6}{|c|}{ Elasticidade $^{*}$} \\
\hline CCS no leite & Dia 2 & Dia 9 & Dia 16 & Dia 23 & Dia 30 \\
\hline 100-200.000 & $0,90 \pm 0,01$ & $0,83 \pm 0,08$ & $0,80 \pm 0,15$ & $0,82 \pm 0,16$ & $0,78 \pm 0,09$ \\
\hline $400-500.000$ & $0,88 \pm 0,06$ & $0,78 \pm 0,07$ & $0,78 \pm 0,01$ & $0,71 \pm 0,08$ & $0,71 \pm 0,04$ \\
\hline$>800.000$ & $0,88 \pm 0,01$ & $0,83 \pm 0,12$ & $0,73 \pm 0,07$ & $0,74 \pm 0,07$ & $0,73 \pm 0,06$ \\
\hline CV (\%) & \multicolumn{5}{|c|}{8,60} \\
\hline Regressão & \multicolumn{5}{|c|}{ Linear } \\
\hline
\end{tabular}

Continua... 
Tabela 22. Valores de firmeza, elasticidade e mastigabilidade do queijo tipo Mussarela, de acordo com a contagem de células somáticas (CCS) no leite cru

\begin{tabular}{|c|c|c|c|c|c|}
\hline \multicolumn{6}{|c|}{ Mastigabilidade $^{*}$} \\
\hline CCS no leite & Dia 2 & Dia 9 & Dia 16 & Dia 23 & Dia 30 \\
\hline 100-200.000 & $2907 \pm 1641$ & $2581 \pm 1216$ & $1892 \pm 715$ & $2040 \pm 674$ & $1875 \pm 580$ \\
\hline $400-500.000$ & $3069 \pm 2043$ & $2083 \pm 781$ & $1854 \pm 822$ & $2098 \pm 677$ & $1666 \pm 460$ \\
\hline$>800.000$ & $2228 \pm 894$ & $2066 \pm 1350$ & $1798 \pm 796$ & $2075 \pm 570$ & $1653 \pm 690$ \\
\hline CV (\%) & & & 31,31 & & \\
\hline Regressão & & & Linear & & \\
\hline
\end{tabular}

Não houve interação $(\mathrm{P}>0,05)$ entre CCS e dias de armazenamento para todas as características estudadas, bem com não houve efeito significativo ( $\mathrm{P}>0,05)$ para CCS. Porém, para elasticidade e mastigabilidade houve efeito linear negativo para dias de armazenamento (Figura 24), sendo que, para cada aumento de um dia de armazenamento tem-se uma diminuição de 0,036 e de 217,97 nos resultados de elasticidade e mastigabilidade do queijo, respectivamente.

Estes resultados concordam com os obtidos por Valle et al. (2004) que ao analisar diferentes teores de gordura nas análises funcionais verificaram que à medida que o teor de gordura aumenta, diminui a firmeza, elasticidade e a mastigabilidade. Segundo Imm et al (2003) quando os teores de gordura e proteína são similares, a extensão da proteólise pode ser responsável pelas diferenças texturais em queijos, pois a extensão da proteólise, como já citada anteriormente está fundamentalmente relacionada com as proteinases naturais do leite, que degradam a proteína em peptídeos de alto peso molecular, como observado na extensão da proteólise (Figura 22) deste experimento. 


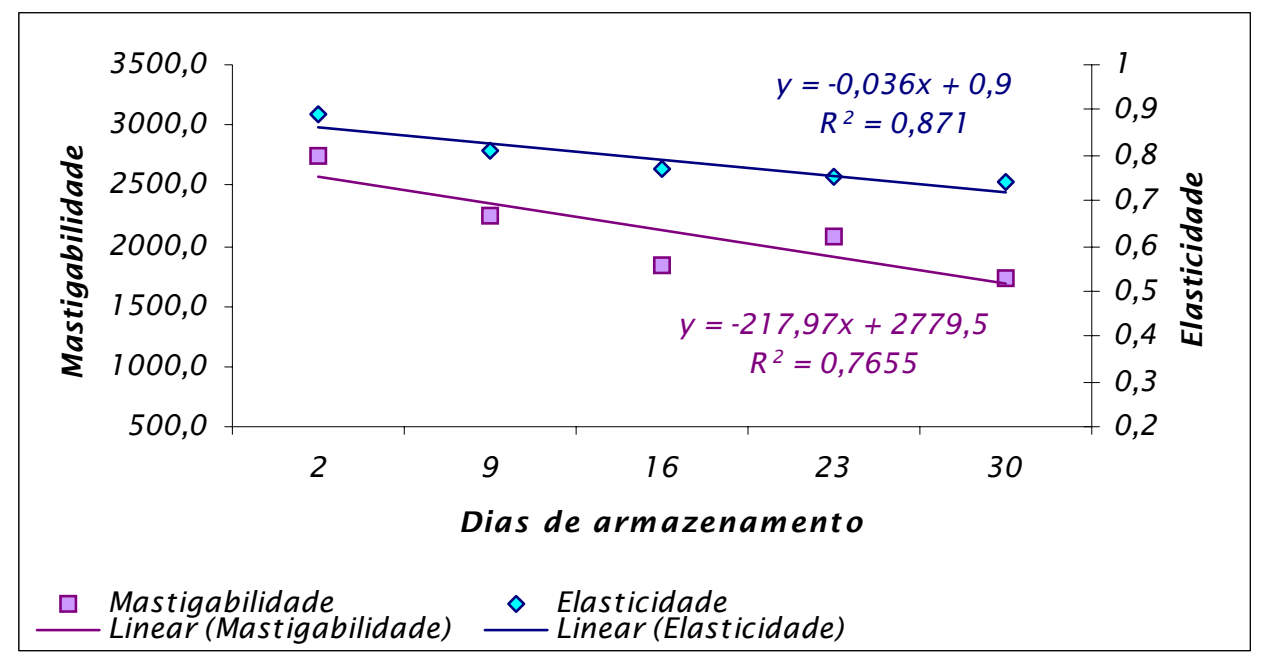

Figura 24. Valores de elasticidade e mastigabilidade dos queijos tipo Mussarela em função dos dias de armazenamento.

A Tabela 23 apresenta os resultados obtidos na análise sensorial do queijo tipo Mussarela nos dias 2, 9, 16, 23 e 30. Os atributos avaliados foram: textura, sabor, aroma, aparência e nota final de aceitação do produto. O aroma, sabor, textura e aceitação global não foram influenciados $(\mathrm{P}>0,05)$ pelo tipo de leite utilizado na fabricação e pelo tempo de armazenamento do queijo.

A aparência diferiu estatisticamente entre os queijos de diferentes níveis de células nos dias 2, 16 e 30 após a fabricação. O queijo obtido com alta CCS recebeu nota superior aos demais níveis no dia 2, ocorrendo inversão do resultado nos dias 16 e 30. Os resultados indicam que a utilização de leite contendo CCS acima de 800.000 céls./mL determinou pequenas alterações sensoriais no queijo tipo Mussarela, segundo os avaliadores. Provavelmente devido à presença de altas contagens de microrganismos mesófilos durante o armazenamento (Tabela 17), proporcionadas, sobretudo pelo desenvolvimento do cultivo lácteo, tenha contribuído para minimizar os efeitos negativos da elevada CCS no queijo tipo Mussarela.

Resultados significativamente diferentes, para o atributo aparência, também foram verificados por Verruma-Bernardi e Damásio (2004), ao estudar queijo Mozarela de leite de búfala através de análise descritiva de perfil livre. Estes verificaram que o queijo Mozarela elaborado pelo método tradicional apresentou cor mais branca, maior firmeza e fibrosidade enquanto o elaborado pela acidificação direta, apresentou-se mais macio, com maior umidade e coloração esverdeada. 
Tabela 23. Valores de aroma, sabor, textura, aparência e aceitação global do queijo tipo Mussarela, de acordo com a contagem de células somáticas (CCS) ${ }^{1}$.

\section{Aroma}

\begin{tabular}{cccccc}
\hline CCS no leite & Dia 2 & Dia 9 & Dia 16 & Dia 23 & Dia 30 \\
\hline $\mathbf{1 0 0 - \mathbf { 2 0 0 . 0 0 0 }}$ & $5,00 \pm 1,31^{\mathrm{a}}$ & $6,00 \pm 1,53^{\mathrm{a}}$ & $6,00 \pm 1,43^{\mathrm{a}}$ & $6,50 \pm 1,30^{\mathrm{a}}$ & $7,00 \pm 1,41^{\mathrm{a}}$ \\
$\mathbf{4 0 0 - \mathbf { 5 0 0 . 0 0 0 }}$ & $6,00 \pm 1,33^{\mathrm{a}}$ & $6,00 \pm 1,56^{\mathrm{a}}$ & $6,00 \pm 1,49^{\mathrm{a}}$ & $7,00 \pm 1,22^{\mathrm{a}}$ & $7,00 \pm 1,37^{\mathrm{a}}$ \\
$>\mathbf{8 0 0 . 0 0 0}$ & $6,00 \pm 1,57^{\mathrm{a}}$ & $7,00 \pm 1,57^{\mathrm{a}}$ & $7,00 \pm 1,53^{\mathrm{a}}$ & $7,00 \pm 1,35^{\mathrm{a}}$ & $7,00 \pm 1,48^{\mathrm{a}}$ \\
\hline $\mathbf{C V ~ ( \% )}$ & & & $\mathbf{2 2 , 0 6}$ & & \\
\hline
\end{tabular}

\section{Sabor}

\begin{tabular}{cccccc}
\hline CCS no leite & Dia 2 & Dia 9 & Dia 16 & Dia 23 & Dia 30 \\
\hline $\mathbf{1 0 0 - \mathbf { 2 0 0 . 0 0 0 }}$ & $7,00 \pm 1,92^{\mathrm{a}}$ & $6,00 \pm 2,02^{\mathrm{a}}$ & $7,00 \pm 1,47^{\mathrm{a}}$ & $7,00 \pm 1,69^{\mathrm{a}}$ & $8,00 \pm 1,86^{\mathrm{a}}$ \\
$\mathbf{4 0 0 - \mathbf { 5 0 0 . 0 0 0 }}$ & $6,00 \pm 2,07^{\mathrm{a}}$ & $7,00 \pm 2,04^{\mathrm{a}}$ & $7,00 \pm 1,93^{\mathrm{a}}$ & $7,00 \pm 1,52^{\mathrm{a}}$ & $7,00 \pm 1,39^{\mathrm{a}}$ \\
$>\mathbf{8 0 0 . 0 0 0}$ & $5,00 \pm 2,28^{\mathrm{a}}$ & $7,00 \pm 2,17^{\mathrm{a}}$ & $7,00 \pm 2,04^{\mathrm{a}}$ & $7,00 \pm 1,86^{\mathrm{a}}$ & $8,00 \pm 1,62^{\mathrm{a}}$ \\
\hline $\mathbf{C V ~ ( \% )}$ & & & $\mathbf{2 8 , 5 4}$ & & \\
\hline
\end{tabular}

\section{Textura}

\begin{tabular}{cccccc}
\hline CCS no leite & Dia 2 & Dia 9 & Dia 16 & Dia 23 & Dia 30 \\
\hline $\mathbf{1 0 0 - \mathbf { 2 0 0 . 0 0 0 }}$ & $6,00 \pm 1,93^{\mathrm{a}}$ & $7,00 \pm 1,81^{\mathrm{a}}$ & $7,00 \pm 1,62^{\mathrm{a}}$ & $7,00 \pm 1,70^{\mathrm{a}}$ & $7,00 \pm 1,49^{\mathrm{a}}$ \\
$\mathbf{4 0 0 - \mathbf { 5 0 0 . 0 0 0 }}$ & $6,00 \pm 1,77^{\mathrm{a}}$ & $7,00 \pm 1,48^{\mathrm{a}}$ & $8,00 \pm 1,85^{\mathrm{a}}$ & $7,00 \pm 1,52^{\mathrm{a}}$ & $8,00 \pm 1,49^{\mathrm{a}}$ \\
$>\mathbf{8 0 0 . 0 0 0}$ & $6,00 \pm 2,00^{\mathrm{a}}$ & $7,00 \pm 1,58^{\mathrm{a}}$ & $7,00 \pm 1,88^{\mathrm{a}}$ & $8,00 \pm 2,21^{\mathrm{a}}$ & $7,00 \pm 1,60^{\mathrm{a}}$ \\
\hline $\mathbf{C V ~ ( \% )}$ & & $\mathbf{2 5 , 8 8}$ & & \\
\hline
\end{tabular}

\section{Aparência}

\begin{tabular}{cccccc}
\hline CCS no leite & Dia 2 & Dia 9 & Dia 16 & Dia 23 & Dia 30 \\
\hline $\mathbf{1 0 0 - \mathbf { 2 0 0 . 0 0 0 }}$ & $6,00 \pm 1,91^{\mathrm{b}}$ & $7,00 \pm 1,63^{\mathrm{a}}$ & $8,00 \pm 1,67^{\mathrm{a}}$ & $7,00 \pm 1,84^{\mathrm{a}}$ & $7,00 \pm 1,50^{\mathrm{b}}$ \\
$\mathbf{4 0 0 - \mathbf { 5 0 0 . 0 0 0 }}$ & $6,00 \pm 2,01^{\mathrm{b}}$ & $7,00 \pm 1,67^{\mathrm{a}}$ & $8,00 \pm 1,29^{\mathrm{a}}$ & $8,00 \pm 1,56^{\mathrm{a}}$ & $8,00 \pm 1,19^{\mathrm{a}}$ \\
$>\mathbf{8 0 0 . 0 0 0}$ & $8,00 \pm 1,55^{\mathrm{a}}$ & $7,00 \pm 1,91^{\mathrm{a}}$ & $6,00 \pm 1,96^{\mathrm{b}}$ & $7,00 \pm 1,38^{\mathrm{a}}$ & $6,00 \pm 1,93^{\mathrm{c}}$ \\
\hline $\mathbf{C V ~ ( \% )}$ & & & $\mathbf{2 6 , 5 6}$ & & \\
\hline
\end{tabular}

\section{Aceitação Global}

\begin{tabular}{cccccc}
\hline CCS no leite & Dia 2 & Dia 9 & Dia 16 & Dia 23 & Dia 30 \\
\hline $\mathbf{1 0 0 - \mathbf { 2 0 0 . 0 0 0 }}$ & $6,00 \pm 1,83^{\mathrm{a}}$ & $7,00 \pm 1,46^{\mathrm{a}}$ & $7,00 \pm 1,51^{\mathrm{a}}$ & $7,00 \pm 1,65^{\mathrm{a}}$ & $7,00 \pm 1,27^{\mathrm{a}}$ \\
$\mathbf{4 0 0 - \mathbf { 5 0 0 . 0 0 0 }}$ & $6,00 \pm 1,88^{\mathrm{a}}$ & $7,00 \pm 1,63^{\mathrm{a}}$ & $7,00 \pm 1,67^{\mathrm{a}}$ & $7,00 \pm 1,38^{\mathrm{a}}$ & $7,00 \pm 1,38^{\mathrm{a}}$ \\
$>\mathbf{8 0 0 . 0 0 0}$ & $6,00 \pm 1,76^{\mathrm{a}}$ & $7,00 \pm 1,62^{\mathrm{a}}$ & $7,00 \pm 6,71^{\mathrm{a}}$ & $7,00 \pm 1,74^{\mathrm{a}}$ & $7,00 \pm 1,55^{\mathrm{a}}$ \\
\hline $\mathbf{C V ~ ( \% )}$ & & & $\mathbf{2 4 , 1 6}$ & & \\
\hline
\end{tabular}

${ }^{1}$ Resultados relativos à mediana \pm desvio padrão.

a,b.c Médias seguidas de diferentes letras nas colunas diferem estatisticamente pelo teste de Dunn a 5\%. 
Valle at al. (2004) ao estudarem a influência do teor de gordura nas propriedades funcionais do queijo tipo Mozarela, verificaram que sensorialmente, por meio de análise descritiva quantitativa, apenas a firmeza e a resistência à mastigação mostraram diferenças significativas em função do teor de gordura, obtendo-se que o produto fabricado com $2 \%$ de gordura no leite é mais firme, e apresenta maior resistência à mastigação.

A Figura 25 apresenta os valores de rendimento bruto e ajustado do queijo tipo Mussarela fabricado com leites de diferentes níveis de células somáticas. As diferenças entre os três tipos de queijos não foram significativas $(\mathrm{P}>0,05)$, contrariamente ao observado por outros autores os quais observaram um menor rendimento na fabricação utilizando leite contendo > 500.000 céls./mL em queijo Minas Frescal (MATIOLI et al., 2000), em queijo Cheddar (GRANDINSON; FORD, 1986; BARBANO; RASMUSSEN; LYNCH, 1991) e queijo cottage estudado por Klei et al. (1998), os quais verificaram que o incremento na CCS de 83.000 céls./mL para 872.500 céls./mL influenciou o rendimento, onde a eficiência foi inferior para o coalho do queijo cottage fabricado de leite com alta CCS.

Deve-se ressaltar, porém, que o leite com alto nível de CCS, utilizado no presente estudo, apresentou maiores teores de sólidos totais, o que pode ter proporcionado a obtenção de maior massa de queijo (BEHMER, 1999). Outro fator importante para as diferenças encontradas no presente trabalho e em estudos anteriores seria a própria característica dos processamentos, sobretudo nas etapas de tratamento da massa, em relação aos queijos estudados (Minas frescal e Mussarela), portanto mais sensível a variações no rendimento.

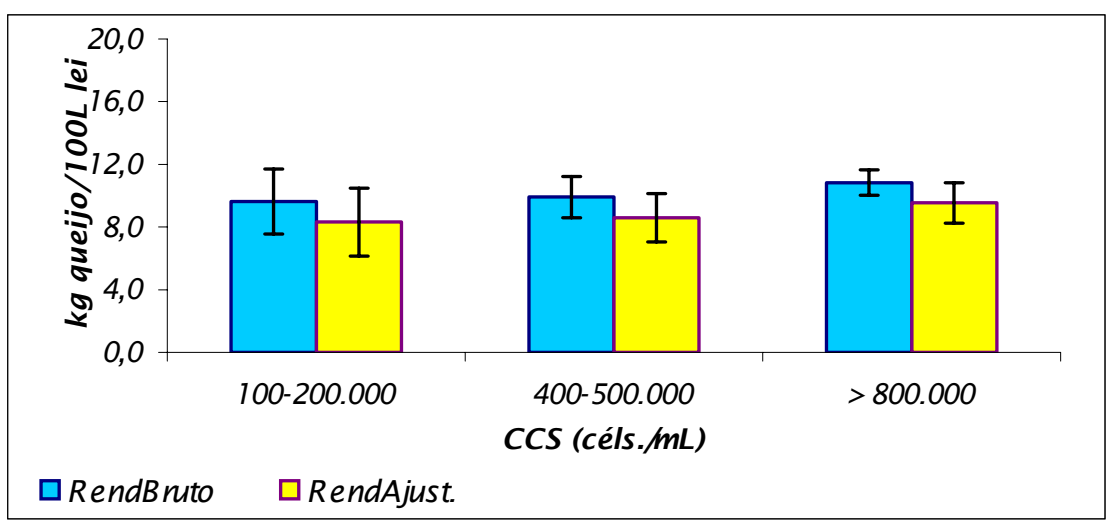

Figura 25. Rendimento bruto e ajustado do queijo tipo Mussarela produzido com diferentes níveis de CS. A: 100.000-200.000 céls./mL; B: 400.000-500.000 céls./mL e C: > 800.000 céls/mL. 


\section{CONCLUSÕES}

1. O queijo Minas frescal produzido com leite contendo níveis de CCS acima de 800.000 céls./mL apresenta decréscimo dos atributos sensoriais, com exceção da textura, no $30^{\circ}$ dia de armazenamento a $7^{\circ} \mathrm{C} ;$;

2. A acidez do queijo Minas contendo alta CCS aumenta a partir do $9^{\circ}$ dia de armazenamento;

3. As concentrações de AGL são maiores no queijo Minas produzido com maior CCS, porém, as diferenças entre as médias não são significativas ao longo do período de armazenamento;

4. As características microbiológicas (contagem de mesófilos e psicrotróficos), matéria seca, acidez e textura do queijo Minas variam significativamente durante o armazenamento por 30 dias;

5. Os demais parâmetros físico-químicos ( $\mathrm{pH}$, gordura, cinzas) e o rendimento de fabricação do queijo Minas não sofrem variações significativas $(P>0,05)$ associadas aos diferentes níveis de CCS utilizados no estudo;

6. A utilização de leite contendo CCS igual ou acima de 400-500.000 céls./mL determina somente um decréscimo na nota de aparência do queijo tipo Mussarela no $30^{\circ}$ dia de armazenamento. Entretanto, a CCS não produz nenhum outro efeito significativo na análise sensorial do produto;

7. O grau de lipólise é maior no queijo tipo Mussarela produzido com CCS acima de 800.000 céls./mL, observando-se diferenças significativas entre as concentrações médias de AGL a partir do $9^{\circ}$ dia de armazenamento;

8. A capacidade de derretimento é maior no queijo tipo Mussarela produzido com alta CCS, sendo que esta variável aumenta significativamente $(\mathrm{P}>0,05)$ a partir do $16^{\circ}$ dia de armazenamento; 
9. Para os parâmetros texturais (mastigabilidade e elasticidade), índice de proteólise, extensão e profundidade da proteólise, e contagem de psicrotróficos no qieijo Mussarela, há um efeito linear para dias de armazenamento;

10. Os demais parâmetros físico-químicos (pH, acidez, gordura, PT, MS, cinzas), óleo livre e o rendimento de fabricação do queijo tipo Mussarela não são afetados significativamente pelos níveis de CCS utilizados no estudo;

11. A perda de gordura através do soro é maior na fabricação do queijo tipo Mussarela produzido com CCS acima de 800.000 céls./mL, porém, as diferenças entre as médias não são significativas;

12. A avaliação global dos resultados obtidos no presente trabalho indica que o leite destinado à fabricação dos queijos Minas e tipo Mussarela deve apresentar CCS até 400-500.000 céls./mL, de maneira a evitar alterações na qualidade dos produtos ao longo do período de armazenagem. 


\section{REFERÊNCIAS BIBLIOGRÁFICAS}

ADAD, J.M.T. Indústria de alimentos de origem animal atividade básica da medicina veterinária ou da química? (Conclusão). Informativo CFQ. p.6-12, abril-jun., 2004.

ADDA, J.; GRIPON, J.C.; VASSAL, L. The chemistry of flavour and texture generation in cheese. Food Chemistry. v.9, p.115-129, 1982.

AGARWAL, W.K.; NARAYANAN, K.M. Influence of mastitis on the physico-chemical status of milk lipids. IV. Oxidative and hydrolytic properties. Journal of Dairy Science. v.32, p.84-86, 1979.

[APHA] AMERICAN PUBLIC HEALTH ASSOCIATION. Standard methods for the examination of dairy products. $16^{\text {th }}$ ed. Washington, APHA, 1992.

AMERINE, M.A.; PANGBORN, R.M.; ROESSLER, E.M. A principle of sensory evaluation of foods. 1967, New York: Academic Press, 1967.

ANDERSON, M. Source and significance of lysosomal enzymes in bovine milk fat globule membrane. Journal of Dairy Science. v.60, p.1217-1222, 1977.

ANDERSON, M.; ANDREWS, A.T. Progressive changes in individual milk protein concentrations associated with high somatic cell counts. Journal of Dairy Research. v.44, p.223-235, 1977.

ANDREWS, A. T.; OLIVERCRONA, T.; BENGTSSON-OLIVERCRONA, G.; FOX, P. F.; BJORCK, L.; FARKYE, N. Y. Indigenous enzymes in milk. Food Enzymology. v.1, p.53129, 1991.

ANUALPEC - ANUÁRIO DA PECUÁRIA BRASILEIRA. 2005. São Paulo: FNP Editora, 400p., 2005.

ARCURI, E.F. Influência de bactérias psicrotróficos na qualidade do leite e produtos lácteos. In: BRITO, J.R.F.; PORTUGAL, J.A.B. Diagnóstico da qualidade doleite, impacto para a indústria e a questão dos resíduos de antibióticos. Juiz de Fora: Embrapa Gado de Leite, 2003. Cap. 10, p.105-115. 
ARENALES, M.C. Mastite: sua importância econômica. Disponível em: $<$ http://www.bichoonline.com.br/artigos/Xmc0002.htm>. Acesso em: 01 novembro 2005.

[AOAC] ASSOCIATION OF OFFICIAL ANALYTICAL CHEMISTS, I. Official Methods of Analysis. $16^{\text {th }}$ ed. Arlington, VA. 1995.

AULDIST, M.J.; COATS, S.; ROGERS, G.L.; MCDOWELL, G.H. Changes in the compositional of milk from normal and mastitic dairy cows during the lactation cycle. Australian Journal of Experimental Agriculture. v.35, p.427-436, 1995.

AULDIST, M.J.; COATS, S.J.; SUTHERLAND, B.J.; HARDHAM, J.F.; MCDOWELL, G.H.; ROGERS, G.L. Effect of somatic cell count and stage of lactation on the quality and storage life of ultra high temperature milk. Journal of Dairy Research. v.63, p.377-386, 1996a.

AULDIST, M.J., COATS, S.J., SUTHERLAND, B.J., MAYES, J.J., MCDOWELL, G.H., ROGERS, G.L. Effect of somatic cell count and stage of lactation on raw milk composition and the yield and quality of cheddar cheese. Journal of Dairy Research. v.63, p.269-280, 1996b.

AULDIST, M.J.; HUBLLE, I.B. Effects of mastitis on raw milk and dairy products. Australian Journal of Dairy Technology. v.53, p.28-36, 1998.

BALLOU, L.U.; PASQUINI, M.; BREMEL, R.D.; EVERSON, T.; SOMER, D. Factors affecting herd milk composition and milk plasmin at four levels of somatic cell counts. Journal of Dairy Science. v.78, p.2186-2195, 1995.

BARBANO, D.M.; SHERBON, J.W. Cheddar cheese yields in New York. Journal of Dairy Science. v.67, p.1873-1883, 1984.

BARBANO, D.M.; RASMUSSEN, R.R.; LYNCH, J.M. Influence of milk somatic cell count and milk age on cheese yield. Journal of Dairy Science. v.74, p.369-388, 1991.

BARROS, C.M.V. Influência da cultura lática, lípase, salga e embalagem nas características físico-químicas e sensoriais do queijo Minas curado. 2001. Dissertação (Mestrado) - Faculdade de Farmácia, Universidade Federal de Minas Gerais, Belo Horizonte, 2001. 
BEHMER, M.L.A. Laticínios - Leite, manteiga, queijo, caseína e instalações. 2.ed., Melhoramentos: São Paulo, 1956.

BEHMER, M.L.A. Tecnologia do leite. 10.ed., Nobel: São Paulo, 95p., 1980.

BEHMER, M.L.A. Tecnologia do Leite. 13.ed. São Paulo: Nobel, 1999.

BRASIL. Ministério da Agricultura. Regulamento da Inspeção Industrial e Sanitária de Produtos de Origem Animal - R.I.I.S.P.O.A. Aprovado pelo decreto $\mathrm{n}^{\circ}$ 30690, de 20.03.52, alterado pelo decreto $\mathrm{n}^{0}$ 1255, de 25.06.52. Diário Oficial da União, Brasília, DF, 1980. 116p.

BRASIL. Ministério da Agricultura. Secretaria Nacional de Defesa Agropecuária. Laboratório Nacional de Referência Animal - LANARA. Métodos analíticos oficiais para controle de produtos de origem animal e seus ingredientes. Métodos físicos e químicos, 2. Brasília, DF, 1981.

BRASIL. Portaria no 146 (1), de 7 de março de 1996. Aprova o regulamento técnico de identidade e qualidade dos produtos lácteos - Regulamento Técnico de Identidade e Qualidade de Queijos. Diário Oficial da União, Brasília, DF, 7 mar. 1996.

BRASIL. Portaria $\mathrm{n}^{\circ}$ 352, de 4 de setembro de 1997. Aprova o regulamento técnico para fixação de identidade e qualidade de queijo Minas Frescal. Diário Oficial da União, Brasília, DF, 4 set. 1997a.

BRASIL. Portaria $\mathrm{n}^{\circ}$ 352, de 4 de setembro de 1997. Aprova o regulamento técnico para fixação de identidade e qualidade de queijo Mozzarella (Muzzarella ou Mussarela). Diário Oficial da União, Brasília, DF, 4 set. 1997b.

BRASIL. Ministério da Saúde, Agência Nacional de Vigilância Sanitária, Resolução ${ }^{\circ}{ }^{12}$, de 02 de janeiro de 2001. Aprova o regulamento técnico sobre padrões microbiológicos para alimentos. Diário Oficial da União, Brasília, DF, 02 jan. 2001. 51p.

BRASIL. Instrução Normativa $n^{0}$ 51, de 18 de setembro de 2002. Aprova os regulamentos técnicos de produção, identidade e qualidade do leite tipo A, do leite tipo B, do leite tipo C, do leite pasteurizado e do leite cru refrigerado e o regulamento técnico da coleta de leite cru refrigerado e seu transporte a granel. Diário Oficial da União, Brasília, DF, 18 set. 2002. Seção 1, n.183, p.13-22. 
BRUS, D.H.J.; JAARTSVELD, F.H.J. Comparison of batches of spray-dried milk power prepared from milks with milks with a low and a high cell count. Milk Dairy Journal. v.25, p.221-223, 1971.

CAFFIN, J.P.; POUTREL, B.; RAINARD, P. Physiological and pathological factors influencing bovine alfa-lactoalbumin and beta-lactoglobulin concentration in milk. Journal of Dairy Science. v.68, p.1087-1094, 1985.

CASADO-CIMIANO, P.; GARCIA-ALVARES, J.A. Effect of mastitis on milk quality in Cantabria, Spain. Informe Agropecuário. v.13, p.14-18, 1988.

CHAVES, A.C.S.D. Estudo Do efeito do congelamento e do tempo de armazenamento sob refrigeração após o descongelamento nas propriedades funcionais, textura e proteólise do queijo mussarela. 1997. Tese (Doutorado) - Faculdade de Engenharia de Alimentos, Universidade de Campinas, Campinas, 1997.

COSTA, E.O.; BENITES, N.R.; MELVILLE, P.A.; PARDO, R.B.; RIBEIRO, A.R.; WATANABE, E.T. Estudo etiológico da mastite bovina. Revista Brasileira de Medicina Veterinária. v.17, p.156-158, 1995.

COSTA, E.O.; RIBEIRO, A.R.; WATANABE, E.T.; SILVA, J.A.B.; GARINO, J.F.; BENITES, N.R.; HORIUTI, A.M. Mastite subclínica: prejuízos causados e os custos de prevenção em propriedades leiteiras. Revista do Napgama. v.2, 1999.

CREAMER, L.K.; OLSON, N.F. Rheological evaluation of maturing Cheddar cheese. Journal of Food Science. v.47, p.362-636, 1982.

CUNHA, C.R.; SPADOTI, L.M.; ZACARCHENCO, P.B.; VIOTTO, W.H. Efeito do fator de concentração do retentado na composição e proteólise de queijo Minas Frescal de baixo teor de gordura fabricado por ultrafiltração. Ciência e Tecnologia dos Alimentos. v.22, n.1, 2002.

DOWNEY, W.K. Review of the progress of dairy science: flavour impairment from pre-and post-manufacture lipolysis in milk and dairy products. Journal of Dairy Research. v.47, p.237-252, 1980.

ERWIN, R.E.; RANDOLPH, H.E. Influence of mastitis on properties of milk. XI. Fat globule membrane. Journal of Dairy Science. v.58, p.9-12, 1975. 
FERREIRA, C.L.L.F.; MOURA, K.R.P.; BOTINHON, L.; COELHO, A.A.; SCHILLER, O.R. Avaliação tecnológica de cultura lácteas nacionais - produção de queijo Minas. Revista Instituto de Laticínios “Cândido Tostes”, v.47, 279-281, p.32-37, 1992.

FONSECA, L.F.L. Estudo da prevalência da mastite bovina e sua relação com práticas de manejo, higiene e terapia em fazendas produtoras de leite tipo B no Estado de São Paulo. 1992. Dissertação (Mestrado) - Escola Superior Luiz de Queiroz, Universidade de São Paulo, Piracicaba, 1992.

FONSECA, L.F.L.; SANTOS, M.V. Qualidade do leite e controle de mastite. São Paulo: Lemos Editorial, 2000.

FORSYTHE, S.J. Microbiologia da Segurança Alimentar. Porto Alegre: Artmed, 2002. 424p.

FOX, P.F. Proteolysis during cheese manufacture and ripening. Journal of Dairy Science. v.72, p. 1379-1400, 1989.

FOX, P.F.; LUCEY, J,A,; COGAN, T.M. Glicolysis and related reaction during cheese manufacture and ripening. Critical reviews in food science and nutrition. v.29, p. 237-253, 1990.

FOX, P.F.; MORRISSEY, P.A. Enzymes and food processing. In: BIRCH, G.C.; BLAKEBOROUGH, N.; PARKER, K.J. Enzymes and Food Processing. London: Applied Science Publishers Ltd., 1981. p. 213-238.

FURTADO, M.M. Manual prático da mussrela (pizza cheese). Campinas: Master Graf. 70p, 1997.

FURTADO, M.M.; LOURENÇO NETO, J.P.M. Tecnologia de queijos: manual técnico para produção industrial de queijos. São Paulo: Dimepar, 118p., 1994.

FURTADO, M.M.; SOUZA, H.M.; MUNCK, A.V. A fabricação do queijo Minas Frescal sem o emprego de culturas láticas. Revista do Instituto de Laticínios Cândido Tostes. p.1521, jan.-fev., 1980. 
FURTADO, M.M.; WOLFSCHOON-POMBO, A.F.; MUNCK, A.V.; SOUZA, H.M. Estudo conclusivo à respeito da fabricação do queijo Minas Frescal por diferentes processos. Revista do Instituto de Laticínios Cândido Tostes. p.13-16, mar.-abril., 1980.

GODKIN, A. Qualidade do leite ao redor do mundo: o papel da CCS. In: SIMPÓSIO INTERNACIONAL SOBRE QUALIDADE DOLEITE, 2.; ENCONTRO ANUAL DO CONSELHO BRASILEIRO DE QUALIDADE DO LEITE, 1., 2000, Curitiba. Anais... Curitiba: UFPR, 2000. p.9-20.

GRANDISON, A. Causes of variation in milk composition and their effects on coagulation and cheesemaking. Dairy Industries International. v.51, p.21-24, 1986.

GRANDISON, A.S.; FORD, G.D. Effects of variation in somatic cell count on the rennet coagulation properties of milk and on the yield, composition and quality of cheddar cheese. Journal of Dairy Research. v.53, p.645-655, 1986.

GRUFFERTY, M.B.; FOX, P.F. Milk alkaline proteinase. Journal of Dairy Research. v.55, p.609-630, 1988.

HAENLEIN, G.F.W.; SCHULTZ, L.H.; ZIKAKIS, J.P. Composition of proteins in milk with varying leucocyte contents. Journal of Dairy Science. v.56, p.1017-1024, 1973.

HARMON, R.J. Physiology of mastitis and factors affecting somatic cell counts. Journal of Dairy Science. v.7, p.2103-2112, 1994.

IDF, INTERNATIONAL DAIRY FEDERATION. Bovine Mastitis - definition and guidelines for diagnosis. Bulletin of International Dairy Federation. v.211, p.7, 1987.

IMM, J.Y.; OH, E.J.; HAN, K.S.; OH, S.; PARK, Y.W.; KIM, S.H. Funcionality and physicochemical characteristics of bovine and caprine mozzarella cheeses during refrigerated storage. Journal of Dairy Science. v.86, p.2790-2798, 2003.

INSTITUT OF FOOD TECHNOLOGISTS (IFT). Sensory evaluation guide for testing food and beverage products. Food Technology. v. 35, p.50-59, 1981. 
INSTITUTO ADOLFO LUTZ. Normas Analíticas do Instituto Adolfo Lutz, v.1, 3ed., São Paulo: IAL, 1985.

KASIMOGLU, A.; GÖNCÜOGLU, M.; AKGÜN, S. Probiotic white cheese with Lactobacillus acidophilus. International Dairy Journal. v.14, p.1067-1073, 2004.

KINDSTEDT, P.S. Mozzarela and pizza cheese. In: FOX, P.F. Cheese: chemistry, physics and microbiology. London: Elsevier Applied Publ. Science. p.337-362, 1993.

KINDSTEDT, P.S.; FOX, P.F. Modified Gerber test for free oil melted Mozzarela Cheese. Journal of Food Science, v.56, 1991.

KITCHEN, B.J. Reviews of the progress of dairy science: Milk compositional changes and related diagnostic tests. Journal of Dairy Research. v.48, p.167-188, 1981.

KLEI, L.; YUN, J.; SAPRU, A.; LYNCH, J.; BARBANO, D.; SEARS, P.; GALTON, D. Effects of milk somatic cell count on Cottage cheese yield and quality. Journal of Dairy Science. v.81, p.1205-1213, 1998.

KOSIKOWSKI, F.V. Cheese and fermented milk foods. $3^{\text {th }}$ ed.. Ann Arbor MI: Edwards bros. 1982

LANGENEGGER, B.; COELHO, N.M.; LANGENEGGER, C.H.; CASTRO, C.H.; CASTRO, R.P. Estudo da incidência de mastite bovina na bacia leiteira do Rio de Janeiro. Pesquisa Agropecuária Brasileira. v.5, p.437, 1970.

LANGONI, H.; DOMINGUES, P.F.; SILVA, A.V.; CABRAL, K.G. Aspectos etiológicos na mastite bovina. Revista Brasileira de Medicina Veterinária. v.20, p.204-210, 1998.

LEE, S.C.; YU, J.H.; JEONG, C.L.; BACK, Y.J.; YOON, Y.C. The influence of mastitis on the quality of raw milk and cheese. Korean Journal of Dairy Science. v.13, p.217-223, 1991.

LONDOÑO, M.M.D. Determinação das características de fabricação, padrões físicoquímicos, sensoriais e de comercialização do queijo Minas meia-cura e comparação com 
os queijos minas padrão e prato. 1998. Dissertação (Mestrado) - Universidade Federal de Lavras, Lavras, 1998.

LUCEY, J.A.; JOHNSON, M.E.; HORNE, D.S. Invited review: Perspectivas on the basis of rheology and texture properties of cheese. Journal of Dairy Science, v.86, p.2725-2743. 2003.

LÜCK, H. Control de la calidad de la industria lactologica. In: Robinson, R.K.. Microbiologia lactologica, v. 2, p.255-294. Zaragoza, Acribia, 1987.

LYNCH, J.M.; BARBANO, D.M. Indirect and direct determination of the casein content of milk by Kjeldahl nitrogen analysis: collaborative study. Journal AOAC International. v.81, p.763-774, 1998.

MA, Y.; RYAN, C.; BARBANO, D.M.; GALTON, D.M.; RUDAN, M.; BOOR, K. Effects of somatic cell count on quality and shelf-life of pasteurized fluid milk. Journal of Dairy Science. v.83, p.1-11, 2000.

MA, Y., BARBANO, D.M., SANTOS, M. Effect of CO2 addition to raw milk on proteolysis and lipolysis at $4^{\circ} \mathrm{C}$. Journal of Dairy Science. v.86, p.1616-1631, 2003.

MACHADO, E.C.; FERREIRA, C.L.L.F.; FONSECA, L.M.; SOARES, F.M.; PEREIRA JÚNIOR, F.N. Características físico-químicas e sensoriais do queijo Minas artesanal produzido na região do serro, Minas Gerais. Ciência e Tecnologia dos Alimentos. v.24, n.4, p.516-521, 2004.

MARINO, R.; CONSIDINE, T.; SEVI, A.; McSWEENEY, P.L.H.; KELLY, A.L. Contribuition of proteolytic activity associated with somatic cells in milk to cheese ripening. International Dairy Journal. v.15, p.1026-1033, 2005. In press.

MATIOLI, G.P.; PINTO, S.M.; ABREU, L.R. de; XAVIER, L.; TEIXEIRA, L.A.M. Influência do leite proviniente de vacas mastísticas no rendimento de queijo Minas Frescal. Revista Instituto de Laticínios “Cândido Tostes”, v.54, Supl.5, n.313, p.38-45, 2000.

MILLER, R.H.; EMANUELSSON, U.; PERSSON, E.; BROLUND, L.; PHILIPSSON, J.; FUNKE, H. Relationships of milk somatic cell counts to daily milk yield and composition. Acta Agriculturae Scandinavica. v.33, p.209-223, 1983. 
MITCHELL, G.E.; FEDRICK, I.A.; ROGERS, S.A. The relationship between somatic cell count, composition and manufacturing properties of bulk milk. 2. Cheddar cheese from farm bulk milk. Australian Journal of Dairy Technology. v.41, p.12-14, 1986a.

MITCHELL, G.E.; ROGERS, S.A.; HOULIHAN, D.B.; TUCKER, V.C.; KITCHEN, B.J. The relationship between somatic cell count, composition and manufacturing properties of bulk milk. 2. Composition of farm bulk milk. Australian Journal of Dairy Technology. v.41, p.9-12, 1986b.

MUIR, D.D. The shelf-life of dairy products: 2. Raw milk and fresh products. Journal of the Society of Dairy Technology. v.49, p.44-48, 1996.

MUNRO, G.L.; GRIEVE, P.A.; KITCHEN, B.J. Effects of mastitis on milk yield, milk composition, processing properties and yield and quality of milk products. Australian Journal of Dairy Technology. v.39, p.7-16, 1984.

MURPHY, S.C.; CRANKER, K.; SENYK, G.F.; BARBANO, D.M.; SAEMAN, A.I.; GALTON, D.M. Influence of bovine mastitis on lipolysis and proteolysis in milk. Journal of Dairy Science. v.72, p.620-626, 1989.

NATIONAL MASTITIS COUNCIL. Current concepts of bovine mastitis. Madison, WI: 4.ed., p.1-64. 1996.

NARIMATSU, A.; DORNELLAS, J.R.F.; SPADOTI, L.M.; PIZAIA, P.D.; ROIG, S.M. Avaliação da proteólise e do rendimento do queijo prato obtido por ultrafiltração. Ciência e Tecnologia de Alimentos, Campinas, v.23, suppl., dec., 2003.

NATZKE, R.P. Elements of mastitis control. Journal of Dairy Science. v.64, p.1431-1442, 1981.

NEEDS, E.C.; ANDERSON, M.; KIRBY, S. Influence of somatic cell count on the whipping properties of cream. Journal of Dairy Research. v.55, p.89-95, 1988.

O RENDIMENTO da fabricação de queijos: métodos para avaliação e comparação. <http://www.milknet.com.br/chrhansen/ed43_44.html>. Acesso em: 29 março 2005. 
OLIVEIRA, C.A.F.; MORENO, J.F.G.; MESTIERI, L.; GERMANO, P.M.L. Características físico-químicas e microbiológicas de queijo Minas frescal e Mussarela, produzidos em algumas fábricas de laticínios do Estado de São Paulo. Higiene Alimentar. v.12, n.55, p.3136, 1998.

OLIVEIRA, C.A.F.; FERNADES, A.M.; CUNHA NETO, O.C.; FONSECA, L.F.L.; SILVA, E.O.T.; BALIAN, S.C. Composition and sensory evaluation of whole yogurt produced from milk with different somatic cell counts. The Australian Journal of Dairy Technology. v. 57, n.3, p.192-196, 2002.

OLIVEIRA, J.S. Queijo: Fundamentos Tecnológicos. 2.ed., Campinas: UNICAMP, 1986.

OLIVER, S.P.; CALVINHO, L.F. Influence of inflammation in mammary gland metabolism and milk composition. Journal of Animal Science. v.73, Supl.2, p.18-33, 1995.

PAAPE, M.J., CAPUCO, A.V., GUIDRY, A.J. Morphology, function and adaptation of mammary cells in normal and disease states. Journal of Animal Science. v.73, Supl.2, p.117, 1995.

PAAPE, M. J.; WEGIN, W. P.; GUIDRY, A. J. Phagocytic defenses of the ruminant mammary gland. Advances Experimental Medical Biology. v.137, p.555, 1981.

PHILPOT, W.N.; PANKEY, J.W. Review of microorganisms that reportedly cause mastitis. In: Reserch Report N. Lousiania Hill Farm Experimental Station, Homer, LA. p.188, 1975.

PINTO, P.S. de A., GERMANO, M.I.S., GERMANO, P.M.L. Queijo Minas: Problema emergente da Vigilância Sanitária. Higiene Alimentar. v.10, n.44, p.22-26, 1996.

PIZAIA, P.D.; SPADOTI, L.M.; NARIMATSU, A.; DORNELLAS, J.R.F.; ROIG, S.M. Composição, proteólise, capacidade de derretimento e formação de "blisters" do queijo mussarela obtida pelos métodos tradicional e de ultrafiltração. Ciência e Tecnologia de Alimentos, Campinas, v.23, n.3, p.485-491, 2000.

POLITIS, I.; NG KWAI HANG, K.F. Effects of somatic cell counts and milk composition on cheese composition and cheese making efficiency. Journal of Dairy Science. v.71, p.17111719, 1988a. 
POLITIS, I.; NG KWAI HANG, K.F. Association between somatic cell counts of milk and cheese yielding capacity. Journal of Dairy Science. v.71, p.1720-1727, 1988b.

POLITIS, I.; NG KWAI HANG, K.F. Effects of somatic cell counts of milk composition on the coagulating properties of milk. Journal of Dairy Science. v.71, p.1740-1746, 1988c.

POUTREL, B.; CAFFIN, J.P.; RAINARD, P. Physiological and pathological factors influencing bovine serum albumin content of milk. Journal of Dairy Science. v.66, p.535-54, 1983.

PRATA, L.F. Fundamentos de Ciência do Leite. Jaboticabal: Ed. da UNESP, 1998.

RANDOLPH, H.E.; ERWIN, R.E. Influence of mastitis on properties of milk. X. Fatty acid composition. Journal of Dairy Science, v.57, p. 865-869, 1974.

ROGERS, S.A.; MITCHELL, G.E. The relationship between somatic cell count, composition and manufacturing properties of bulk milk. 5. Pasteurized milk and skim milk powder. Australian Journal of Dairy Technology. v.44, p.57-60, 1989.

ROGERS, S.A.; MITCHELL, G.E. The relationship between somatic cell count, composition and manufacturing properties of bulk milk. 6. Cheddar cheese and skim milk yogurt. Australian Journal of Dairy Technology. v.49, p.70-74, 1994.

ROGERS, S.A.; SLATTERY, S.L.; MITCHELL, G.E.; HIRST, P.A.; GRIEVE, P.A. The relationship between somatic cell count, composition and manufacturing properties of bulk milk 3. Individual proteins. Australian Journal of Dairy Technology. v.44, p.49-52, 1989.

ROWNEY, M.K.; HICKEY, M.W.; ROUPAS, P.; EVERETT, D.W. The effect of homogenization and milk fat fractions on the functionality of mozzarella cheese. Journal of Dairy Science. v.86, p.712-718, 2003.

RUBEZ, J. $\quad \mathrm{O}$ leite nos últimos 10 anos. <http://www.leitebrasil.org.br/artigos/jrubez_093.htm>. Acesso em: 31 janeiro 2006a.

RUBEZ, J. A era dos sólidos totais. <http://www.leitebrasil.org.br/artigos/jrubez_094.htm>. Acesso em: 31 janeiro 2006b. 
RYNNE, N.M.; BERESFORD, T.P.; KELLY, A.L.; GUINEE, T.P. Effect of milk pasteurization temperature and in situ whey protein denaturation on the composition, texture and heat-induced functionality of half-fat Cheddar cheese. International Dairy Journal. v.14, p.989-1001, 2004.

SANTOS, M.T.M.; PINHEIRO, A.J.R.; SOUZA, L.R.P.; OLIVEIRA, L.M. Queijo Minas: IIEfeito do tratamento térmico do leite sobre as características físico-químicas e sensoriais do queijo Minas. Ciência e Tecnologia de Alimentos, v.47, n.279-281, p.28-31, 1992.

SANTOS, E.S.; CARVALHO, E.P.; ABREU, L.R. Psicrotróficos: conseqüências de sua presença em leites e queijos. Boletim Sociedade Brasileira de Ciência e Tecnologia dos Alimentos. v.33, Supl.2, p.129-138, jul./dez., 1999.

SAS Institute. SAS ${ }^{\circledR}$ User’s Guide: Statistics. SAS Institute Inc., Cary, NC., 2004.

SCHÄLLIBAUM, M. Impact of SCC on the Quality of fluid Milk and Cheese. National Mastitis Council - Annual Meeting Proceedings. p.38-46, 2001.

SCHULTZ, L.H. Somatic cells in milk-physiological aspects and relationship to amount and composition of milk. Journal of Food Protection. v.40, p.125-131, 1977.

SENYK, G.F.; BARBANO, D.M.; SHIPE, W.F. Proteolysis in milk associated with increasing somatic cells count. Journal of Dairy Science. v.68, p.2189-2194, 1985.

SHIPE, W.F.; SENYK, G.F.; FOUNTAIN, K.B. Modified copper soap solvent extraction for measuring free fatty acids in milk. Journal of Dairy Science. v. 63, p. 93-198, 1980.

SIQUEIRA, J.F.M.; COELHO, D.T.; CHAVES, J.B.P.; FURTADO, M.M. Efeito da variação do teor de gordura do leite no rendimento do queijo minas padronizado. Revista Instituto Laticínios Cândido Tostes. v.41, p. 21-26, 1986.

SOMERS, J.M.; O’BRIEN, B.; MEANEY, W.J.; KELLY, A.L. Heterogeneity of proteolytic enzyme activities in milk samples of different somatic cell count. Journal of Dairy Research. v.70, p.45-50, 2003. 
STEFFERT, I.J. Compositional changes in cow's milk associated with health problem. In: MILKFAT FLAVOUR FORUM: SUMMARY OF PROCEEDINGS, 1993, New Zealand. Proceedings... New Zealand: New Zealand Dairy Research Institute, 1993. p.119-125.

SUNDHEIM, G.; BENGTSSON-OLIVECRONA, G. Isolated milk fat globule as substrate for lipoprotein lipase: study of factors relevant to spontaneous lipolysis in milk. Journal of Dairy Science. v.70, p.499-505, 1987.

TEXTURA da massa do queijo: fatores que a influenciam e parâmetros de controle (Parte I). Informativo HA-LA Biotec. Ano XI, n.9, maio/junho, 2002a. <http://www.milknet.com.br/hala.php>. Acesso em: 15 maio 2005.

TEXTURA da massa do queijo: fatores que a influenciam e parâmetros de controle (Parte II). Informativo HA-LA Biotec. Ano XI, n.70, julho/agosto, 2002b. <http://www.milknet.com.br/hala.php>. Acesso em: 15 maio 2005.

THOMAS, T.D.; PEARCE, K.N. Influence of salt and lactose fermantation and proteolysis in Cheddar cheese. New Zeland Journal Dairy Science Technology. v.16, p.253-259, 1981.

TRONCO, V.M. Manual para Inspeção da Qualidade do Leite. 2.ed., Santa Maria: Ed. da UFSM, 2003.

VALLE, J.L.E. do, CAMPOS, S.D.S; YOTSUYANAGI, K.; SOUZA, G. de Influência do teor de gordura nas propriedades funcionais do queijo tipo mozarela. Ciência e Tecnologia de Alimentos, v.24, n.4, p.669-673, 2004.

VERDI, R.J.; BARBANO, D.M.; DELLAVALLE, M.E.; SENYK, G.F. Variability in true protein, casein, nonprotein nitrogen, and proteolysis in high and low somatic cell milks. Journal of Dairy Science. v.70, p.230-42, 1987.

VERRUMA-BERNARDI, M.R.; DAMÁSIO, M.H. Análise descritiva de perfil livre em queijo Mozarela de leite de búfala. Ciência e Tecnologia de Alimentos, v.24, n.4, p.536-542, 2004.

WEAVER, J.C.; KROGER, M. Protein, casein, and non protein percentages in milk with high somatic cell counts. Journal of Dairy Science. v.60, p.878-881, 1977. 
WOLFSCHOON, P.A.F. Índices de proteólise em alguns queijos brasileiros. Boletim do Leite. Rio de Janeiro, v.51, n.661, p.1-8, 1983.

WOLFSHOON-POMBO, A.F.; CASAGRANDE, H.R.; LOURENÇO NETO, J.P. de M.; MUNCK, A.V. Alterações no queijo Minas frescal durante o período de armazenamento. Revista do Instituto de Laticínios Cândido Tostes. v.39, Supl.233, p.3-9, 1984.

YUNES, V.M. BENEDET, H.D. Desenvolvimento experimental de queijo fresco de leite da espécie bubalina. Ciência e Tecnologia de Alimentos, Campinas, v.20, n.3, p.285-290, 2000. 